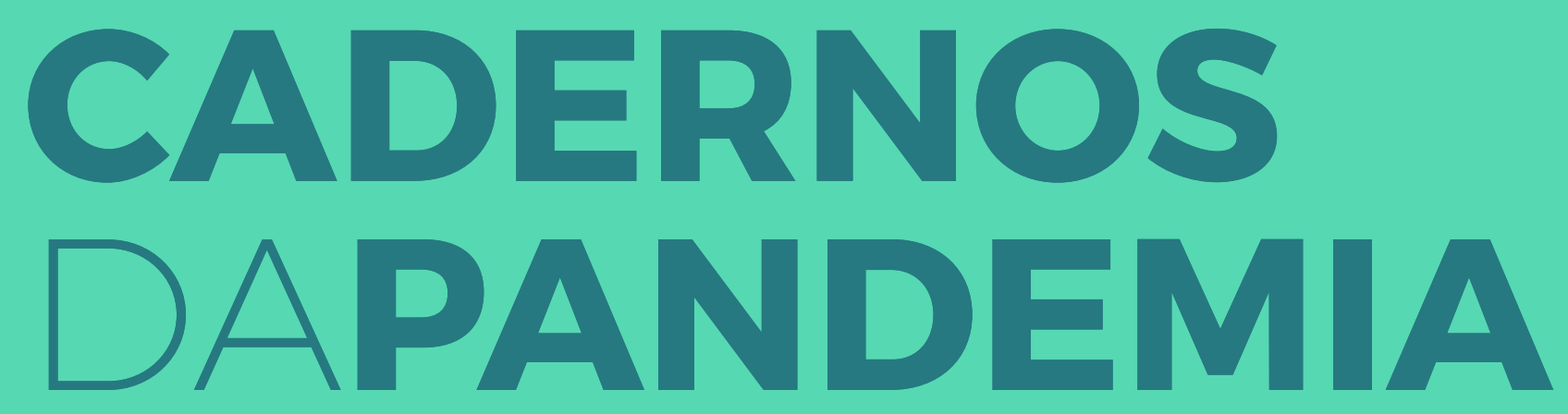

DO INSTITUTO DE SOCIOLOGIA DA UNIVERSIDADE DO PORTO

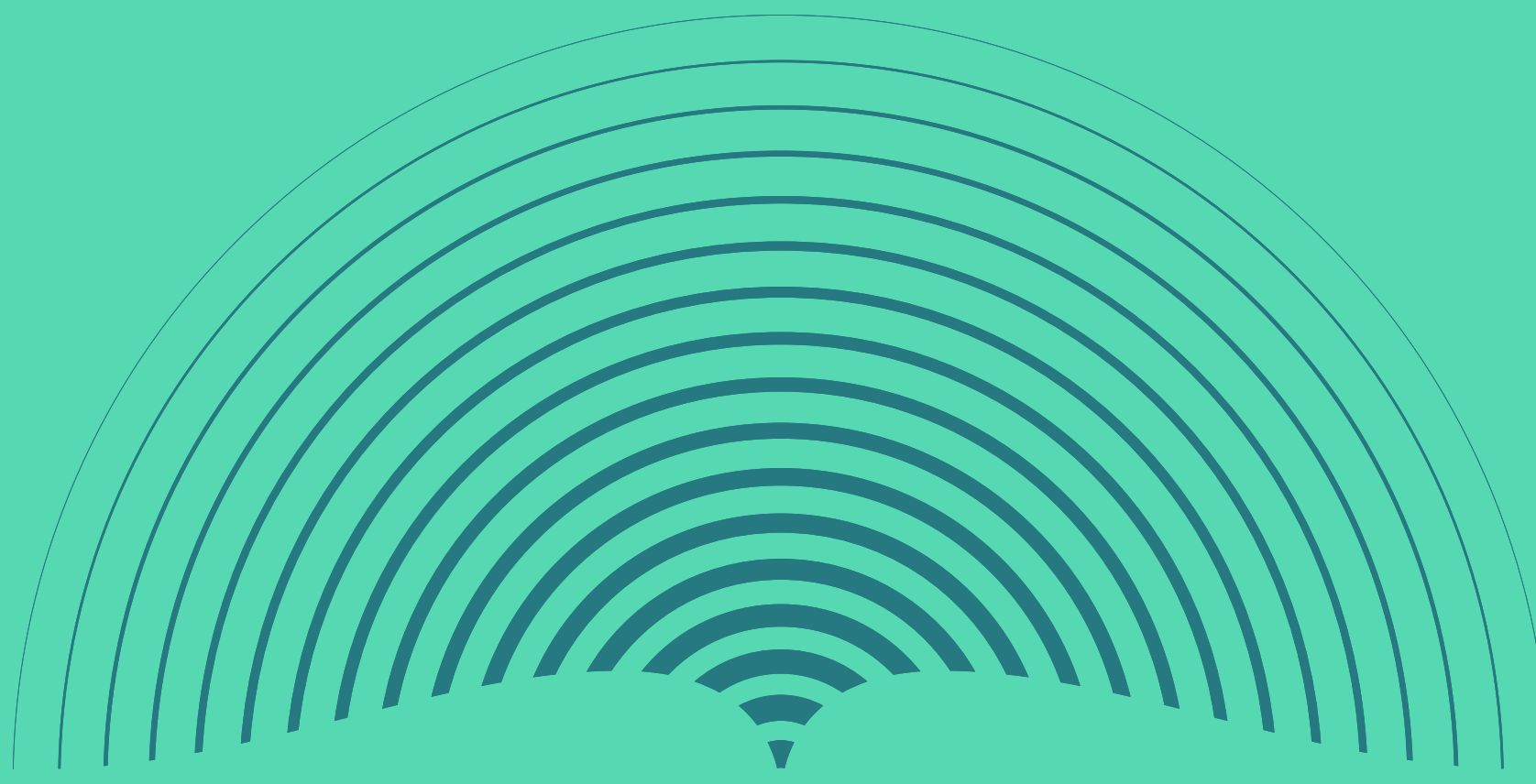

\title{
VOL. 5
}

EM SUSPENSO.

REFEXÕES SOBRE O TRABALHO ARTÍSTICO, CULTURAL E CRIATIVO NA ERA COVID-19. 

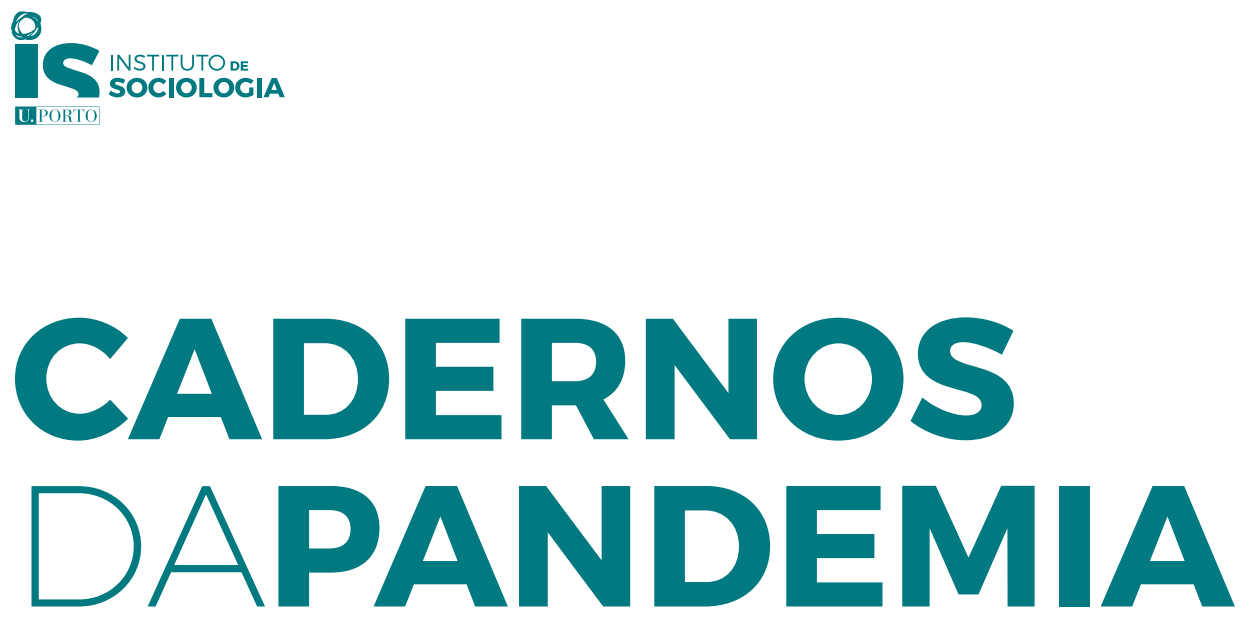

DO INSTITUTO DE SOCIOLOGIA DA UNIVERSIDADE DO PORTO

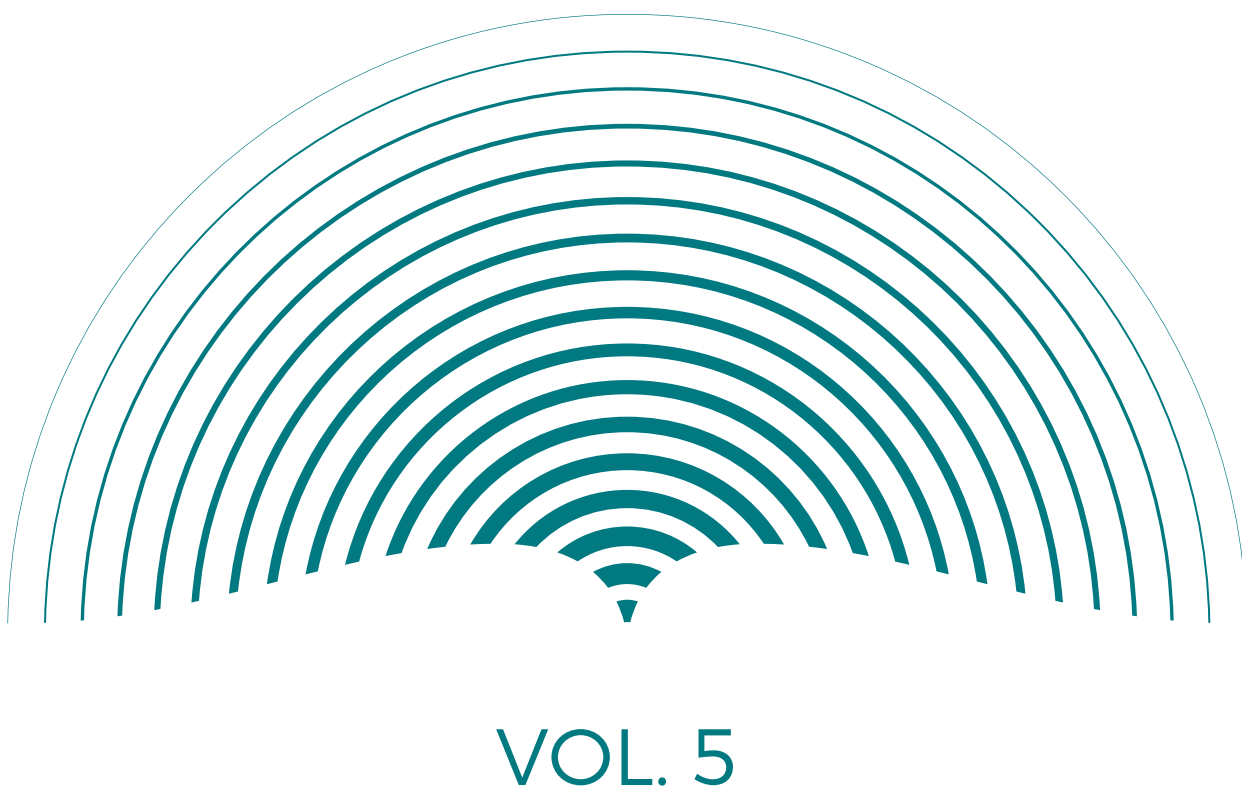

EM SUSPENSO.

REFEXÕES SOBRE O TRABALHO ARTÍSTICO,

CULTURAL E CRIATIVO NA ERA COVID-19. 


\section{Ficha Técnica}

Editor: Universidade do Porto. Faculdade de Letras

Título: Em Suspenso. Reflexões Sobre o

Trabalho Artístico, Cultural e Criativo na Era

Covid-19.

Organizadora: Tânia Leão

Autores: Amarilis Felizes, Capicua, José Soeiro,

Pedro Quintela, Lígia Ferro, Regina Guimarães,

Tânia Leão, Teresa Duarte Martinho, Vânia

Rodrigues, Vera Borges

Edição: Instituto de Sociologia da

Universidade do Porto

ISBN: 978-989-8969-61-3

Design Capa: Jorge Almeida

Paginação: José Teixeira

Data: outubro de 2020

Local de edição: Porto

Suporte: Eletrónico

Formato: PDF / PDF/A

Trabalho financiado pela Fundação para a Ciência e a Tecnologia no âmbito do Projeto UIDB/00727/2020 


\section{CADERNOS}

\section{CADERNOS DA PANDEMIA}

Esta publicação responde à exigência da relevância do conhecimento sociológico neste contexto de pandemia. É urgente analisar e debater a urgência, respeitando as formas, linguagens, métodos e protocolos do campo científico.

De repente, algo que os/as sociólogos/as há muito escreveram sobre as dimensões do risco e da incerteza à escala global, toma conta das nossas vidas sob a forma de uma pandemia. Contudo, este fenómeno pouco tem de catástrofe «natural». Na verdade, na multiplicidade de causas que a potenciam e na plêiade de consequências que se experimentam, sobressaem ativamente processos sociais. A relação predadora homem/ Natureza; a fragilidade de serviços públicos, nomeadamente de saúde, ameaçados por políticas austeritárias; o aprofundamento e a ampliação de desigualdades sociais entre países e dentro de cada Nação, aumentaram, em muito, a intensidade do flagelo e as vulnerabilidades humanas e sociais.

Sociólogos/as e cientistas sociais têm sido rápidos a construir conhecimento e a instaurar observatórios sobre a emergência. Estabelecem-se redes, lançam-se projetos, ativam-se cumplicidades.

O IS-UP faz a sua parte, abrindo caminhos de debate com estes cadernos.

O coordenador e a comissão executiva do IS-UP:

João Teixeira Lopes

Lígia Ferro

Idalina Machado 


\section{ÍNDICE}

\section{NOTA INTRODUTÓRIA}

Tânia Leão

\section{PARTE 1}

Cultura, Política, Trabalho: Profissionais Desocultados Procuram Direitos e Cuidados

Teresa Duarte Martinho

Pandemia e Cultura: (ainda) a urgência de um pensamento lento

Pedro Quintela e Vânia Rodrigues

Trabalho nas artes: breve guião para reconhecer direitos

Amarilis Felizes

\section{PARTE II}

O trabalho nas artes performativas na era COVID-19: da urgência ao potencial da mudança nas organizações e nas trajetórias de carreira artísticas

Vera Borges

Política e Trabalho no Sector do Cinema e Audiovisual em Contexto Pandémico: Velhas Tensões, Novos Protagonistas

Tânia Leão

A arte urbana na encruzilhada da pandemia: reflexões sobre o trabaIho cultural e artístico num segmento emergente

Lígia Ferro

"Recebo Verdi”. A cultura dos recibos verdes na cultura

José Soeiro

Algumas reflexões sobre isto de ser músico em tempo de pandemia (pequeno testemunho)

Capicua

O Jogo do Desconfinamento

Regina Guimarães 


\section{CADERNOS DAPANDEMIA

\section{NOTA INTRODUTÓRIA}

O irromper da pandemia originou uma crise sem precedentes no sector cultural - sem dúvida, um dos mais afetados pelo coronavírus. A precariedade intrínseca aos profissionais das artes e instituições culturais, a falta de visão estratégica para a cultura, a inexistência de políticas culturais estruturantes, o (incompreensível) desconhecimento, por parte das entidades competentes, sobre as condições em que se realiza a atividade laboral na área da cultura, o reacender da discussão sobre o estatuto de intermitência para a cultura, o movimento de união solidária entre profissionais, associações sindicais, políticos e ativistas pela sobrevivência e manutenção do sector, e contra os abusos laborais e de poder, todos estes fenómenos e vários outros, precipitaram-se recentemente. Nesse sentido, o objetivo deste volume consistiu em reunir contributos que refletissem sobre este tema, de indiscutível atualidade.

A presente publicação foi organizada em duas partes.

Num primeiro momento, podemos encontrar exercícios reflexivos que analisam os impactos da pandemia no sector artístico, cultural e criativo, segundo perspetivas mais amplas. As questões relacionadas com as políticas culturais desenvolvidas no país, a sua articulação com a regulamentação do trabalho, e as medidas de resposta (política e social) aos problemas colocados pela COVID-19, são as principais linhas que perpassam as abordagens aqui ensaiadas. São três os textos que integram esta secção. Teresa Duarte Martinho faz uma incursão pelo historial da política para a cultura em Portugal, incidindo nas matérias de regulamentação do trabalho artístico e cultural que foram reavivadas nos últimos meses. Pedro Quintela e Vânia Rodrigues mergulham na revisitação de um texto que ensaiaram para o jornal Público em abril de 2020, propondo um balanço crítico das propostas políticas que, no decurso dos últimos meses de atipicidade, foram anunciadas e implementadas, alertando para áreas cinzentas e domínios que têm permanecido menos visíveis. E Amarílis Felizes sugere-nos um breve guião orientador para o reconhecimento dos direitos laborais dos trabalhadores das artes, enquanto desconstrói alguns dos principais 'mitos' persistentes sobre o trabalho artístico.

A segunda parte deste volume reúne contributos que, sem desatender aos grandes eixos orientadores aflorados nos textos introdutórios e de enquadramento, concentram-se em áreas ou sectores específicos. As características do trabalho nas artes performativas e a forma como as políticas públicas e as organizações têm gerido a crise pandémica (e com que repercussões para a classe trabalhadora), é o tema aprofundado por Vera Borges. No texto de Tânia Leão, somos convidados a, à luz dos efeitos da pandemia, refletir sobre a evolução das políticas públicas para o cinema e audiovisual, para as tensões e lacunas subjacentes às mesmas, e para o lugar subalterno que o debate sobre o trabaIho tem assumido neste sector. Lígia Ferro, por sua vez, faz uma incursão pela temática da arte urbana e por alguns dos seus principais protagonistas, problematizando o impacto da pandemia nas suas condições de 


\section{CADERNOS}

trabalho presentes e perspetivas de carreira futuras. Uma análise rica e detalhada do conflito laboral entre um grupo de trabalhadores precários da Fundação de Serralves e da Fundação Casa da Música é o que nos propõe o texto de José Soeiro, que se apoia nestes episódios concretos para elaborar sobre a precariedade no sector cultural e sobre as iniciativas de reconhecimento da laboralidade que os mesmos suscitaram. Capicua oferece-nos um texto testemunhal, onde discorre sobre o impacto que a pandemia teve na sua prática artística e na desocultação das situações de precariedade no sector da música. Por fim, a secção termina com um poema de Regina Guimarães, um lamento que é também uma provocação.

O e-book não pretende ser exaustivo. A amplitude do sector cultural, artístico e criativo não é compatível com a análise crítica de do conjunto das áreas que foram afetadas pela COVID-19. As dimensões exploradas correspondem, por isso mesmo, aos âmbitos de interesse ou de atividade das autoras e autores convidadas(os). Do mesmo modo, o ritmo a que, nos últimos meses, têm surgido novos dados, exigiu um esforço contínuo de monitorização da informação (que, amanhã mesmo, sabemo-lo, poderá estar desatualizada).

Terminava com um sentido agradecimento a quem contribuiu para este volume dos Cadernos da Pandemia, com o empenho e o entusiasmo próprios de quem, numa época de aguda incerteza, privação e luta, é capaz de vislumbrar o potencial de mudança que, quase sempre, reside na tormenta. 


\section{CADERNOS DAPANDEMIA 0 INSTITUTO DE}

\section{PARTE 1}

\section{CULTURA, POLIITICA, TRABALHO: PROFISSIONAIS DESOCULTADOS PROCURAM DIREITOS E CUIDADOS}

\author{
Teresa Duarte Martinho*
}

\section{Resumo}

Tão aparentemente conhecida como realmente difícil de captar na racionalidade específica que a sustém, a vida precária de artistas e trabalhadores da cultura tem sido massiva e detalhadamente revelada em consequência da pandemia, que logo deixou à vista o aperto existencial de um segmento profissional desprovido de apoio para enfrentar o desemprego. Para compreender a vaga de movimentações por parte de profissionais, sindicatos e outros agentes, importa recuperar sinteticamente o historial da política para a cultura, em Portugal, em matéria de iniciativas de regulamentação do trabalho artístico e cultural, em particular nas duas últimas décadas. A COVID-19 redirecionou a tutela da cultura para a reabertura de um dossiê que se incumbiu há muito e foi transitando entre governos, que o têm deixado por resolver, observando-se desde março as implicações da pendência arrastada. A mobilização de sindicatos e plataformas coletivas proporcionou mais visibilidade a artistas e trabalhadores da cultura cujo discurso, também nos media, tem salientado por viva voz a incerteza, a pluriatividade e a falta de proteção social entre as principais caraterísticas do trabaIho nas artes e na cultura.

Palavras chave: cultura; política; trabalho; direitos.

\section{Introdução}

Incerteza, pluriatividade e falta de proteção social fazem parte das especificidades do trabalho nas artes e na cultura, que começou por captar a atenção indagadora das ciências sociais pelos desafios que as lógicas das ocupações artísticas lançam à teorização das profissões, da formação ao reconhecimento. A compreensão aprofundada destas dinâmicas particulares revelou-se especialmente esclarecedora também na reflexão acerca da economia do conhecimento, cuja configuração flexível e assente em networking foi, desde finais de 1970, importando e adaptando modalidades e valores do campo e do ethos artístico.

O traço mais forte de incerteza na vida laboral nas artes e na cultura ramifica-se noutras características, refletindo a junção, desde os anos 1990, do termo indústrias culturais com a expressão indústrias criativas: atividade dependente de procura instável, não regulada por nenhuma autoridade cultural e social; dificuldade de controlo da entrada no mercado de trabalho e da concorrência por lugares disponíveis; dedicação ao trabalho maioritariamente guiada pela vocação, autoexpressão e autonomia; desempenho simultâneo de atividades temporárias e diferenciadas, não exclusivamente relacionadas com o universo artístico e cultural; pagamento intermitente ou concentrado no tempo; trabalho sem remuneração, como condição de procura e angariação de oportunidades laborais, uma forma de vida que exclui os mais desfavorecidos económica e culturalmente; ausência de limites entre período de trabalho e horas livres, incentivada pela economia digital; tempo considerável investido em sociabilidade, física e virtual, para conseguir novos trabalhos, projetos e potenciar a reputação; redução provável do tempo dedicado às atividade de criação, pela necessidade crescente dos artistas gerirem a divulgação do seu trabalho e a comunicação com os espetadores, leitores e prosumers; tendência a não exteriorizar publicamente aspetos menos positivos, como descontinuidade, desgaste a insegurança social'.

Tão aparentemente conhecida de todos como realmente difícil de captar na racionalidade específica que a sustém, a existência pluriativa e precária

1 De um lote mais vasto de autores e contributos sobre o tema, salientam-se: Banks, 2017; Becker, 1982; Boltanski \& Chiapello, 1999; Boltanski \& Esquerre, 2017; Freidson, 1986; Gill \& Pratt, 2013; Greffe, 1999; Hesmondhalgh, 2008; Heinich, 2000; Menger, 1999; Sennett, 1998; Towse, 1992. 


\section{CADERNOS DAPANDEMIA SOCIOLOGIA}

de artistas e trabalhadores da cultura, excetuando o grupo diminuto dos que obtêm remunerações mais elevadas e regulares, havia já dado sinais abundantes das defesas frágeis, principalmente em contexto de crise, como ocorreu na conjuntura de recessão económica sucedendo à crise financeira mundial de $2008^{2}$. Volvidos doze anos, a pandemia significou um choque social de escala muito superior, convulsionando todas as dimensões da realidade, dos modos de trabalhar até aos protocolos de interação e sistemas de vigilância, passando pela reconfiguração da programação artística e cultural, em suportes e em calendarização. A COVID-19 surge, pois, como ilustração poderosa de um fenómeno social total, cuja complexidade predispõe a direcionamentos antagónicos e interdependentes. Ao mesmo tempo que instaurou o distanciamento, a desintegração e o recolhimento, tem vindo a atuar como mecanismo imparável de revelação detalhada das implicações dramáticas de regras estabelecidas nos moldes de vínculos laborais, como o recurso normalizado a formas ilegais de contratação e da falta de proteção social. Se até 2020 o carácter disfuncional das condições laborais foi vigorando, a COVID-19 expôs alargadamente o sufoco existencial de mais um segmento profissional, maioritariamente composto por trabalhadores independentes e freelancers, desprovido de apoio social para enfrentar o desemprego, uma vez encerrados teatros e salas de espetáculos, museus, cinemas, museus, bibliotecas, centros culturais, galerias de arte, ruas, monumentos e outros espaços que acolhem festivais, rodagens de filmes, feiras de artesanato.

Num dos primeiros inquéritos sobre as consequências da crise pandémica no sector cultural e artístico em Portugal, concluiu-se que o cancelamento de atividade correspondeu a uma perda de 2 milhões de euros, com $98 \%$ dos trabalhadores inquiridos registando atividades canceladas e $85 \%$ ficado numa situação de pobreza e desproteção

2 Garcia et al, 2018. social ${ }^{3}$. Um outro questionário apurava que cada espetáculo cancelado em resultado da pandemia equivalia a 18 artistas destituídos de rendimento ${ }^{4}$. Trata-se de um quadro tanto mais pesado quanto os encargos de quem emprega e recorre aos trabalhadores da cultura são quase inexistentes, excetuando a minoria dos que trabalham por conta de outrem e estão inseridos em regimes de carreiras. A precariedade dominante também em Portugal já fora evidenciada, numa vaga de estudos mais recentes, por um relatório elaborado, em 2015, pela UNI Europa - Media, Entertainment \& Arts, sindicato transnacional que representa funcionários, freelancers e contratados nestes setores: a maioria dos trabalhadores na produção de filmes e televisão eram empregados ao abrigo do estatuto de autoemprego (recibos verdes). Ainda que apresente as características de um contrato de trabalho, tal modalidade de prestação de atividade delega ao trabalhador a responsabilidade pelo pagamento da quase totalidade das suas contribuições de segurança social e a totalidade do prémio do seu seguro de acidentes de trabalho para trabalhadores independentes ${ }^{5}$.

Forças contraditórias têm reorganizado o setor, entre a divisão e desagregação geradas pelo isolamento e a aproximação e a convergência aceleradas pela urgência comum de subsistência, superação da crise profunda, preenchimento do vazio de trabalho e comunicação. Acelerou-se e intensificou-se a realização de diálogos e conversas em formato live, mais ou menos informais, nos websites institucionais e nas redes sociais; entrevistas nos media; manifestações coletivas de entreajuda e de reivindicação de apoio e mudança legislativa por parte do Estado, com a figura do artista sindicalista a alcançar mais visibilidade.

3 Inquérito por questionário promovido por Sindicato dos Trabalhadores de Espectáculos, do Audiovisual e dos Músicos - CENA-STE (https:/WwW.youtube.com/watch?V=85QU/5hyc/Q).

4 Inquérito levado a cabo pela Fundação GDA (Gestão dos Direitos dos Artistas) (Lusa in Público, 11.05.2020, "Covid19: um espectáculo cancelado equivale a 18 artistas sem rendimento").

5 Portela, 2018. 


\section{CADERNOS DAPANDEMIA $\mathrm{S}_{\text {SOCIOLLOGIA }}$}

A discussão intensificada da precariedade laboral entre profissionais da cultura relançou a atenção para a política estatal na área do trabalho cultural e da proteção social. Para compreender a vaga de movimentações no sector, por parte de profissionais, sindicatos e outros agentes, importa revisitar, em síntese, o historial da política para a cultura, em Portugal, em matéria de iniciativas de regulamentação do trabalho artístico e cultural, em particular nas duas últimas décadas e desde o surgimento da lei $4 / 2008$, de 7 de fevereiro, que aprovou o Regime dos contratos de trabalho profissionais de espetáculos. Servem de preâmbulo alguns apontamentos que contribuem para retratar o setor artístico e cultural, no discurso direto de um músico e representante sindical ${ }^{6}$.

\section{Por voz própria: afirmações, problemas e proposta de resolução}

\section{Trabalhadores, em vez de colaboradores}

"(...) quando começou esta situação [o alastrar da COVID-19 e a paragem do trabalho], umas das palavras que aparece recorrentemente na comunicação social é a palavra colaboradores. E nós, sejam músicos, técnicos, atores, performers ou escritores, começámos, repetidamente, a dizer os artistas, os técnicos, os trabalhadores da cultura, os profissionais são os trabalhadores da cultura, e essa palavra trabalhadores acho nunca foi tão repetida neste setor como agora."

6 Os extratos correspondem a declarações, que foram por nós transcritas e em alguns casos ligeiramente adaptadas, para melhor compreensão, de um representante da única entidade sindical dedicada a profissionais do setor em foco, o Sindicato dos Trabalhadores de Espectáculos, do Audiovisual e dos Músicos - CENA-STE, em vídeo produzido pela entidade referida (maio 2020, disponível em https:/ WWW. youtube.com/watch?V=85QU/5hyc/Q) e numa entrevista ao canal televisivo SIC Notícias (agosto 2020, disponível em https://beta.sicnoticias.pt/cultura/2020-08-10-Entrevista-Rui-Galveias).

\section{Atividades variadas, formação permanente, remuneração concentrada}

“(...) as medidas transversais [apoios ministeriais à situação de emergência] foram lançadas, mas não chegavam à maioria dos trabalhadores deste sector. A principal [razão] é a precariedade. [Os ministérios] foram alterando a forma de chegar aos trabalhadores a recibos verdes, porque há desde aquela pessoa que trabalhava há meses até aquela que trabalha 6 meses por ano e que é aí que concentra a sua atividade (...) Eu passo meses a trabalhar para fazer concertos, mas só faturo naquele momento [em que os realizo]. É aí que começa o problema da interpretação do que são os trabalhadores da cultura, sejam artistas ou técnicos. A maior parte está sempre em formação. Quando falamos de um técnico de som, um técnico de iluminação, um músico, um ator, estão sempre em formação e essa componente da nossa vida não é quantificada como trabalho, mesmo quando há contratos de trabalho, esse é o problema que nos falta resolver."

"Alguém dizia, num programa de antena aberta, que os artistas deviam também ter outros trabaIhos (...). No nosso sector, temos 3 ou 4 trabaIhos. Muitos trabalham, além da atividade como profissionais da cultura, noutras áreas, relacionadas ou não. Por exemplo, os músicos dão aulas, trabalham em 3 ou 4 orquestras, os atores fazem televisão, teatro e locução, dezenas de coisas durante o ano. Isso já é a nossa realidade (...) de pobreza e trabalho precário de dezoito horas por dia a fazer várias coisas ao mesmo tempo."

\section{Situação de emergência e soluções apontadas: reforço do orçamento para a cultura e alterações legis/ativas}

“(...) temos noção de que as pessoas estão numa situação de pobreza extrema, que uma grande parte dos trabalhadores estão sem trabalho e sem apoios, que a realidade do sector, que era profundamente precária, não estava preparada para esta situação e as que as estruturas 


\section{CADERNOS DAPANDEMIA $\underset{\text { SOCIOLOGIA }}{\text { INSTITUTO }}$}

também não (...) o presente precisa de um apoio social de emergência e de medidas de fundo e tem que se compreender em cada empresa, com as suas características, o que é preciso, para os trabalhadores não deixarem esta área de trabalho (...) por isso as soluções que defendemos há meses continuam a ser aquelas que têm que ser tomadas e o governo vai minimizando com estas linhas de apoio, nós conhecemo-las e percebemos logo as suas falhas (...) houve um conjunto de trabalhadores que por várias razões não estão identificados como trabalhadores da cultura e para a tutela não o são mas (...) sustentam muito do que é a atividade cultural e de entretinimento em Portugal.

[entrevistadora:] Está a falar de uma situação de emergência que é a que o setor vive desde o inicio da pandemia mas a cultura tem uma situação estrutural para resolver há anos, acha que vai ser desta vez que vão conseguir falar de um sistema de apoio para os artistas, de um sistema de saúde, dar segurança que seja mínima, esta atividade é irregular. Acha que é desta?

[entrevistado:] É fundamental, tal como o Ministério do Trabalho reconheceu num dado momento, no que o Ministério da Cultura acompanhou, garantir que os trabalhadores da cultura têm uma carreira contributiva e que lhes permita ter descontos de forma adequada e não os empobreça ainda mais, que é o que se passa com a maior parte das pessoas que estão a recibos verdes, e não só na cultura, permitir ter acesso normal ao subsídio de desemprego, à baixa médica e outros apoios. E isto é o que nós queremos para o futuro, que haja uma alteração de fundo na legislação, para que a todos os trabalhadores que são independentes possa ser garantida proteção, como a qualquer trabalhador.

(...) [importa vencer] o preconceito em relação ao contrato de trabalho no setor, por parte das entidades empregadoras, (...) [não faz sentido] a ideia de que os recibos verdes são a solução. Por outro lado, há que garantir que as estruturas, que trabalham em permanente prejuízo (...) tenham outro tipo de apoios. O reforço a sério do orçamento de Estado para a cultura, e defendemos pelo menos 1\%, e a alteração legislativa de modo a proteger estas pessoas e a garantir que tenham acesso a outro tipo de contratação são a solução"

\section{A expressão do recomeço e o que esperar das artes e da cultura}

"[na retoma do trabalho] quer-se abrir as portas dos teatros e num setor (...) que já está em sub-rendimento, sem poder funcionar normalmente, exige-se que [artistas e estruturas] tratem das medidas de higiene e da sua implementação, [supõe-se] que os artistas nem precisam de fazer testes mas [ao mesmo tempo] têm de ter camarins individuais; ou seja, as estruturas e os artistas que se aguentem com a sua própria realidade (...). Exigimos que seja o governo a garantir (...) que começamos a atividade com proteção e com qualidade.

Dizem que nós somos a alegria e podemos ser a força da retoma (...). Muitas vezes não vamos ser a alegria da retoma, vamos ser a catarse da retoma, vamos ser a expressão dos mais diversos sentimentos da retoma e desta situação de confinamento que vivemos. Mas não nos peçam para ser a cara alegre de uma coisa que está longe de estar a correr bem para a maioria das pessoas e dos trabalhadores e é nesse lugar que nós estamos todos."

\section{Missão por cumprir: um regime laboral específico para profissionais de espetáculos}

O tema do trabalho no sector cultural está entre os tópicos mais constantes nos programas dos governos constitucionais no capítulo da cultura, transitando de executivo para executivo. Desdobra-se na intenção de apoiar a formação e qualificação dos criadores e outros profissionais do sector e no reconhecimento da necessidade de definição de um estatuto profissional capaz de corresponder às especificidades dos criadores e intérpretes, através da criação de legislação laboral e proteção social adequada. Em 1976, o programa do I governo propunha-se definir um diploma sobre "o estatuto do 


\section{CADERNOS DAPANDEMIA SOCIOLOGIA}

profissional intelectual"7. Em 2019, o XXI governo, em vigor, atribuiu-se o desígnio de "regulamentação do Regime dos Contratos de Trabalho dos Profissionais de Espetáculos e a criação do Estatuto do Artista", com o propósito de enfrentar os "desafios específicos de um setor com forte incidência do trabalho de natureza precária e intermitente, nomeadamente, a ausência de proteção no desemprego e formas incipientes de proteção na velhice"8. O cumprimento parcelar de intenções e uma série de sucessivos adiamentos e impasses marcam a trajetória desta missão que o Estado se incumbiu há várias décadas, de que resultou um leque de iniciativas em resposta a problemas identificados que se encontra aquém das intenções expressas permanente e unanimemente. Uma abordagem detalhada e contextualizada das etapas desta incumbência, na década de 2000, pode encontrar-se no estudo Trabalho e Qualificação nas Atividades Culturais. Um panorama em vários domínios, publicado pelo Observatório das Atividades Culturais, que funcionou entre 1996 e 2013 e contou com o Ministério da Cultura entre os fundadores e associados ${ }^{9}$.

No XIV governo, em 1999, decidiu-se, por via de despacho conjunto dos Ministérios do Trabalho e da Solidariedade Social e da Cultura, formar uma equipa interministerial visando estudar e discutir questões relacionadas com o enquadramento laboral dos profissionais do espetáculo, promover a adaptação do regime de proteção social e apresentar propostas de reformulação normativa. A pertinência da iniciativa resultava, de acordo com os promotores, da "profunda alteração do cenário cultural português, devida a fatores ligados,

7 Programa do I governo constitucional.

8 Programa do XXI governo constitucional.

9 Gomes \& Martinho, 2009. A publicação, disponível em http://www.gepac.gov.pt/oac-1996-2013/gepac-oac/oac-obs-pesquisas.aspx, resultou de um estudo encomendado e financiado pelo Ministério da Cultura, "A Cultura em Portugal: Diagnóstico e Prospeção", que focou as problemáticas do emprego e exercício profissional no sector da cultura, entre outros temas. O estudo procedeu a uma releitura e atualização da pesquisa Políticas Culturais em Portugal, relativa ao período de 1985 a 1995, realizado também pelo Observatório das Actividades Culturais, publicado em 1998. nomeadamente, ao desenvolvimento de novas tecnologias, às políticas do Estado para o sector e às práticas culturais das populações, [que] impõe a necessidade de adequação da legislação aplicável às artes do espetáculo, em geral, e, em particular, no que respeita à redefinição do regime laboral e de proteção social dos profissionais do espectáculo"10. A atividade desta equipa não deixou vestígio, ficando por divulgar os seus resultados.

Em 2004, o XVI governo criou um grupo de trabalho destinado a identificar as principais questões do sector das artes do espetáculo nos planos jurídico-laboral e da formação profissional, para informar o estabelecimento de um regime laboral para os profissionais daquela área. Elaborou-se, então, um relatório que apresentou e discutiu possíveis cenários, aflorando aí, explicitamente, os questionamentos da tutela da cultura quanto à natureza e limitações das suas responsabilidades em matéria de regulação e regulamentação deste tópico, que remete igualmente para as políticas nas áreas do trabalho, segurança social e educação". Algumas entidades relacionadas com a coordenação dos regimes de segurança social e relações laborais tinham já reconhecido a necessidade de instituir sistemas que enquadrassem, de modo mais adequado, as particularidades do trabalho cultural e artístico, "encontrando as formas otimizadas de financiamento do sistema em que se divida a carga e o peso contributivo pelo beneficiário [da segurança social] que é o artista, pelo empresário que obtém o ganho gerado pela capacidade criativa do artista e, finalmente, pela coletividade que se enriquece culturalmente com a intervenção destes agentes operadores da humanização da vida"12.

Em 2008, a lei 4/2008, de 7 de fevereiro, aprovou o Regime dos contratos de trabalho dos profissionais de espetáculos, sendo objeto de contestação de todos os partidos da oposição, que a consideraram desajustada às dinâmicas do sector, por não abranger algumas profissões, não definir o regime

10 Despacho conjunto 73/2000 de 22 dezembro de 1999. Diário da República, II SÉRIE n.ำ17, 21 de Janeiro de 2000, 1306.

11 Silva, 2005.

12 Duarte, 2000. 


\section{CADERNOS DAPANDEMIA $\underbrace{0}_{\text {UPORTO }}$ SOCIOLOOGIA}

de segurança social, remetendo-o para um diploma específico (mantendo-se, assim, o sistema que remontava a princípios dos anos $80^{13}$ ) e excluir o trabalho em regime independente. A referida lei também deixava ausente a especificação dos serviços do Ministério da Cultura responsáveis pela inscrição dos "artistas de espetáculos" em registo próprio, conferindo um título profissional; remetia para um diploma próximo, porventura também pela divergência de perspetivas de entidades governamentais e associações profissionais quanto à fonte de maior autoridade para a certificação profissional14.

Face à exigência de rever o diploma anterior no espaço de quatro anos, operaram-se alterações que resultaram na lei 28/2011, de 16 de junho, com a redefinição do regime dos contratos de trabaIho dos profissionais de espetáculos e o estabelecimento do regime de segurança social aplicável. Passou a abranger perfis artísticos, técnicos e de mediação no sector das artes do espetáculo e do audiovisual e previu o regime de contrato a termo incerto, empregue para situações de intermitência. Instituiu o Registo Nacional de Profissionais do Sector das Atividades Artísticas, Culturais e de Espetáculos, tornando-o a condição de acesso a ações de valorização profissional e técnica promovidas pelo Estado e de emissão de certificado comprovativo de exercício da profissão. O diploma reservou a indicação do serviço responsável pelo registo para anúncio futuro, que só ocorreu em 2017, decorrida quase uma década após a lei 4/2008; cabe à Inspeção Geral das Atividades Culturais ${ }^{15}$ a coordenação do processo. As organizações profissionais do setor têm vindo a apontar a necessidade de rever e atualizar as listagens de profissões candidatáveis, para permitir "a utilização verdadeiramente capaz" deste instrumento ${ }^{16}$.

Em 2019, produziu-se uma nova alteração da lei 4/2008, de 7 de fevereiro, através da lei 22/2019, de 22 de fevereiro, estabelecendo o regime do

13 Decreto-Lei 407/1982 de 27 de setembro.

14 Gomes e Martinho, 2009.

15 Portaria 156/2017, de 21 de junho.

16 In Medidas para o setor das artes do espectáculo e do audiovisual (CENA-STE), disponível em http://www.cena-ste.org/. profissional de bailado clássico ou contemporâneo. Reconheceram-se, no diploma, alguns avanços e contributos para a qualificação do trabalho destes profissionais. Ao mesmo tempo, criticou-se não ter ainda reparado a falta de um regime de reformas específicas, capaz de atender às características de desgaste físico da profissão, exigindo tempo longo de formação e carreira ${ }^{17}$. Por outro lado, muito permanecia por corrigir e ajustar no regime dos contratos de trabalho dos profissionais de espetáculos, uma vez que a aplicação da lei 4/2008 dava mostras de conseguir perverter a finalidade de conferir alguma proteção ao exercício de funções com caráter intermitente ${ }^{18}$. Com o objetivo de impedir a sua desvirtuação e utilização abusiva, colocando os trabalhadores em condições (ainda) mais desfavoráveis, propôs-se a incorporação do diploma, com alterações, no Código do Trabalho e ainda a revisão de alguns artigos ${ }^{19}$. Casos concretos do recurso abusivo àquele diploma foram, além de avaliados judicialmente e apreciados por sindicatos da área, relatados e discutidos designadamente na tese $\mathrm{Na}$ boca de cena da (des)regulação do regime jurídico do contrato de trabalho dos profissionais do espetáculo e no relatório O estatuto profissional do artista. Regime laboral e de segurança social, promovido pela Fundação GDA-Gestão dos Direitos dos Artistas, ambos de $2018^{20}$.

\section{Presente e próximos capítulos: ações, propostas, reflexões}

Entre as consequências da COVID-19 está o redireccionamento da tutela da cultura para a reabertura

17 De acordo com parecer do CENA-STE, que criticou também o facto de, no caso da Companhia Nacional de Bailado, os bailarinos ficarem sujeitos automaticamente à reconversão profissional, a partir do ano em que completem 45 anos. In http://www.cena-ste.org/noticias/arquivo/2018-12/entry. htm/ ?ref=465\&b/og=noticias.

18 Neto, 2018; Portela, 2018.

19 Neto, 2018. O Bloco de Esquerda apresentou, em 2016, uma Proposta de Lei para retificar algumas disposições no Regime dos Contratos de Trabalho dos Profissionais de Espetáculos, aprovado pela lei n. $9 / 2008$, de 7 de fevereiro. 20 Neto, 2018; Portela, 2018. 


\section{CADERNOS DAPANDEMIA 0 SONSTIUTO DE}

de um dossiê que se incumbiu há muito e foi transitando entre governos, que o têm deixado por resolver, observando-se desde março as consequências drásticas desta situação. Em maio, o Ministério da Cultura anunciou a criação de um novo grupo de trabalho, formado por vários ministérios e associações profissionais, com a finalidade de atualizar o regime dos contratos laborais e de segurança social dos profissionais de cultura. Comprometeu-se, até ao final do ano, a apresentar uma proposta do estatuto do trabalhador intermitente da cultura, pedindo aos diferentes partidos "envolvimento e consenso" em torno da sua preparação ${ }^{21}$. Quanto às linhas de financiamento lançadas em resposta à situação de emergência, a responsável pela tutela destacou frequentemente ter conseguido executar "em três meses o que demora nove a ser realizado", algo "que nunca aconteceu na história da democracia" 22 . A ênfase na velocidade da atuação - ainda que o reforço continue a ser considerado uma resposta muito demorada, muito aquém das necessidades e envolvendo distorções na constituição dos montantes $^{23}$-, acaba por corroborar a capacidade de os governos intervirem com mais rapidez perante a reivindicação pública, quase universal, de apoio e intervenção estatal na proteção de todos os afetados pela crise e pela recessão antecipada ${ }^{24}$. Evidenciou-se ainda que o livre mercado, entregue a si mesmo, não constitui um mecanismo autoajustável e gerador de recuperação ${ }^{25}$.

Pela parte das entidades representativas de trabalhadores das artes e da cultura, recuperaram-se e reatualizaram-se cadernos antigos de propostas e reivindicações, procurando contribuir para operar uma viragem profunda e fundar um setor "sustentável e sustentado", em vez de assente em "esmolas

21 Lusa in Expresso, 26.06.200, "Ministra da Cultura pede consenso sobre estatuto do trabalhador intermitente".

22 Num reforço orçamental, referente a várias linhas de financiamento, cujo montante total previsto corresponde a 70 milhões de euros (Lusa in Expresso, 26.06.2020).

23 Felizes, 2020.

24 Banks, 2020

$25 \mathrm{lbidem}$. e subsídios"26. O objetivo de mudança visa: os contratos de trabalho, pedindo-se o cumprimento da lei laboral no setor artístico e cultural, incluindo a defesa dos contratos de trabalho sem termo para os que trabalham em permanência para uma entidade empregadora; a proteção social na doença, no desemprego e na parentalidade; o reconhecimento da descontinuidade da atividade como condição do acesso a remuneração contínua por via de subsídio de desemprego; o investimento na política cultural mediante o reforço do financiamento de estruturas artísticas e culturais. Vinca-se a perceção da interdependência destas medidas e áreas de intervenção, em particular da indissociabilidade entre o reforço do investimento público na cultura e o assegurar de condições laborais e sociais "dignas" como "garante para uma melhor cultura e produção artística no nosso país"27. Ressaltam nos diversos comunicados e manifestos apresentados por sindicatos e plataformas de trabalhadores culturais algumas nuances diferenciadoras, que é importante acompanhar e analisar no contexto das diferentes profissões e subáreas do setor cultural e criativo e também à luz do historial de intervenção das entidades de representação coletiva, que representa outro terreno reanimado em 2020. Reveste também relevância uma análise comparativa, que integre o conhecimento das dinâmicas de setores laborais com alguns traços, problemas e aspirações similares, como a investigação científica e o trabaIho de intervenção e serviço social ${ }^{28}$. No começo de outubro, passados quatro meses de negociações

26 Na expressão de um representante da Plataforma Convergência pela Cultura, constituída em 2020 (Lusa in Público, 01.09.2020, "Agentes culturais concentraram-se em Lisboa para 'brinde à ignorância da ministra'”').

27 In comunicado conjunto da APR-Associação Portuguesa de Realizadores, PLATEIA-Associação de Profissionais das Artes Cénicas e Sindicato dos Trabalhadores de EspectácuIos, do Audiovisual e dos Músicos - CENA-STE, apresentado ao governo, em julho. Disponível em https:/ www facebook. $\mathrm{com} /$ plateia.pac/posts/2605040809718777? th__ =K-R. A Plataforma Convergência pela Cultura apresentou também, em agosto, um extenso manifesto, disponível https://WWW. facebook.com/notes/converg\%C3\%AAncia-pela-cultura/ anexo-i-manifesto-da-plataforma-c\%C3\%ADvica-converg\%C3\%AAncia-pela-cultura/10159234642483488/.

28 Nicolas-le Strat, 2005. 


\section{CADERNOS DAPANDEMIA 2 INSTITUTO DE}

entre a tutela e várias entidades de profissionais do espetáculo e audiovisual, estas manifestavam descontentamento e preocupação por não verem incluída a "questão crucial da proteção social" nas próximas reuniões, acerca do registo dos profissionais e do regime laboral ${ }^{29}$, interpretando tal ausência como falta de vontade dos responsáveis governamentais de "mudar efetivamente o contexto insustentável de quem trabalha nestas áreas"30.

"Muitas vezes, não vamos ser a alegria da retoma, vamos ser a catarse, vamos ser a expressão dos mais diversos sentimentos da retoma e desta situação de confinamento que vivemos", dizia um artista sobre as expetativas de "cara alegre" na face e nas obras dos artistas e trabalhadores da cultura, na altura de recomeçar o trabalho - desde junho, pouco a pouco e por duração incógnita. Não é de excluir que o distanciamento destes trabalhadores da ideia de arte e cultura como baterias de alegria tenha também brotado da reflexão acerca do seu papel e propósitos, em tempo de colapso social e para além dele. Entre as lições a retirar da vida subitamente suspensa em 2020, já se alertou para a falta, no discurso do confinamento, da valorização do poder de crítica social através da linguagem simbólica da arte e da cultura, assolando o risco de erosão deste papel e a sua redução a fonte de entretenimento. Onde estará a arte como dissidência e desmontagem das respostas políticas à pandemia e das suas consequências nas nossas vidas? ${ }^{31}$

\section{Outubro de 2020}

*A autora segue as normas do Acordo Ortográfico da Língua Portuguesa de 1990.

\section{Referências bibliográficas}

Banks, M. (2017). Creative Justice. Cultural industries, work and inequalities. Rowman \& Littlefield Publishers.

Banks, M. (2020). The work of culture and C-19, European Journal of Cultural Studies, 1-7.
Becker, H. S. (1982). Art Wolds. University of California Press. Boltanski, L. \& Chiapello, Ė. (1999). Le nouvel esprit du capitalism. Paris: Gallimard.

Boltanski, L. \& Esquerre, A. (2017). Enrichissement: une critique de la marchandise. Paris: Gallimard.

Duarte, M. C. (2000). Nova Lei de Bases abre perspectivas. In Tamen, Teresa (coord.), Ser Artista em Portugal. Lisboa: Centro Nacional de Cultura, 117-119.

Felizes, A. (2020). Artes e cultura: fragilidades antigas, combatividade renovada, Le Monde Dip/omatique, julho, 6-7.

Freidson, E. (1986). Les professions artistiques comme défi à l'analyse sociologique, Revue française de sociologie, 27 (3), 431-443.

Garcia, J. L.; Lopes, J. T; Martinho, T. D.; Neves, J. S.; Gomes, R. T.; Borges, V. (2018). Mapping culture in Portugal: From incentives to crisis, International Journal of Cultural Policy", 24 (5), Advance online publication on 6 November 2016, 577-593.

Gill, R. \& Pratt, A. (2013). Precarity and cultural work in the social factory? Immaterial labour, precariousness and cultural work, ONCURATING, 16.

Gomes, R. Telmo \& Martinho, T. D. (2009). Trabalho e Qualificação nas Atividades Culturais: Um Panorama em Vários Domínios. Lisboa: Observatório das Atividades Culturais.

Greffe, X. (1999). L'emploi culturel à l'âge du numérique. Paris: Anthropos.

Heinich, N. (2000). Être Écrivain. Création et identité. Paris: la Découverte.

Hesmondhalgh, D. (2008). Cultural and Creative Industries. In Bennett, T. \& Frow, J. (eds.) The Sage Handbook of Cultural Analysis. London: Sage Publications, 552-569.

Menger, P. M. (1999). Artistic Labor Markets and Careers. Annual Review of Sociology, 25, 541-574.

Neto, J. (2018). Na boca de cena da (des)regulação do regime jurídico do contrato de trabalho dos profissionais do espetáculo. Tese de Mestrado em Direito das Empresas - Vertente de Direito do Trabalho. ISCTE - IUL.

Nicolas-le Strat, P. (2005). L'Experience de l'Intermittence Dans les champs de l'art, du social et de la recherche. Paris: L'Harmattan.

Portela, A. P. (2018). O estatuto profissional do artista. Regime laboral e de segurança social. Lisboa: Fundação GDA.

Sennett, R. (1998). The Corrosion of Character: Personal Consequences of Work in the New Capitalism. New York: Norton.

Silva, L. G. (coord.) (2005). Identificação das Principais Questões do Sector das Artes do Espectáculo (situação-jurídico laboral, acidentes de trabalho e doenças profissionais e formação profissional), Documento do Grupo de Trabalho do Ministério da Cultura.

Towse, R. (1992). The labour markets for artists, Richeche Economiche, 46: 55-74. 


\section{CADERNOS DAPANDEMIA SOCIOLOCI}

\section{PANDEMIA E CULTURA: (AINDA) A URGÊNCIA DE UM PENSAMENTO LENTO}

Pedro Quintela e Vânia Rodrigues*

\section{Resumo}

O artigo é elaborado a partir da revisitação de um artigo, escrito para o jornal Público em Abril de 2020, em que os autores ensaiavam - em pleno 'estado de emergência' - uma primeira leitura dos impactos da crise pandémica na esfera das artes, da cultura e das actividades criativas em Portugal. O propósito deste novo texto é fazer um balanço dessa observação, cinco meses volvidos, tentando identificar os desafios críticos que se perfilam e justapondo-os às respostas políticas que têm surgido. Para tal, apreciam-se genericamente algumas das medidas de resposta à crise pandémica no setor cultural e criativo (SCC) em Portugal entretanto anunciadas e implementadas, guiados por duas âncoras: i) a aceleração da 'agenda' da digitalização no universo das artes e da cultura; e ii) as transformações no domínio laboral, com o recrudescimento de exigências em torno do estatuto socioprofissional de artistas e demais profissionais da cultura, a par da criação ou reforço de mecanismos de protecção social e laboral especificamente pensados para o SCC. No segmento conclusivo do texto, relacionam-se estes dois eixos com o quadro geral de política cultural, a partir dos (escassos) documentos orientadores publicados, com o propósito de argumentar a favor da importância de um 'pensamento lento' sobre a cultura - metáfora para a necessidade de uma modernização criticamente informada e actualizada das políticas culturais em Portugal.

Palavras-chave: políticas culturais; digitalização; trabalho cultural e criativo; pandemia COVID-19.

\section{Retomando o fio à meada...}

No início de Abril, em pleno 'estado de emergência' provocado pela pandemia COVID-19, ensaiámos, num artigo para o jornal Público, uma primeira leitura dos impactos da crise pandémica na esfera das artes, da cultura e das actividades criativas em Portugal, na qual tentámos identificar alguns dilemas que nos pareceram ser críticos na resposta política à crise sanitária que vivíamos crise essa depressa tornada também económica e social (Rodrigues e Quintela, 2020). Nessa altura, encontrávamo-nos dominados por uma atmosfera de choque, e todo o comentário que não fosse de reacção imediata aos efeitos da crise sanitária parecia extemporâneo; ainda assim, empenhámo-nos em afirmar a urgência de um 'pensamento lento'. No essencial, foi nossa intenção sublinhar o paradoxo de que o nosso desconcerto e aflição não deveriam resultar em medidas e planos exclusivamente reactivos; o que procurámos defender foi que, mesmo num cenário de emergência como o que então vivíamos, era fundamental sermos colectivamente capazes de desenhar estratégias para um arco de tempo mais largo, evitando a adopção de medidas puramente ditadas pela urgência (the show must go on...), e de reequacionarmos o papel dos agentes artísticos e dos trabalhadores do sector cultural e criativo (SCC) na sua relação com o Estado e com toda a sociedade, adoptando novas lógicas de cooperação e de solidariedade, conforme sugerido por autores como François Matarasso (2020).

Cinco meses volvidos, e desafiados a contribuir para este volume dos Cadernos da Pandemia, revisitámos essa reflexão no sentido de dela fazer um balanço, necessariamente incompleto e provisório, dada a limitação do período de observação e a opção feita por uma visão panorâmica que impede uma consideração detalhada da heterogeneidade de situações e realidades que compõem o SCC. Mais do que, portanto, realizar uma análise fina e sistemática dos desenvolvimentos operados nesta ou naquela área, mantemo-nos fiéis ao nosso propósito inicial: tentar identificar os desafios críticos que se perfilam, justapondo-os às respostas políticas que têm surgido.

Nesse sentido, tentaremos apreciar algumas das medidas de resposta à crise pandémica no SCC entretanto anunciadas e implementadas em Portugal guiados por duas âncoras: i) a aceleração 


\section{CADERNOS DAPANDEMIA $\underset{\text { SOCLIOLOGIA }}{0}$}

da 'agenda' da digitalização no universo das artes e da cultura; e ii) as transformações no domínio laboral, com o recrudescimento de exigências em torno do estatuto socioprofissional de artistas e demais profissionais da cultura, a par da criação ou reforço de mecanismos de protecção social e laboral especificamente pensados para o SCC. No segmento conclusivo, procuraremos relacionar estes dois eixos com o quadro geral de política cultural, a partir dos (escassos) documentos orientadores publicados.

\section{A aceleração da 'agenda' da digitalização no universo das artes e da cultura}

Um dos sinais que se revelou desde o início da pandemia foi a extraordinária capacidade de reinvenção de muitas instituições culturais e agentes artísticos portugueses, que, de forma quase imediata, adaptaram conteúdos e formatos, organizaram campanhas, agregaram esforços: não só os arquivos se transformaram quase instantaneamente em conteúdos reproduzíveis, como novos e variados projectos se apresentaram em múltiplas plataformas digitais, sob o lema \#fiqueemcasa.

No entanto, a rapidez desse ajustamento que gerou uma formidável aceleração e algumas sobreposições - deve fazer-nos pensar. Como notávamos em Abril, é forçoso que questionemos a urgência que muitos criadores, estruturas e instituições artísticas e culturais sentiram em reagir e em se reposicionar, designadamente em termos da oferta de novos conteúdos e formatos: essa urgência não será, justamente, um sintoma do expansionismo económico que, em parte, nos conduziu até aqui? A hipótese de que, mesmo que involuntariamente, estivéssemos e possamos continuar a 'produtivizar' a pandemia é suficientemente arrepiante para, pelo menos, ponderarmos a oportunidade, o sentido e o real alcance das várias iniciativas de artistas e instituições culturais. Como refere Lorena G. Maldonado (2020), é difícil não ver neste movimento mais um sinal do hiper-produtivismo do SCC cuja adesão, consciente ou inconsciente, ao ethos do neoliberalismo tem sido apontada por inúmeros estudos sociológicos (ex. Menger, 2005; Ross, 2000, 2009; McRobbie, 2002, 2016; Gill e Pratt, 2008).

Importa, além disso, questionar a qualidade pedagógica dos recursos educativos que, de forma certamente voluntarista e bem-intencionada, foram sendo disponibilizados durante a pandemia por diversas instituições e equipamentos culturais. O relatório Os Monumentos Nacionais de Portugal e a Abertura ao Público: impactos decorrentes da COVID-19, recentemente publicado, demonstra que, apesar de todo o esforço em criar ou reactivar serviços online (visitas digitais, website, newsletter, uso intensivo das redes sociais Facebook, Instagram e Youtube, etc.), registaram-se inúmeras fragilidades e carências, tanto no plano dos recursos tecnológicos e infraestruturais, como da formação e capacitação dos próprios recursos humanos (Neves, 2020a: 40-41). ${ }^{32}$ Este diagnóstico vai, de resto, ao encontro de alguns dos aspectos apontados no Relatório Final (preliminar) elaborado pelo Grupo de Projeto Museus no Futuro, que foi também divulgado recentemente, e no qual se concede uma especial atenção às questões da digitalização, identificando um conjunto relevante de desafios e de oportunidades a este nível, entre os quais se incluem a digitalização de colecções e a promoção de um acesso mais aberto por parte dos cidadãos, o que convoca uma urgente reinvenção dos subsectores dos museus e do património cultural, designadamente ao nível das competências, estabelecendo novas parcerias (com universidades, mas também com empresas e profissionais ligados às chamadas indústrias culturais e criativas) e equacionando a criação de novos perfis de competências internos para a concretização deste desiderato (cf. Camacho, 2020).

A relevância da chamada transição digital no SCC não é uma questão recente, bem pelo contrário,

32 Note-se que este quadro não é especificamente português, conforme dão conta dois outros relatórios recentemente publicados, que evidenciam que, tanto na Europa, como noutros contextos internacionais, diversos foram os museus que, em contexto de confinamento, procuraram manter, através do recurso a novos suportes digitais, as relações com os seus públicos, apesar das frequentes restrições a nível técnico e tecnológico (cf. NEMO, 2020; UNESCO, 2020). 


\section{CADERNOS DAPANDEMIA SOCIOLOGIA}

sendo recorrentemente apontada em diversos relatórios e estudos. Refira-se, a título de curiosidade, que, há praticamente uma década (2011), este aspeto era já abordado num estudo encomendado pelo Ministério da Cultura francês, intitulado Culture \& Médias 2030. Prospective de politiques culturelles, sendo então considerado como um dos eixos decisivos de transformação do SCC. ${ }^{33}$ Ainda no ano passado, um relatório prospectivo sobre o SCC na União Europeia apontava a importância das novas tecnologias e do digital enquanto game changers (cf. KEA \& PPMI, 2019). É, contudo, evidente, que no contexto da pandemia, este tema readquiriu relevância e actualidade, marcando hoje as agendas políticas, nacionais e europeias, e sendo já visíveis os seus efeitos em vários programas de financiamento. ${ }^{34}$

Esta transição para o digital das programações artísticas e culturais deve ser adequada e estrategicamente pensada e preparada, o que, desde logo, exige recursos (técnicos e tecnológicos, mas também humanos, formando e capacitando profissionais) e um planeamento adequado. Importa ainda, por outro lado, atender às especificidades próprias dos diversos subsectores que integram o SCC. Se profissões e subsectores como os do património, museus, bibliotecas e arquivos, para além de outros que podemos associar às indústrias culturais e criativas (cinema, fotografia, multimédia, design, etc.), parecem reunir à partida melhores condições para realizar com maior facilidade e sucesso este processo de transição

33 Cf. http:/ www.culturemedias2030.culture.gouv.fr/

34 É o caso do programa Europa Criativa, cujo aviso de concurso Cross-border circulation and digital distribution of performing arts concedia grande importância às questões da distribuição digital (https://wWw.europacriativa.eu) calls/callsandresult/125); do concurso Cinemas as Innovation Hubs for Local Communities, que procurava apoiar "acções-piloto que permitam testar novos modelos e novas experiências de fruição de cinema" (https:/Www.europacriativa.eu/calls/callsandresult/124); ou ainda do Programa de Apoio a Projectos - Criação e Edição, da Direcção-Geral das Artes, que incentivava "o aprofundamento de novos modelos criativos que permitam o trabalho presencial, virtual ou misto e/ou que criem alternativas à apresentação pública presencial das obras artísticas"(https://www.dgartes.gov.pt/pt/sel-curso/3277). digital (cf. Bakhshi et al, 2019), já noutros, como as artes performativas (música, teatro, dança, circo, performance), profundamente marcados pela copresença entre artistas e público, este processo parece revelar-se bastante mais complexo e exigente. Elena Polivtseva (2020) alerta justamente para os limites de uma programação digital nas artes performativas, ao mesmo tempo que sublinha a necessidade desta transição para o digital surgir, tanto quanto possível, enquadrada no contexto da criação, ao invés de uma imposição política top-down que, num contexto de crise como o atual, tende a encarar, cada vez mais, a digitalização como uma resposta 'fácil' aos constrangimentos sanitários colocados pela pandemia. Neste contexto, parece, pois, impor-se a necessidade de uma reflexão que, por um lado, não considere de forme uniforme e unívoca todo o SCC, numa lógica de one size fits all, mas que, pelo contrário, o analise na sua heterogeneidade e pluralidade, ajustando assim as propostas de intervenção às características e especificidades de cada subsector.

Acresce que os consumos e as práticas de fruição cultural que utilizam novos suportes e meios digitais estão ainda longe de abarcar satisfatoriamente os diferentes segmentos de público. Efetivamente, desde há anos que investigadores na área dos média digitais alertam para os diversos constrangimentos socioeconómicos que condicionam o acesso aos suportes tecnológicos de acesso (o chamado digital divide), bem como assinalam as desigualdades existentes ao nível das competências para uma literacia dos média, tornando os indivíduos capazes de ler e interpretar estes tipo de conteúdos, sendo este último aspeto enfatizado sobretudo entre as gerações que não são nativas digitais (cf. Cardoso, 2013). Além disso, é sabido que os níveis de participação cultural mantêm-se muito débeis em Portugal, por comparação com os restantes Estados-membro da União Europeia, estando condicionados pelas baixas qualificações e níveis de rendimentos da população (Eurostat, 2019). Durante os anos da crise houve inclusivamente um decréscimo nos níveis de participação cultural, ainda longe de ser recuperado e que, provavelmente, sofrerá agora novo agravamento. 


\section{CADERNOS DAPANDEMIA $\underset{\text { SOCLIOLOGIA }}{0}$}

Num quadro de crise pandémica, que é também social e económica, assistiu-se ao reforço de algumas destas tendências, ampliadas pelas limitações de acesso a espaços e equipamentos que prestam 'analogicamente' serviços culturais às populações. Importa, assim, aprofundar o trabalho de mediação cultural que vem sendo realizado por várias instituições culturais em Portugal, dotando-as de recursos adequados e suficientes para que possam continuar a desenvolver processos de abertura e (re)conhecimento das artes e da cultura por diversos segmentos de público incluindo aqueles que estão, por razões diversas, menos receptivos a propostas de programação cultural e artística que privilegiem o digital. Simultaneamente, entendemos que a transição para o digital não deve ser desligada de um regresso a equipamentos culturais e espaços públicos urbanos - locais privilegiados de exercício da cidadania (UCLG Culture Committee, 2020) - sob pena de se estar a abandonar, senão mesmo a menosprezar, uma parte da população que não está hoje em condições de aceder e fruir dos conteúdos artísticos e culturais disponíveis ou a disponibilizar online. Estamos conscientes que são vários e complexos os desafios que aqui se colocam, desde logo do ponto de vista da gestão urbana, de modo a garantir que estes equipamentos culturais e espaços públicos continuam a ser locais de liberdade, abertura, inclusão e, além disso, claro está, locais seguros em termos sanitários, mas acreditamos que esta poderá ser uma oportunidade para as cidades trabalharem políticas culturais de proximidade, renovando a conexão entre o seu tecido artístico, cultural e educativo, as instituições culturais e os cidadãos.

Finalmente, e não menos importante, temos o desafio do modelo económico subjacente ao processo de digitalização das artes e da cultura, que torne este processo sustentável, o que novamente nos remete para a necessidade de capacitação adequada dos diversos subsectores do SCC, incluindo profissionais, para esta transição para o digital - especialmente os que estão menos vocacionados e pior 'apetrechados' para operar em 'ambientes' online _, exigindo um planeamento atempado e adequado. A este propósito, convirá acompanhar os próximos passos relativos à Directiva Europeia ${ }^{35}$ sobre os direitos de autor e direitos conexos no mercado único digital, recentemente aprovada, e que Portugal terá agora de transpor para a legislação nacional. A mesma foi criticada durante o seu debate e elaboração, e são cada vez mais sonoras as divergências entre os defensores do novo modelo e os que suspeitam que o regime de propriedade intelectual não contribuirá para a redução de desigualdades nem para a sustentabilidade do SCC. ${ }^{36}$

\section{Estatuto profissional, protecção social: velhas demandas, novas exigências}

Um outro sinal relevante, que emergiu logo desde o início da pandemia, prende-se com o modo activo e dinâmico como se discutiram no espaço público e mediático os impactos nefastos da COVID-19 nos mercados de trabalho ligados ao SCC, suscitando um curioso reavivar de certas 'velhas' reivindicações de cariz socio-laboral e levando mesmo o Governo a anunciar e, de forma mais gradual, a implementar diversas medidas que - têm insistido os responsáveis da tutela articulam a dimensão sectorial com a transversal. Nelas se incluem a revisão e enquadramento dos trabalhadores independentes (processo que tem sido repleto de incongruências, tendo mesmo merecido reparos da Provedoria da Justiça) e a "reorganização dos trabalhadores da Cultura/ reforma estrutural da Segurança Social e Revisão e classificação das profissões da Cultura", para tal tendo sido criado um Grupo de Trabalho entre o Ministério da Cultura, Ministério do Trabalho, Solidariedade e Segurança Social e Ministério das Finanças. A conclusão dos trabalhos anuncia-se para o final do corrente ano, e concentra um lastro de anos de expectativa, embora nos pareça prudente não fazer dele o Santo-Graal da cultura, tendo em conta o rol de fragilidades do sector, a

\footnotetext{
35 Cf. https:/Www.europarl.europa.eu/doceo/document/A-8. 2018-0245-AM-271-271_PT.pdf?redirect

36 A este respeito, cf. Simão (2020).
} 


\section{CADERNOS DAPANDEMIA $\underbrace{\text { SNSTITUTODE }}_{\text {OUPORTO }}$ SOCIOLOGIA}

sua crónica sub-orçamentação e a necessidade de manter e aumentar os apoios à criação.

Para além disso, o Governo tem anunciado um conjunto de medidas de "recuperação das atividades culturais" - abrangendo das artes performativas à criação literária e apoio às editoras e livrarias - cuja análise detalhada não cabe aqui mas que têm sido globalmente recebidas como insuficientes e assumem, por vezes, contornos pouco claros, como terá sido o caso das verbas 'realocadas' para a programação cultural em rede. À data de redacção deste texto, estão ainda por conhecer pormenores relativos à revisão do modelo de apoio às artes e à regulamentação da rede de teatros e cineteatros, que poderão constituir peças importantes para entender o sentido das políticas culturais pós-COVID-19.

Todas estas iniciativas e medidas governamentais têm sido acompanhadas de perto - e, em parte, correspondido, tantas vezes de uma forma reactiva -, por reivindicações e alertas vários lançados por um conjunto diversificado de organizações sindicais e de associações sócio-profissionais pré-existentes, mas também por um leque de movimentos informais que entretanto surgiram, para além de tomadas de posição, individuais ou colectivas, que, frequentemente, assumiram a forma de 'cartas-abertas' e de 'manifestos' publicados nas redes sociais ou na imprensa escrita. ${ }^{37}$ Se nem o tema nem o contexto de tumulto sectorial são recentes no nosso país (cf. Quintela, 2017), a crise pandémica terá favorecido uma mobilização com contornos inéditos no nosso país, generalizando e ampliando um debate que, até então, estava essencialmente circunscrito à esfera dos estudos académicos sobre políticas culturais e a alguns subsectores (ex. artes performativas, cinema e audiovisual) que evidenciavam uma maior capacidade de mobilização e acção

37 Há uma miríade de documentos disponíveis na Internet que atestam a diversidade e a contundência destas diversas iniciativas, das mais organizadas às mais dispersas. Por limitação de espaço, cingimo-nos a referir algumas delas: Acção Cooperativista, Intermitentes Porto-Covid, Convergência pela Cultura, movimentos que se juntaram à acção de CENA-STE, Plateia, entre outros. colectiva, em contexto associativo socioprofissional e/ou sindical. O foco nas questões laborais e na protecção social dos profissionais da cultura surge, assim, como um elemento comum a estas iniciativas, constituindo um alinhamento argumentativo que, de forma inédita, reforçou uma aliança estratégica raras vezes conseguida no passado em Portugal. A paragem total pode ter sido um factor determinante na disponibilidade para a participação individual, assim como a tomada de consciência progressiva do impressionante impacto da crise no sector. Mas nesta capacidade reforçada de organização colectiva teremos de considerar igualmente a renovação recente nos corpos dirigentes de algumas organizações socioprofissionais e sindicais, bem como o entusiasmo gerado pelo surgimento de novas plataformas representativas.

É de notar, no entanto, que os subsectores das artes performativas e do cinema e audiovisual continuam a ter um acesso privilegiado aos meios de comunicação social, daí resultando que o debate público e político se centre assimetricamente nestas duas áreas, de algum modo invisibilizando as reivindicações socio-laborais feitas por outros subsectores - veja-se, por exemplo, o caso dos trabalhadores da arqueologia, cujo sindicato denunciou ter sido excluído de todo este debate (cf. Barbosa, 2020) ou a actual composição das 'estruturas representativas do sector' auscultadas pelo já mencionado Grupo de 


\section{CADERNOS DAPANDEMIA $\underset{\text { SOCLIOLOGIA }}{0}$}

Trabalho interministerial ${ }^{38}$ dedicado ao Estatuto do Profissional da Cultura ${ }^{39}$. A não ser corrigido, este desigual tratamento do SCC, privilegiando determinadas áreas em detrimento de outras, terá provavelmente consequências futuras, não só por eventualmente deslegitimar politicamente algumas das medidas e instrumentos em elaboração, mas sobretudo por deixar a descoberto, do ponto de vista das políticas públicas, e num momento crítico como o actual, um conjunto muito significativo de sub-sectores, com impactos imprevisíveis no médio e longo prazo. ${ }^{40}$

Em sentido inverso, parece registar-se uma mudança relevante nos discursos reivindicativos

38 A informação disponível aponta a participação das seguintes nove entidades: a REDE, o Cena-STE, a Performart Associação para as Artes Performativas, a GDA (Gestão dos Direitos dos Artistas), a Plateia, a Acesso Cultura, a APR (Associação Portuguesa de Realizadores), a SPA (Sociedade Portuguesa de Autores) e o APTA (Agrupamento Português de Técnicos de Audiovisual). Note-se, assim, que, destas nove, pelo menos sete estão claramente focadas nas artes performativas (a maioria) e no cinema e audiovisual. É ainda de ressalvar que, apesar dos esforços feitos, não nos foi possível confirmar com rigor a constituição deste Grupo de Trabalho e modo de funcionamento, no que à auscultação sectorial diz respeito, uma vez que não existe documentação pública disponível com esta informação. A listagem das entidades participantes foi, portanto, elaborada a partir da leitura da imprensa e de contactos pessoais estabelecidos com representantes de algumas das estruturas associativas e sindicais presentes no Grupo de Trabalho.

390 estatuto em causa tem sido referido de formas muito diversas, pelo que não é certa que esta venha a ser a sua designação oficial. Referimo-nos brevemente a estas mutações na linguagem no ponto seguinte.

40 É importante notar ainda que esta capacidade reivindicativa apresenta traços bastante desiguais entre os diferentes subsectores que integram o SCC, verificando-se que, perante o actual contexto de pandemia, algumas áreas (ex. artes visuais ou design) têm permanecido praticamente em silêncio ou, quanto muito, optado por assumir lógicas de resposta à crise, mais proactivas ou reativas, de cariz puramente individual. Este tipo de reação altamente atomizada dos trabalhadores mantém, de resto, alguma coerência histórica com experiências anteriores de mobilização do SCC em torno de questões de âmbito sócio-laboral em que também já se verificavam este tipo de desequilíbrios na capacidade de mobilização e de organização colectiva dos diferentes subsectores artísticos, culturais e criativos (cf. Quintela, 2017). que emergiram logos nas primeiras semanas de pandemia, com repercussões relevantes na produção de novos discursos políticos e mediáticos tendentes ao alargamento dos sujeitos tradicionalmente considerados neste debate: do habitual foco nos 'artistas' parece estar a caminhar-se para um entendimento alargado - e bastante consensual - dos 'profissionais da cultura'. Com efeito, onde, há apenas dois anos, se lia, nos meios de comunicação social, acerca da "contestação dos artistas", lê-se hoje acerca "dos trabalhadores da cultura", ou, de forma ainda mais expressiva, dos "invisíveis da cultura"41. Este processo, bem-vindo na medida em que reconhece a heterogeneidade do SCC, não é, porém, isento de contradições, existindo um grande número de situações em que todo o universo de trabalhadores do SCC continua a ser reduzido aos 'artistas'42. A insistência no uso exclusivo dessa expressão poderá contribuir para uma visão simplista sobre um segmento de actividade sobre o qual imperam múltiplos equívocos, muitas vezes alimentados por discursos populistas, que ora reduzem o campo à infeliz categoria de 'subsídio-dependente', ora embarcam em retóricas inflamadas acerca do 'talento individual' e do 'empreendedorismo'. A linguagem utilizada pelos políticos e pelas instituições, públicas e privadas, constitui um indicador importante do lugar que reservamos às artes e à cultura na sociedade, pelo que não devemos desprezar as modulações de sentido que revelam. Acresce ainda que, como sabemos, o SCC ultrapassa hoje largamente a esfera das artes performativas e do cinema e audiovisual - os dois sub-sectores a que o Ministério da Cultura tem concedido uma maior atenção, como já vimos. Ora, na tomada de decisão política em matérias sócio-laborais, que

41 A utilização desta nova terminologia inicia-se, a 4 de Abril, com a publicação no Público de um artigo de opinião de Pedro Abrunhosa (2020) acerca dos "operários da cultura, invisíveis e silenciosos" que é retomada de forma explícita na Carta Aberta 'Os Invisíveis da Cultura (AA.VV, 2020), publicada no dia seguinte, seguindo-se, a partir de então, uma generalização do seu uso na imprensa

42 Para uma análise mais detalhada acerca dos debates em torno das designações dos profissionais da cultura, cf. Rodrigues (no prelo). 


\section{CADERNOS DAPANDEMIA 0 INSTITUTO DE}

lugar ocupam afinal a miríade de profissionais que estão ligados aos museus e galerias, ao património cultural, à literatura, às artes visuais, ao design ou à arquitetura, por exemplo?

O nosso propósito não é analisar as medidas de resposta à crise e a sua crítica per se, de forma exaustiva, mas sim ir assinalando 'zonas cinzentas' (aspectos que têm merecido menos atenção e problematização) e algumas tendências, mesmo que contraditórias, que possam vir a influenciar a modelação das políticas culturais. Com esse fito, centramo-nos agora noutro sinal que pode indiciar alterações importantes face ao que vinha sendo habitual no sector das artes e da cultura e que constituem, no nosso entender, reflexos - ainda que limitados - de uma maior determinação em centrar as 'lutas' da cultura em questões sociais de fundo: os direitos sociais, económicos e políticos dos cidadãos. É ainda demasiado cedo para sabermos se corresponderão a uma mudança mais profunda, mas é significativo o peso da dimensão laboral até nas designações de movimentos recém-constituídos ${ }^{43}$. Indagamos: poderão estas mutações nas concepções e modelos de organização colectiva dos trabalhadores do SCC caminhar no sentido de uma repolitização das lutas socio-laborais nesta área, quiçá invertendo os modelos tradicionais de formulação das políticas culturais (top-down), passando a ser erigidas também "de baixo para cima" (policy from below), como já intuíam, há alguns anos atrás, Greig De Peuter e Nicole S. Cohen (2015)? A insistência na condição de 'trabalhadores' poderá superar o finca-pé histórico do argumento da excepcionalidade da arte/ do artista que, não sem ambiguidades, validava a sua inscrição no sistema socioeconómico?

Num ensaio recente, Aurelien Catin corrobora alguns dos argumentos que já havíamos avançado no texto publicado em Abril (Rodrigues e Quintela, 2020): que, apesar de ser razoável, até certo ponto, insistir em algumas lutas "defensivas", a longo prazo a cultura não deve procurar

43 Se há apenas dois anos se auto-intitulavam "Comissão Informal de Artistas", agora são os "Intermitentes Porto Covid" ou a "Acção Cooperativista", por exemplo. isolar-se em regimes de excepção, mas antes relacionar as suas reivindicações com as de todos os que se encontram em situação de vulnerabilidade social e precariedade. Trata-se, segundo o autor, de "desenvolver novas estratégias, mais radicais e (...) mais políticas.” (Catin, 2020:11)44. Neste ponto, Catin, tal como Max Haiven, não poderia ser mais claro: trata-se de fazer uma escolha entre os artistas continuarem a defender-se enquanto artistas (e intermediários culturais), tendo por base o argumento de que são uma "espécie de unicórnios do capitalismo que têm de ser salvos" (Haiven:2020) ${ }^{45}$ ou optar, em alternativa, por construir uma causa comum com os restantes trabalhadores semi-abandonados pelo capitalismo. Já o havíamos notado no texto de há uns meses, e mantemos as razões para desconfiar que uma resposta sectorial aos problemas de precariedade e baixos padrões remuneratórios prevalecentes no SCC venha a ser uma resposta fraca e de curto prazo. Apesar de bastante diferentes nos seus pressupostos, outros autores também acompanham esta linha de pensamento. É o caso de Justin O'Connor (2020), por exemplo, que sublinha ser determinante reconhecer que a condição material de precariedade que, historicamente, atravessa estruturalmente boa parte do SCC, é hoje partiIhada com muitos outros trabalhadores ${ }^{46}$, e convida-nos a questionar os argumentos que estão, na actualidade, a estruturar os apoios à cultura, tanto do lado da sua reivindicação como da concessão.

Não nos parece que se trate apenas da velha distinção entre táctica e estratégia, mas também de uma leitura crítica das transformações que uma crise com a dimensão da actual pode favorecer, no quadro de uma eventual revalorização do papel do Estado na sociedade. Aliás, uma das hipóteses de transformação que tem marcado alguns debates - ainda claramente marginais - em diversos países está relacionada com o crescente interesse

\footnotetext{
44 Tradução nossa.

45 Idem.

46 Atente-se, neste ponto, à particularmente interessante análise que Catin (2020) faz das aproximações e distanciamentos entre as lutas do SCC e o movimento dos Gilets Jaunes em, França por exemplo.
} 


\section{CADERNOS DAPANDEMIA $\underset{\text { SOCLIOLOGIA }}{\mathrm{INSTITUTO}}$}

por mecanismos de 'rendimento básico incondicional'. Diversos nas designações e formulações (cf. Merrill et al, 2019), estas propostas têm características que as tornam interessantes quando as relacionamos com a natureza e as especificidades do trabalho artístico, designadamente ao dissociarem 'trabalho' de 'emprego'. Não nos é possível, no contexto deste artigo, dar conta da multiplicidade de conexões que podem estabelecer-se entre estes dois tópicos, mas não queremos deixar de assinalar que seria muito interessante que a discussão em torno das políticas culturais e das condições da prática e da fruição artísticas se inscrevesse nestes debates mais amplos, por várias ordens de razões: i) esse interesse seria coerente com o reconhecimento da transversalidade de alguns desafios e problemas que enfrenta o SCC (como a precariedade ou a intermitência laborais) ${ }^{47}$; ii) no plano teórico, este é um debate que encontra ressonâncias profundas em questões tradicionalmente fundamentais para os agentes do campo: as questões de autonomia e independência; e, iii) estes debates convocam diversas possibilidades de transformação dos sistemas actuais de financiamento das artes, que muitos já vêem como caducos. Por último, poderia chegar-se ao ponto, mais especulativo, de argumentar que a cultura é o lócus perfeito para estas discussões que seriam uma forma de expiar as culpas pela alegada acomodação mútua entre capitalismo e os modos do trabalho artístico ${ }^{48}$, e de voltar a ser o lugar de crítica social.

47 Com efeito, apesar das suas especificidades e particularidades, o universo amplo de profissionais ligados às artes, cultura e indústrias culturais e criativas, enquadra-se, na realidade, no que autores como Andrew Ross (2008, 2009), por exemplo, têm vindo a designar de uma "nova geografia do trabalho".

48 Como têm notado, entre outros, Menger (2005), Ross (2000, 2009) e McRobbie (2002, 2016).

\section{Políticas culturais em Portugal: o desafio de uma modernização criticamente informada e atualizada}

Os dois aspectos que abordámos aqui - a aceleração da 'agenda' digital e as velhas demandas e novas exigências em torno das condições de trabalho e de protecção social do SCC - estão longe de esgotar os desafios que se perfilam para as políticas culturais, num cenário de prevalência e incidência do COVID-19 e, sobretudo, no pós-pandemia, mas não deixam de constituir pontos de pressão no sentido da sua modernização.

De facto, na Europa, as políticas culturais têm demonstrado grande resistência e rigidez, por exemplo, no modo como têm vindo a abordar as questões relacionadas com os processos de transição para o contexto digital e a definição de propostas adequadas e ambiciosas, capazes de responder aos dilemas e desafios, múltiplos e diversificados, que a 'agenda' digital hoje coloca (Martel, 2020). Isto parece-nos ser particularmente evidente em Portugal, onde a matriz de concepção e estruturação das políticas públicas, historicamente devedora do modelo francófono, é ainda profundamente tradicionalista, e cujas respostas estão, para além disso, de algum modo bloqueadas pela falta de recursos humanos e financeiros, evidenciada na tendência de desinvestimento público no sector que se vem registando desde 2012 (cf. Neves, 2020b; Garcia et al, 2016). Acresce que o olhar do Ministério da Cultura está hoje muito condicionado pela discussão e contestação públicas, que, como já vimos, encerra enviesamentos significativos do ponto de vista da representatividade de vários subsectores e profissões. É difícil, portanto, afirmar que este possa ser um momento oportuno para repensar a orientação das políticas públicas para a cultura em Portugal, investindo numa reflexão estratégica acerca dos desafios, dilemas e prioridades a assumir no processo de transição digital do SCC. E ainda mais arriscado imaginar que, no contexto atual, se possa estar perante uma oportunidade para relançar, agora com bases mais sólidas e com menos buzzword, a 'agenda criativa' em Portugal (Quintela e Ferreira, 2018), reequacionando medidas e instrumentos de 


\section{CADERNOS DAPANDEMIA SOCIOLOGIA}

apoio que se dirijam de facto às estruturas (empresas, cooperativas, associações) e aos profissionais deste sector, procurando assim criar condições mais favoráveis à fase de retoma pós-pandemia, ainda em data incerta.

Este nosso cepticismo encontra eco, por exemplo, nas referências genéricas, porque desprovidas de quaisquer desenvolvimentos específicos no que diz respeito ao SCC, tanto relativamente à questão do digital, como no que toca às áreas artísticas e culturais, no recente documento Visão Estratégica para o Plano de Recuperação Económica de Portugal 2020-2030 (Silva, 2020). Na leitura do referido plano (um dos poucos documentos públicos já disponíveis com pistas acerca do que poderão vir a ser as orientações estratégicas pós-COVID-19, designadamente no que diz respeito à utilização quer dos apoios extraordinários de recuperação económica dos impactos da pandemia, quer do próximo quadro plurianual de fundos comunitários, que vigorará entre 2021 e 2027), encontramos razões para acreditar que, a despeito das mutações discursivas que fomos assinalando ao longo deste texto, ainda persiste em Portugal uma visão da cultura que a perspectiva essencialmente enquanto uma 'amenidade' urbana, sem peso político, económico e social próprio. Com efeito, e apesar de a Ministra da Cultura se regozijar com o 'destaque' dado à área no Plano de Recuperação Económica de Portugal 2020-2030 (ex. Salema, 2020; Halpern, 2020), uma análise dos elementos disponíveis revela, contudo, que, à excepção de esparsas referências a investimento em I\&D para fileiras especializadas do sub-sector do património, a maioria das propostas revela uma continuidade das políticas culturais de pendor infraestruturalista: se já não se constroem, como no passado, equipamentos, estabelecem-se redes: rede nacional de teatros e cineteatros, rede nacional de arte contemporânea, rede de residências artísticas, rede de eco-residências artísticas... Acresce ainda que quase todas as medidas elencadas neste plano surgem justificadas como elementos 'dinamizadores do território'. Ou seja, o investimento no SCC é, uma vez mais, politicamente legitimado pela 'agenda' dos impactos (na inclusão social, no turismo, na economia, e agora também, na correcção das assimetrias regionais). Nada de novo, portanto. Parecem retomar-se, assim, alguns dos 'velhos' argumentos económicos senão mesmo economicistas - e de forte pendor instrumental que, conforme inúmeros cientistas sociais têm evidenciado (ex. Ufalino, 1996; Belfiore, 2002; Miller e Yúdice, 2002; McGuigan, 2005), vêm sendo determinantes nas últimas décadas na legitimação do investimento público em cultura (e com os resultados que conhecemos, acrescentaria algo ironicamente O'Connor, no texto já mencionado), que são, desta feita, posicionados bem no centro do debate sobre políticas públicas para a cultura em Portugal - do qual, aparentemente, nunca saíram...

As sinergias entre áreas de intervenção pública podem ser, efectivamente, incentivadas pelas políticas culturais, mas fazê-lo implica um conjunto de condições que não vemos, para já, asseguradas: desde logo, a mobilização de recursos suficientes para apoiar as iniciativas existentes ou latentes em diversos pontos do território; uma disponibilidade para repensar as formas de governança (o facto de o Estado surgir neste plano como grande organizador da oferta cultural carece, em nossa opinião, de contraponto em matéria de fortalecimento e confiança nas organizações da sociedade civil, mas também denota uma incapacidade de interpretar qual é hoje o papel da iniciativa privada no SCC e quais os mecanismos públicos adequados neste quadro) e, sobretudo, só é aceitável na medida em que for complementar a uma política cultural ancorada no valor intrínseco da cultura e na sua indispensabilidade social - uma dimensão-chave que, no quadro da crise pandémica, tem sido, de resto, enfatizada por alguns relatórios recentes (cf. por ex. Kern. 2020; Montalto et al, 2020; UCLG Culture Committee, 2020). A ideia de que a cultura é uma aposta estratégica para o futuro, um "pilar estratégico, com um programa autónomo" conforme declarou Graça Fonseca ao Jornal de Letras, Artes e Ideias (Halpern, 2020: 7), não encontra, sequer, amparo no próprio documento. Com efeito, no quadro ${ }^{49}$ que

49 Cf. Silva, 2020: 71 - Figura 10. 


\section{CADERNOS DAPANDEMIA $\longrightarrow$ INSTITUTODE}

estabelece a relação entre os eixos estratégicos e os objectivos do Plano, a área da "Cultura, Serviços e Turismo" é a única que não tem uma relação directa com nenhum dos nove objectivos. Este é um 'pormenor' que não nos deixa esperançados e que confirma uma tese explicativa do estado depauperado das políticas culturais em Portugal: a de que a cultura se mantém como um domínio de política pública estruturalmente fraco, com muitas dificuldades em se afirmar face a 'agendas' que se destacam pelo seu maior poderio político, económico e mediático (Ferrão: 2015), e com um peso relativamente baixo na 'agenda' macropolítica (Barbieri: 2012).

Insistimos, por isso, na urgência de, no quadro de uma crise que se perspetiva longa e profunda, apostar num pensamento lento sobre cultura em Portugal - metáfora para a necessidade de contrariar as políticas culturais continuativas, resultado de processos mais cumulativos e reactivos do que transformadores, pouco críticos e escassamente actualizados.

Porto, 1 de Setembro de 2020

Os autores não seguem as normas do Acordo Ortográfico da Língua Portuguesa de 1990.

\section{Referências bibliográficas}

Abrunhosa, P. (2020). A solidão dos que juntam multidões, Público, 4 de Abril, 16.

AA.VV. (2020). Carta aberta: Os "invisíveis" da Cultura”. Público, 5 de Abril, 28.

Bakhshi, H.; Djumalieva, J.; Easton, E. (2019). The Creative Digital Skills Revolution. Londres: Creative Industries Policy and Evidence Centre / NESTA. Disponível em https://www.pec. ac.uk/assets/publications/The-Creative-Digital-Skills-Revolution-the-PEC-and-Nesta-24-Oct-2019.pdf.

Barbieri, N. (2012). Por qué cambian las políticas públicas? Una aproximación narrativa a la continuidade, el cambio y la despolitización de las políticas culturales - El caso de las politicas culturales de la Generalitat de Catalunya (1980-2008). Tese de Doutoramento. Barcelona: Universitat Autònoma de Barcelona.

Barbosa, R. (2020). Apoiosinvisíveis: a situação dos Trabalhadores de Arqueologia, Público, 20 de Agosto. Disponível em https:// www.publico.pt/2020/08/20/culturaipsilon/opiniao/apoios-invisiveis-situacao-trabalhadores-arqueologia-1928672
Belfiore, E. (2002). Art as a means of alleviating social exclusion: Does it really work? A critique of instrumental cultural policies and social impact studies in the UK, International Journal of Cultural Policy, 8(1), 91-106.

Camacho, C. F. (coord.) (2020). Relatório Final (preliminar) elaborado pelo Grupo de Projeto Museus no Futuro. Lisboa: ICOM Portugal. Disponível em https://icom-portugal.org/ wp-content/uploads/2020/07/Relat\%C3\%B3rio-Museus-no-Futuro-07-07-2020.pdf

Cardoso, G. (coord.) (2013). A Sociedade dos Ecrãs. Lisboa: Tinta da China.

Catin, A. (2020). Notre Condition - Essai sur le salaire au travail artistique. Saint-Denis: Riot Editions.

De Peuter, G. \& Cohen, N. S. (2015). Emerging labour politics in creative industries. In Oakley, K. e O'Connor, J. (eds.), The Routledge Companion to the Cultural Industries. London/ New York: Routledge, 305-318.

Eurostat (2019). Culture statistics - 2019 edition. Luxemburgo: Publications Office of the European Union. Disponível em https://ec.europa.eu/eurostat/documents/3217494/ 10177894/KS-01-19-712-EN-N.pdf/915f828b-daae-1cca-ba$54-a 87 e 90 d 6 b 68 b$

Ferrão, J. (2015). Cultura e território: como tornar mais eficiente uma política 'fraca'. In Costa, P. (coord.), Politicas Culturais para o Desenvolvimento: Conferência ARTEMREDE. Santarém: ARTEMREDE, 84-89.

Garcia, J. L.; Lopes, J. T.; Martinho, T. D.; Neves, J. S.; Gomes, R. T.; Borges, V. (2016). Mapping cultural policy in Portugal: From incentives to crisis, International Journal of Cultural Policy, DOI: 10.1080/10286632.2016.1248950, 1-17.

Gill, R. \& Pratt, A. (2008). In the social factory? Immaterial labour, precariousness and cultural work, Theory, Culture \& Society, 25 (7-8), 1-30.

Haiven, M. (2020). No Artist Left Alive-Speculations on the Post-Pandemic Dtruggles of Cultural Workers Within, Against and Beyond Capitalism. Disponível em: https://maxhaiven. com/no-artist-left-alive/

Halpern, M. (2020). Entrevista Graça Fonseca: "Nunca houve tanto dinheiro para a Cultura", Jornal de Letras, Artes e Ideias, Ano XL, № 1300, de 29 de Julho a 11 de Agosto, 6-8.

KEA \& PPMMI (2019). Research for CULT Committee - Culture and creative sectors in the European Union - key future developments, challenges and opportunities. Bruxelas: Parlamento Europeu/Departamento para as Políticas Estruturais e de Coesão. Disponível em https://www.europarl. europa.eu/RegData/etudes/STUD/2019/629203/IPOL_ STU(2019)629203_EN.pdf

Kern, P. (2020). The impact of the COVID-19 pandemic on the Cultural and Creative Sector. Report for the Council of Europe. Estrasburgo: Conselho da Europa. Disponível em https://keanet.eu/wp-content/uploads/Impact-of-COVID-19-pandemic-on-CCS_COE-KEA_26062020.pdf.pdf.

Maldonado, L.G. (2020). Porfavor, queel coronavirus nonostraiga (también) una cultura basura, El Español, 20 de Março. Disponível em https://www.elespanol.com/cultura/20200327/ favor-coronavirus-no-traiga-cultura-basura/477703832 0. 


\section{CADERNOS DAPANDEMIA S INSTITUTODE}

html? fbclid=IwAR1DXQs4rORr6ftOInUi_JdwTXTtxVKwmZrCsIYpYUUKhXDG4_1pvD3QIWQ

Martel, F. (2020). Cultural policies: Mapping a field in reinvention, State of the arts. Zurique: ZHDK/ZUA. Disponivel em https://www.zhdk.ch/file/live/e1/e123ea364fca50c558cb3465c7abaca4e1e78b22/2020_03_cultural-policies-mapping-a-field-in-reinvention-frederic-martel_article.pdf

Matarasso, F. (2020). Right now, being kind might be more important than being creative, Parliament of Dreams, 7 de Abril. Disponível em https://parliamentofdreams.com/2020/04/07/ right-now-being-kind-might-be-more-important-than-being-creative/

McGuigan, J. (2005). Neo-liberalism, culture and policy, International Journal of Cultural Policy, 11(3), 229-241.

McRobbie, A. (2002). Clubs to Companies: notes on the decline of political culture in speeded up creative worlds, Cultural Studies, 16(4), 516-532.

McRobbie, A. (2016). Be Creative: Making a living in the new culture industries. Cambridge/Malden: Polity.

Menger, P. M. (2005). Retrato do Artista enquanto trabalhador: Metamorfoses do Capitalismo. Lisboa: Roma Editora.

Merrill, R.; Bizarro, S.; Marcelo, G.; Pinto, J. (2019). Rendimento Básico Incondicional: Uma Defesa da Liberdade. Lisboa: Edições 70.

Miller, T. \& Yúdice, G. (2002). Cultural Policy. Londres: Sage.

Montalto, V.; Sacco, P. L.; Alberti, V.; Panella, F.; Saisana, M. (2020). European Cultural and Creative Cities in COVID-19 times: Jobs at risk and the policy response. JRC Science for Policy Report. EUR 30249 EN. Luxemburgo: Publications Office of the European Union. Disponível em https://ec.europa.eu/jrc/en/publication/eur-scientific-and-technical-research-reports/european-cultural-and-creative-cities-COVID-19-times

NEMO (2020). Survey on the impact of the COVID-19 situation on museums in Europe. Berlim: Network of European Museum Organisations. Disponível em https://www.ne-mo. org/fileadmin/Dateien/public/NEMO_documents/NEMO_ Corona_Survey_Results_6_4_20.pdf

Neves, J. S. (coord.) (2020a). Os Monumentos Nacionais de Portugal e a Abertura ao Público: impactos decorrentes da COVID19. Relatório. Lisboa: OPAC/CIES/ISCTE-IUL. Disponível em https://704a06ef-c151-4ad7-b67c-50cf9846cda5.filesusr. com/ugd/ee1deO_Oad36bc4c6ab4538874874a7613b68b5. pdf

Neves, J. S. (2020b). Cultura. In Mamede, R. P. \& Silva, P. A. (coord.), O Estado da Nação e as Políticas Públicas 2020: Valorizar as Políticas Públicas. Lisboa: IPPS/ISCTE-IUL, 25-32. Disponível em https://ipps.iscte-iul.pt/index.php/estudos-e-publicacoes/estudos-e-publicacoes-3/784-2020-valorizar-politicas-publicas

O'Connor, J. (2020). Art and Culture After COVID-19, Wake in Fright, 9 de Abril. Disponível em: https://wakeinalarm. blog/2020/04/09/art-and-culture-after-COVID-19/.

Polivtseva, E. (2020). Live Arts in the Virtualisation World. Bruxelas: IETM. Disponível em https://www.ietm.org/en/system/files/publications/live_arts_in_the_virtualising_world. pdf
Ross, A. (2000). The Mental Labor Problem, Social Text, 63, 2(18), 1-31.

Ross, A. (2008). The new geography of work: Power to the precarious?, Theory,

Culture \& Society, 25(7-8), 31-49.

Ross, A. (2009). Nice Work If You Can Get It: Life and Labor in Precarious Times. Nova lorque: NYU Press.

Quintela, P. (2017). A obscuridade do trabalho na "agenda" criativa em Portugal, Atas do IX Congresso Português de Sociologia, "Portugal: Território de Territórios". Lisboa: APS - Associação Portuguesa de Sociologia. Disponível em https://associacaoportuguesasociologia.pt/ix_congresso/ docs/final/COM0288.pdf

Quintela, P. \& Ferreira, C. (2018). Indústrias culturais e criativas em Portugal: um balanço crítico de uma nova 'agenda' para as políticas públicas no início deste milénio, Todas As Artes, 1(1), 89-111. Disponível em http://ojs.letras.up.pt/index.php/ taa/article/view/5041

Rodrigues, V. (no prelo). A colaboração nas artes do ponto de vista da produção e gestão cultural: entre a invisibilidade e o desejo de mudança, Revista de História da Arte - Série W.

Rodrigues, V. \& Quintela, P. (2020). Pandemia e cultura: a urgência de um pensamento lento, Público, 10 de Abril. Disponível em https://www.publico.pt/2020/04/10/culturaipsilon/opiniao/pandemia-cultura-urgencia-pensamento-lento-1911791

Salema, I. (2020). A Cultura teve "um diálogo bom" com o autor do plano estratégico, Público, 22 de Julho, 11.

Simão, F. S. (2020). Authors' Rights and Rights' Authors: on the relationship between copyright and artistic work. Tese de Doutoramento. Porto: FBAUP.

Silva, A. C. (2020). Plano de Recuperação Económica de Portugal 2020-2030. Junho. Lisboa: Governo de Portugal. Disponível em https://www.portugal.gov.pt/pt/gc22/comunicacao/documento?i=visao-estrategica-para-o-plano-de-recuperacao-economica-de-portugal-2020-2030

UCLG Culture Committee (2020). Culture, Cities and the COVID19 Pandemic; Part One: Documenting the Initial Measures and Drafting Challenges Ahead, UCLG Committee on CUlture Reports, 8, Barcelona: UCL. Disponível em https://www. interarts.net/wp-content/uploads/2020/08/report_8_culture_cities_covid19_-_eng_O-compressed.pdf

UNESCO (2020). Museums around the world in the face of COVID-19. Paris: UNESCO. Disponível em https://unesdoc. unesco.org/ark:/48223/pfO000373530

Urfalino, P. (1996). L'invention de la politique culturelle. Paris: Documentation Française. 


\section{CADERNOS DAPANDEMIA

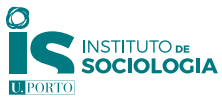

\section{TRABALHO NAS ARTES: BREVE GUIÃO PARA RECONHECER DIREITOS}

Amarílis Felizes*

Confrontamo-nos hoje com as consequências funestas da precariedade do trabalho no sector das artes. No ano em que a pandemia está a trazer à tona, como nunca, a violência da insegurança laboral nesta área; e em que o governo português, face a uma renovada combatividade, se vê forçado a abrir uma negociação, sem precedentes, sobre a proteção social neste sector, este volume dos Cadernos da Pandemia revela-se precioso.

Com a paralisação a que a pandemia obrigou, milhares de trabalhadoras e trabalhadores das artes viram-se a braços com grandes dificuldades para manter satisfeitas as suas necessidades mais básicas. Uma grande parte não tem acesso a subsídio de desemprego, dada a generalização da inexistência de vínculos (como se todo o trabalho fosse autónomo), e teria ficado sem qualquer proteção social, não tivesse sido distribuído um apoio específico, ainda que parco e insuficientemente abrangente, destinado a trabalhadores independentes e criado de propósito para responder ao flagelo.

Esta é a consequência de uma história de precariedade e fraude laboral. A generalização dos recibos verdes para todas as tarefas, a prestação do trabalho através de empresas em nome individual ou o falso trabalho externalizado que

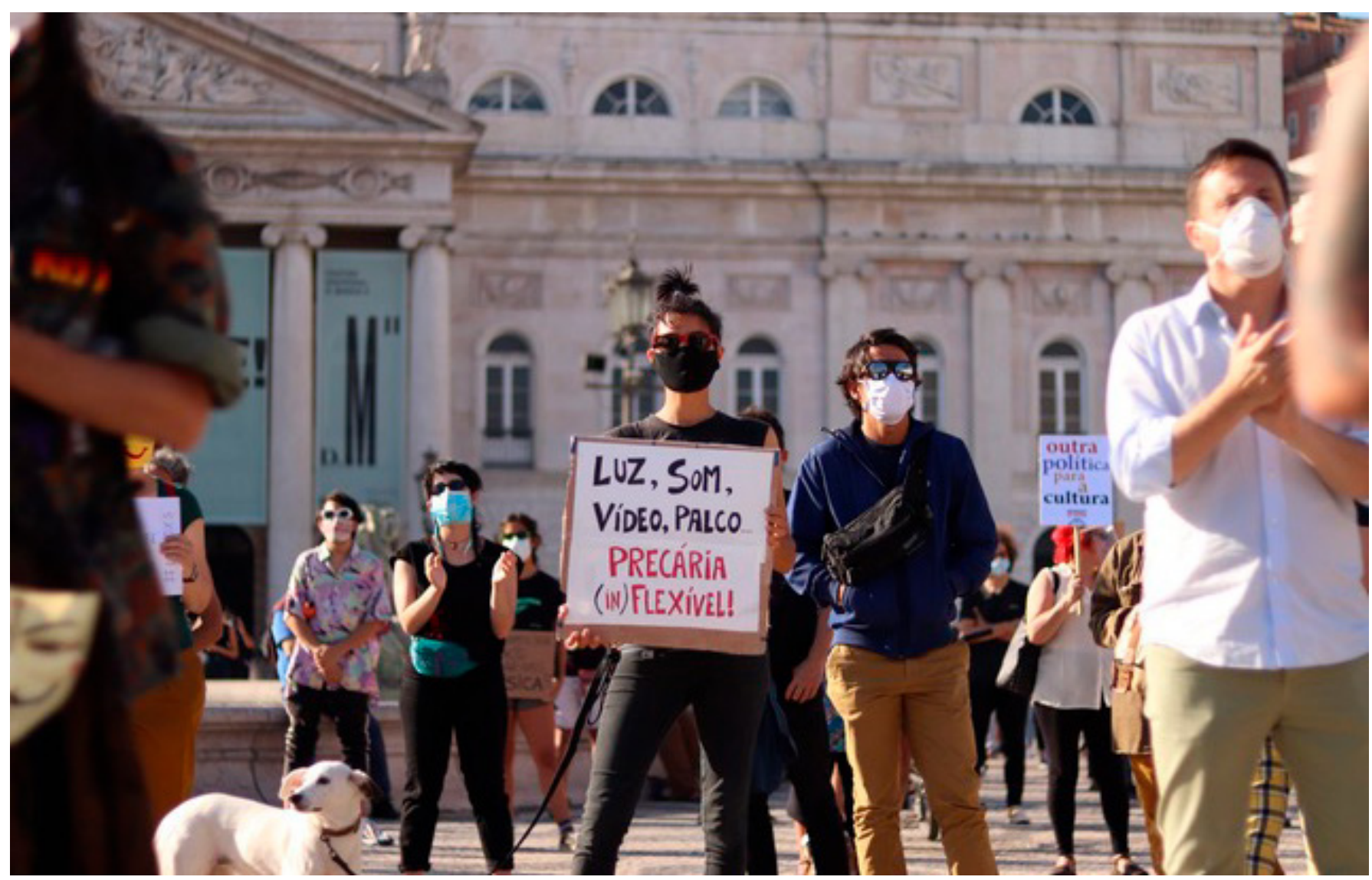

Figura 1 - Manifestação 'Parados, nunca calados'. Manifestação convocada pelo Cena-STE e realizada no dia 4 de junho, no Porto e em Lisboa. - (CENA-STE ( 2020 ) 


\section{CADERNOS DAPANDEMIA 0 INSTITUTO DE}

constituem hoje a cultura laboral do sector - a par da falta de um regime de proteção social adequado à intermitência de alguns destes trabalhos - determinam a precariedade da vida de quem, acima de tudo, recebe sempre muito pouco pelas coisas extraordinárias que faz.

Ao longo de décadas, falharam as políticas laborais e culturais, e falharam as instituições públicas, ao manterem no seu seio as piores práticas. É o caso de instituições que se supunham exemplares, como a Casa da Música ou a Fundação de Serralves. Quando a pandemia determinou o cancelamento - por envolverem grandes equipas ou serem destinados à fruição pública e coletiva - dos projetos em que milhares de pessoas iam trabalhar, a ausência de segurança laboral tornou-se fatal.

\section{Uma combatividade renovada}

Em resposta à excecionalidade da situação, vieram a público cartas abertas, artigos de opinião e petições às dezenas. Formaram-se grupos de debate e de ação solidária e reivindicativa. Aumentaram as adesões às associações representativas do sector e aos sindicatos, e tiveram lugar manifestações de rua. A urgência do momento e a reivindicação de medidas de emergência dominaram os debates. Mas a reflexão de longo termo sobre a necessidade de um novo modelo de proteção social foi também surgindo, sendo o modelo francês múltiplas vezes citado. Contudo, o debate parece começar do zero, como se perante cada nova crise começasse tudo de novo e não tivéssemos já uma história nestas discussões, como se pudéssemos prescindir da memória e do trabalho entretanto acumulado, nomeadamente daquele que levou a cabo, há mais de uma década, a Plataforma dos Intermitentes do Espectáculo e do Audiovisual, iniciativa que juntou cerca de uma dezena de organizações do sector ${ }^{50}$ para "defender ativamente a criação de uma lei que reconhe[cesse] o direito dos intermitentes à contratação e o acesso a um regime de segurança social adaptado à intermitência”.

Mas se este debate não é novo, estão muito longe de ser satisfatórias ou suficientemente desenvolvidas as respostas aos vários problemas que se vivem no trabalho no sector das artes - dos quais a intermitência, ou a descontinuidade de rendimentos e de trabalho, é apenas um.

Face a uma forte contestação à falta de respostas políticas à crise provocada pela pandemia, que fez saltar aos olhos um panorama de generalizada falta de proteção social neste sector, o Governo português avançou, em pleno 'estado de emergência', com a ideia de criar um "estatuto da intermitência"51. Passados mais de quatro meses ainda não se conhece nenhuma proposta de medida ou sequer intenção do Governo quanto ao estatuto. Por seu turno, em julho de 2020, o Cena-STE (Sindicato dos Trabalhadores de Espetáculos, do Audiovisual e dos Músicos), a APR (Associação Portuguesa de Realizadores) e a Plateia (Associação de Profissionais das Artes Cénicas), divulgaram um documento ${ }^{52}$, em jeito de "pontapé de

50 Em 2006 reuniam-se nesta plataforma a AIP - Associação de Imagem Portuguesa, Associação Novo Circo, ARA Associação de Assistentes de Realização e Anotação, ATSP - Associação dos Técnicos de Som Profissional, CPAV Centro Profissional do Sector Audiovisual, Encontros do Ator, GDA - Gestão dos Direitos dos Artistas, Granular - Associação de Música Contemporânea, Movimento dos Intermitentes do Espetáculo e do Audiovisual, PLATEIA -Associação de Profissionais das Artes Cénicas, REDE - Associação de Estruturas para a Dança Contemporânea, RAMPA, Sindicato dos Músicos, SINTTAV - Sindicato Nacional dos Trabalhadores das Telecomunicações e Audiovisual e STE - Sindicato das Artes do Espetáculo. Em 2011 algumas das pessoas mais envolvidas no movimento dos intermitentes criaram o sindicato CENA.

51 https:/Www.publico.pt/2020/05/06/culturaipsilon/noticia/ covid19-governo-cria-grupo-trabalho-analisar-situacao-laboral-artes-1915335.

52 https://www.publico.pt/2020/07/29/culturaipsilon/noticia/ cinco-medidasbase-atacar-precariedade-cultura-caderno-reivindicativo-chega-semana-ministra-1926261? fbclid=1WAR2AEGhfU6wciUo-nPY3mRV660G2S3ITMZKCOb8YyqNTQCO4pvhIKG6PVWI. 


\section{CADERNOS DAPANDEMIA \\ SOCIOLOCI}

saída" para esta discussão. Aqui, são defendidos cinco pontos de implementação essencial para se combaterem as fragilidades laborais do sector, que deslaçam algumas armadilhas do senso comum sobre o trabalho nas artes - que é o que me proponho aprofundar neste artigo.

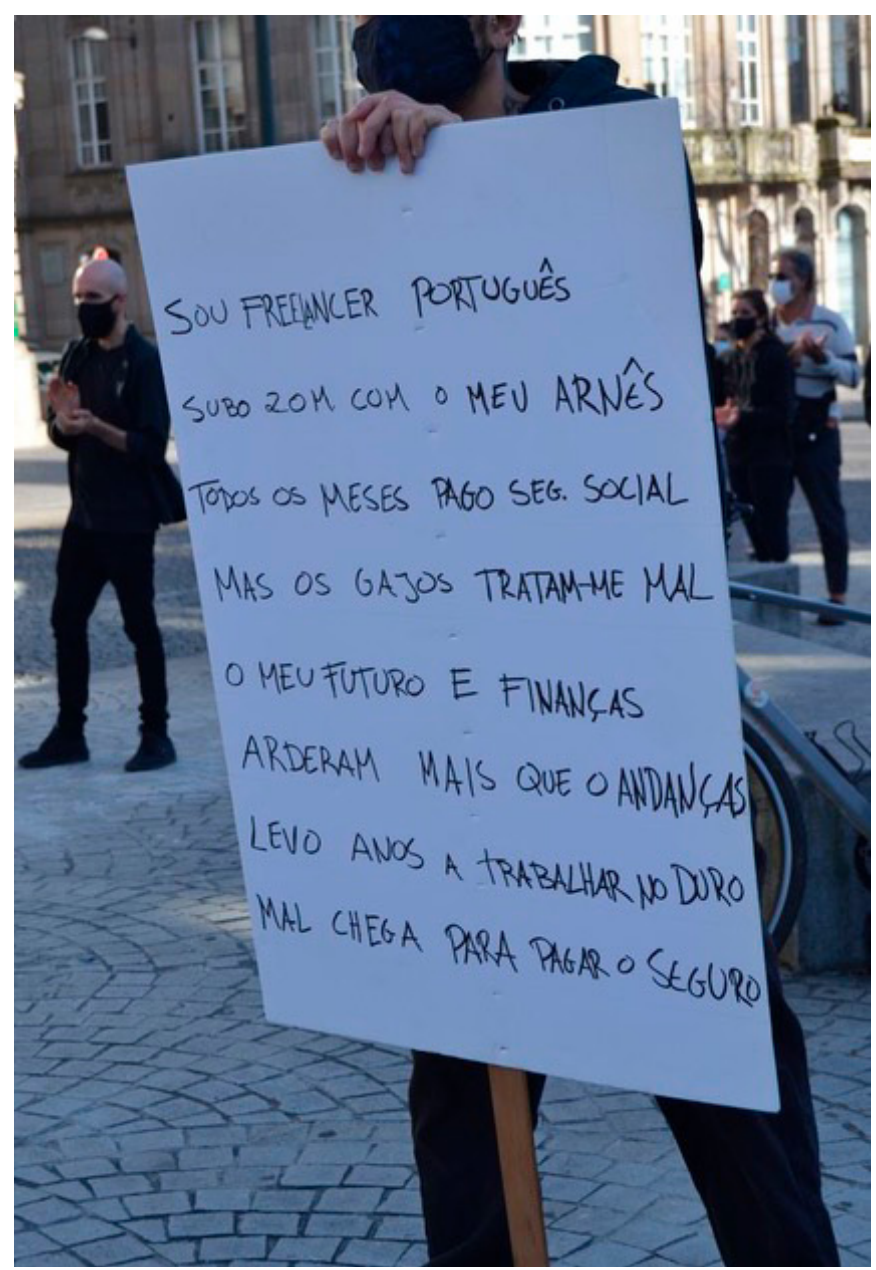

Figura 2 - Manifestação 'Parados, nunca calados' na Avenida dos Aliados, Porto. Manifestação convocada pelo Cena-STE e realizada no dia 4 de junho, no Porto e em Lisboa. (CENA-STE @ 2020)

\section{Os mitos sobre o trabalho nas artes}

À discussão sobre o que é preciso mudar nas leis, precede a necessidade de conhecermos os direitos que já temos. Mas a distância entre as práticas e a lei é tão grande, que distorce o entendimento dos trabalhadores sobre esses seus direitos. Nas artes, a força dos conceitos de autonomia e independência ajudam a criar alguns mitos sobre a forma como se devem estabelecer, ou não, relações de trabalho.

\section{Somos todos trabalhadores independentes?}

Falamos aqui de dezenas de profissões em áreas tão diversas como o cinema, a música, o teatro ou as artes plásticas, em atividades que vão da criação artística à manutenção dos espaços e meios de difusão, divulgação e mediação. Trata-se de um tecido constituído por instituições tão diversas como as entidades e equipamentos públicos (maiores ou menores), as grandes empresas, os pequenos grupos independentes e os freelancers, os grandes eventos e as distribuidoras. Mas é comum a esta heterogeneidade uma cultura laboral assente no recibo verde e noutras formas de trabalho autónomo, ao arrepio da legislação laboral. A pequena companhia de teatro paga ao ator e à operadora de som ou luz através de recibo verde, o grande festival de música paga à produtora através de recibo verde, o teatro público paga ao assistente de sala através de uma empresa externa, a televisão pública faz o mesmo com uma série de operadores de câmara e outros técnicos, etc.

Em todos estes casos e numa parte substancial dos recibos verdes, há, na verdade, uma relação laboral que deve ser estabelecida através do contrato de trabalho ${ }^{53}$. Em muitos casos, onde hoje há o recibo verde, a lei laboral obriga à existência de um contrato que tenha predefinido, por exemplo, o tempo de trabalho, a remuneração, os encargos sociais do empregador e os encargos sociais do empregado.

Existindo uma lei que permite o estabelecimento de contratos de trabalho adequados às especificidades das atividades da área artística - a

53 Ver artigo 12. do Código do Trabalho - Presunção de Contrato de Trabalho (http://WWW.pgdlisboa.pt/leis/lei_mostra_articulado.php?artigo_id=1047 A0012\&nid=1047\&tabela=leis\&pagina=1\&ficha=1\&so_ miolo=\&nversao=\#artigo). 


\section{CADERNOS DAPANDEMIA SOCIOLOCI}

Lei 4/2008, que aprova o regime dos contratos de trabalho dos profissionais de espetáculos ${ }^{54}-$ nada pode legitimar esta prática, que tem como fim evitar um contrato com mais encargos sociais para a entidade empregadora, passando esses custos para o trabalhador.

\section{O que é a intermitência e como garantir direitos nestes casos?}

Existem profissões onde é corrente a passagem de um trabalho para outro e o trabalho por períodos curtos (mudando-se, a cada vez, de empregador), alternado com períodos de paragem total. Mas o regime geral da segurança social foi pensado para responder a situações em que os rendimentos são constantes, e é ineficaz na proteção de quem tem rendimentos que resultam de um trabalho projeto a projeto, descontínuo e móvel.

Para que quem assim trabalha tenha acesso aos mesmo direitos que outro trabalhador, é necessário rever os seus prazos de garantia, ou valores de garantia, para se aceder ao subsídio de desemprego. Nestes casos, os prazos de garantia podem, por exemplo, ser determinados através da definição de um dado número mínimo de horas de trabalho durante um certo período (507 horas por ano é o caso francês) para aceder, durante um certo tempo (12 meses, no exemplo francês), ao subsídio de desemprego. Os valores de garantia podem servir para os trabalhadores cujo trabalho não é fácil de contabilizar em horas: trata-se de um valor mínimo de rendimentos obtidos durante um certo período, que é o necessário para aceder ao subsídio de desemprego, a fim de resolver a questão da descontinuidade dos rendimentos.

Alguns países europeus têm já definidas e estabelecidas regras para enquadrar a intermitência, enquanto modo de trabalho com os respetivos direitos. Este enquadramento permitiu a estes trabalhadores uma proteção social equiparada à dos restantes trabalhadores, com subsídios de férias,

54 https://dre.pt/web/guest/pesquisa/-/search/248247/ details/normal?p_p_auth =jgsOD3Fb. de parentalidade, de doença alargada, assim como um acesso ao subsídio de desemprego, procurando certo equilíbrio na distribuição da responsabilidade dos encargos sociais entre os empregadores e os trabalhadores. Nestes países, é visível o efeito positivo, para a vida cultural e para a dinâmica artística, desta adaptação às especificidades laborais de alguns trabalhadores da cultura, no plano de uma política cultural estruturada.

\section{Somos todos intermitentes?}

Quando se desempenham funções permanentes e de forma dependente para a mesma entidade, quando se ocupa um posto de trabalho que é sempre necessário em certa empresa, grupo ou instituição, deve ser assegurada a celebração de contratos sem termo, de modo a terminar com a banalização do contrato de curta duração, do falso recibo verde e do falso trabalho externalizado (quer através de empresas em nome individual, quer de falsos intermediários).

O Estado deveria ser o primeiro a dar o exemplo, integrando os trabalhadores precários das entidades públicas (centrais e locais, da área da cultura), e garantindo que, na atribuição de financiamento público para a entidades ou projetos artísticos, as estruturas independentes prevejam sempre, nos seus orçamentos, os encargos sociais dos trabaIhadores que integram as respetivas equipas. $O$ Estado deveria, igualmente, realizar uma efetiva e sistemática fiscalização das relações laborais neste sector, prevendo formação especializada para a Autoridade para as Condições do Trabalho (ACT).

\section{Nas artes e em todo o lado}

Em Portugal, cerca de metade das pessoas desempregadas não tem acesso ao subsídio de desemprego. As lógicas do neoliberalismo, tanto na própria produção como nas políticas culturais, estão a empurrar-nos constantemente para a condição de trabalhadores independentes ou mesmo de empresários em nome individual. Esta 


\section{CADERNOS}

transformação na regulação das relações laborais, com um quarto da força de trabalho - um milhão de pessoas - a prestar o seu trabalho de forma "autónoma", obriga a repensar a proteção social que existe.

Conhecemos de perto e sentimos no corpo o que é sermos empresários de nós próprios: é, em contexto de crise, a dureza da insegurança, causada pela dissimulação e negação de contratos. $O$ debate que hoje se faz sobre o mercado de trabalho cultural, e nele a questão da intermitência, tem no centro o desenho da proteção social para as modalidades de trabalho próprias das atividades ligadas às artes, e a garantia de direitos sociais básicos para quem trabalha projeto a projeto. Mas obriga também a repensar uma política cultural que até agora se tem mostrado ausente, errática e voluntarista, num contexto em que o orçamento nunca chega para implementar qualquer estratégia.

Estamos confrontados com um triplo desafio, e nenhum dos objetivos deve servir para anular o outro: precisamos de garantir proteção social a quem tem profissões autónomas, empregos descontínuos e vários empregadores; precisamos de reconhecer relações laborais onde hoje há falsos recibos verdes ou falso outsourcing; e precisamos de reconhecer que há postos permanentes a ocupar também no sector cultural, com os respetivos contratos efetivos.

\section{Porto, outubro de 2020.}

*A autora segue as normas do Acordo Ortográfico da Língua Portuguesa de 1990. 


\section{CADERNOS DAPANDEMIA SOCIOLOCI}

\section{PARTE II}

\section{O TRABALHO NAS ARTES PERFORMATIVAS NA ERA COVID-19: DA URGÊNCIA AO POTENCIAL DA MUDANÇA NAS ORGANIZAÇÕES E NAS TRAJETÓRIAS DE CARREIRA ARTÍSTICAS}

\author{
Vera Borges*
}

\section{Resumo}

O trabalho artístico tem sido alvo de muitas e profundas transformações que se agravam em períodos de crise, como este que vivemos associado à COVID-19. A rápida e vasta propagação do vírus e os seus efeitos radicais levaram ao cancelamento dos espetáculos ao vivo e ao encerramento dos espaços culturais. Nestes espaços incluem-se teatros, salas de ensaios e estúdios de dança, teatro, música, filmagens, salas de concertos, espaços lúdicos e recreativos. Em Portugal, como nos outros países europeus e um pouco por todo o mundo, o trabalho dos profissionais dos setores culturais e artísticos foi dos mais afetados, em especial, no domínio das artes performativas. Não é de estranhar, as condições de trabalho destes profissionais são as mais vulneráveis e precárias, as suas trajetórias de carreira as mais incertas e as desigualdades em relação ao volume de trabaIho e aos rendimentos auferidos são assinaláveis, face à situação dos sistemas de produção das indústrias culturais e de outros setores de atividade. A investigação feita nos últimos 20 anos e os testemunhos dos artistas e profissionais das artes retratavam a situação e denunciavam o seu agravamento, desde 2008. Neste texto, analisa-se como é que as políticas públicas e as organizações gerem e enfrentam a crise, concluindo-se que, depois da urgência, são estas organizações e estas pessoas o nosso maior potencial para a mudança nas artes.

Palavras-chave: trabalho artístico, organizações, profissionais das artes performativas.

\section{Os principais pontos de partida}

Nas duas últimas décadas, a situação das artes performativas, dos seus profissionais e organizações agravou-se. Desde a crise financeira de 2008 que o tecido artístico português se encontra mais debilitado e vulnerável ao crónico subfinanciamento público (Garcia et al., 2016). Num pequeno estudo recente, que realizei com Luísa Veloso, no CIES-Iscte, pouco antes da era COVID-19, em colaboração com um conjunto de profissionais das artes performativas, concluímos que uma pequeníssima parte destes profissionais tem emprego permanente nas organizações mais estáveis, apoiadas pelo Estado e pelos municípios; outra parte importante apresenta-se como independente e lidera ou está ligada a projetos "em carteira" que se renovam em função de apoios nacionais, locais e europeus; outra parte dos profissionais independentes gravitam entre organizações permanentes e organizações que operam por projeto, com convites recorrentes; por fim, os independentíssimos que trabalham nas "margens" da criação artística e que, neste momento, correm o risco de (des)integração nos campos artísticos dominantes (Borges e Veloso, 2020).

Esta pluralidade de trajetórias profissionais emerge e perpassa nos quatro principais modelos de organizações - também eles com grande diversidade interna - que caracterizam o trabalho nas artes performativas no nosso país:

(i) as estruturas permanentes dedicam-se exclusivamente ao trabalho artístico, com o apoio regular do Estado e dos municípios, gerem pequenas equipas permanentes; sublinha-se o forte trabalho das suas equipas de produção e comunicação fixas, com um número reduzido de artistas que trabalham a tempo inteiro e um número importante de artistas convidados regularmente;

(ii) as estruturas por projeto têm o apoio do Estado e dos municípios para a realização dos projetos, as suas equipas são muito pequenas, um ou dois profissionais permanentes asseguram a coerência interna do projeto artístico, um ou dois membros fixos na equipa de produção e comunicação, com convites pontuais a outros artistas e estruturas; 


\section{CADERNOS}

DAPANDEMIA

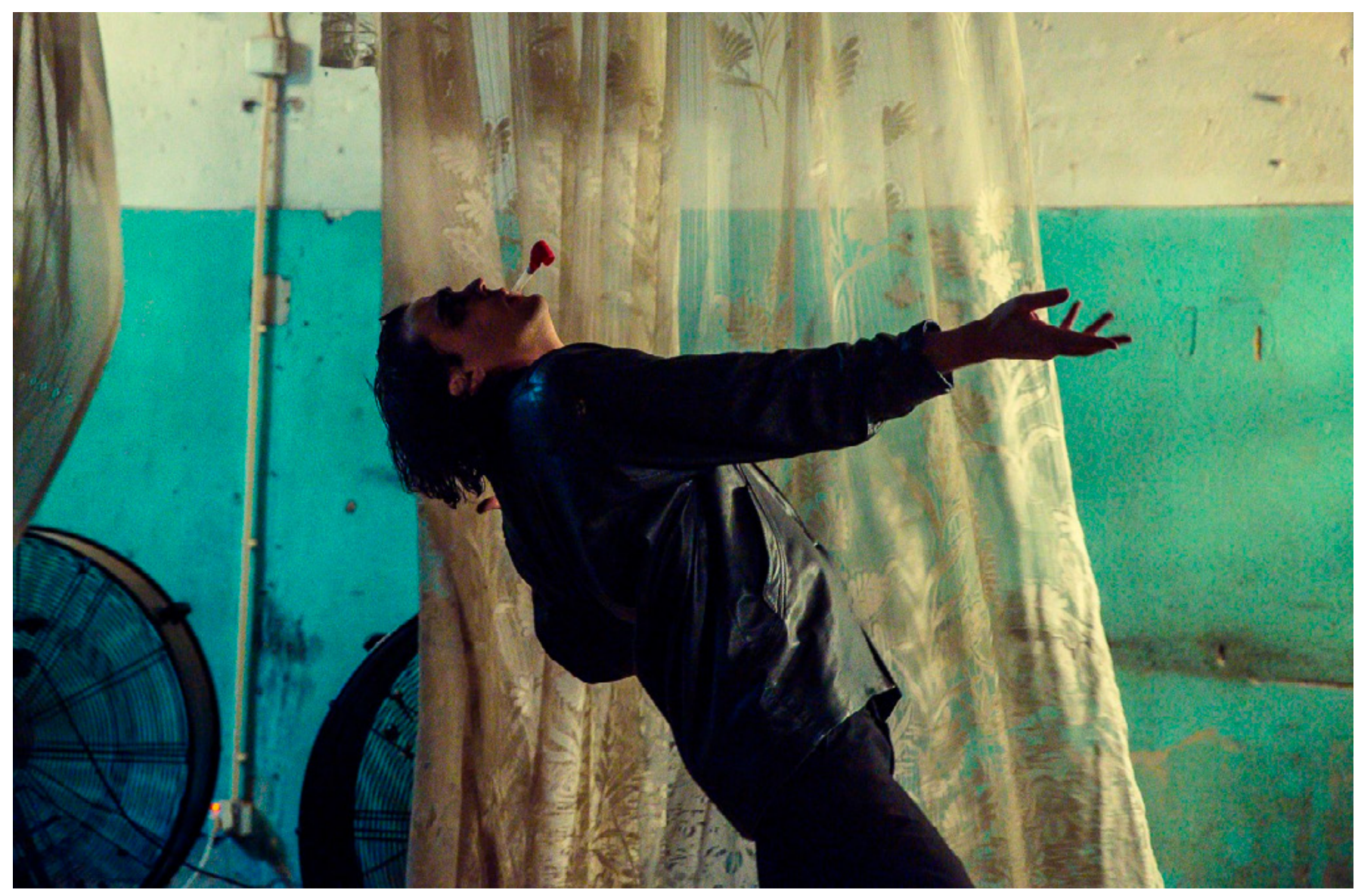

Figura 1 - Tiago Vieira, em “Julieta bebe uma cerveja no inferno”, Latoaria, Graça, em Lisboa. · (c)Alípio Padilha).

Cedência para cartaz de Talk - Conversas sobre Arte e Cultura. · Organização: Vera Borges, CIES-ISCTE.

O trabalho artístico (emergente) em Lisboa: dilemas e oportunidades, com Tiago Vieira, Tânia Guerreiro, Luísa Veloso e Vera Borges.

(iii) as estruturas independentes são constituídas por artistas que não têm, diretamente, um apoio regular do Estado. Realizam atividades conexas e têm o apoio de outras plataformas (de produção, logística); partilham espaço com outros independentes, mas podem não partilhar o trabalho artístico. Poderá tratar-se de casos de resiliência numa franja de profissionais, ainda mais precários, e o culminar do "individualismo de um mercado [cada vez mais] competitivo" (O'Connor, 2020);

(iv) por fim, as estruturas hibridas que emergem como espaços de convívio, plataformas de experimentação e integração profissional de alguns artistas, com apresentações de teatro, dança contemporânea e música. As aulas e as sessões de teatro, dança (dança de rua, africana, cigana e flamenca, étnica) e música (soul, reggae, jazz, pop/rock, rap, tecno, punk, asiática, africana brasileira), os mercados, serviços de bar e refeições sustentam as estruturas.

Os dois primeiros perfis são apoiados pelo Estado, através da DGArtes e marcam uma parte importante da diversidade do tecido de criação 


\section{CADERNOS DAPANDEMIA 0 SONSTIUTO DE}

artística, no país ${ }^{55}$. Recentemente, estas estruturas foram estudadas pela DGArtes e os resultados podem ser consultados no estudo Posicionamentos das Entidades Artísticas no âmbito da Revisão do Modelo de Apoio às Artes (Neves, Azevedo, Gomes e Lima, 2017). Considero ainda importante contemplar dois outros perfis, onde residem a forte incerteza e precariedade, mas, apesar de tudo isso, representam pontos de viragem, uma vez que as estruturas assumem um papel importante nas "margens" da criação artística independente; e, no último caso, concentram as micro-estruturas de conexão com os mundos profissionais das artes e chegam a públicos com gostos e práticas de consumo cultural muito heterogéneos, ora elitistas ora de carácter mais expressivo e quotidiano (Rego e Borges, 2020). Estas estruturas estão "fora do radar" das políticas públicas para a cultura, em Portugal, mas representam alternativas aos contextos de crise permanente e poderão ter um papel cultural e social mais importante no período pós-COVID-19, pois promovem uma estreita ligação dos indivíduos aos territórios ( $v$. experiência internacional, Borges, 2020).

Em geral, as organizações artísticas estão envolvidas em sistemas de trabalho muito precários que não conseguem consolidar a situação laboral dos artistas e outros profissionais que com eles colaboram, por convite; por regra, são profissionais mais jovens e a trabalhar ao projeto, entre o teatro e a televisão, e com forte presença nos media sociais. A hiperflexibilidade e a insegurança do trabalho nas artes performativas é conhecida de todos, sabemos que os profissionais estão inseridos em redes de trabalho descontínuas, com salários baixos, sem segurança e, por vezes, sem perspetivas de futuro (Borges e Pereira, 2012). O que

55 Consultar: https:/www.dgartes.gov.pt/sites/default/files/ files/boletimanual05.pdf (Boletim Anual das Artes, 2014, com análise de V. Borges); https:/Www.dgartes.gov.pt/ sites/default/files/files/boletimtrimestral_04.pdf https:/ www.dgartes.gov.pt/sites/default/files/files/boletimtrimestral03.pdf; https://www.dgartes.gov.pt/sites/default/files/ files/boletimtrimestral02.pdf

Mais recentemente: DGArtes em Números, Relatório Estatístico. Disponivel em: https:/Www.dgartes.gov.pt/sites/default/ files/dgartesemnumeros_relatorioestatistic02017.pdf. faz pensar até que ponto a urgência de sobrevivência económica dos profissionais do espetáculo se tem vindo a constituir como uma imposição ao seu trabalho de criação (Borges e Lima; 2014; Borges, 2017, 2018, 2019). Em particular, o trabaIho realizado nas "margens" do sistema, embora, a precariedade e a intermitência sejam, há muito, características globais das trajetórias de carreira artísticas.

Mas como podem os artistas e os profissionais das artes, em geral, desenvolver bem o seu trabalho se assistimos ao emagrecimento progressivo (e ao colapso) das organizações artísticas? A crescente fragilização das condições de trabalho dos artistas empreendedores que têm de encontrar os meios para trabalhar - como se os profissionais das artes tivessem um kit de estratégias e ferramentas de sobrevivência que acionam de forma voluntária - mostra-nos, afinal, como estão dependentes das políticas públicas e dos seus recursos pessoais, familiares e sociais para obterem as condições materiais necessárias para realizarem o seu trabalho. Os tempos são propícios ao pessimismo, mas a análise é construtiva e leva-me a destacar as forças, as novas dinâmicas e equilíbrios, e, por sua vez, os desequilíbrios e fragilidades permanentes que teremos de resolver. Esta parte da minha contribuição organiza-se em torno de três pontos, que desenvolvo no texto, e com os quais vou dialogando (em itálico), por esta ordem: (i) a importância de fortalecer os diferentes tipos de organizações artísticas que existem no país e, com isso, apoiar artistas e profissionais das artes com diferentes trajetórias;

(ii) a forma como as políticas públicas para a cultura e as organizações artísticas têm gerido e enfrentado esta crise mostra uma forte motivação de todos para se passar da ação urgente às medidas robustas e de longo prazo;

(iii) como é que essas medidas podem representar a mudança nos padrões do trabalho artístico e nos padrões de consumo e participação cultural, tendo em conta o papel das organizações - apoiadas ou não pelo Estado -, e o seu impacto na vida quotidiana e no bem-estar das populações, na era pós-C19. 


\section{CADERNOS DAPANDEMIA $\underbrace{\text { SNSTITUTODE }}_{\text {OUPORTO }}$ SOCIOLOGIA}

\section{Qual é o valor do trabalho artístico em tempos de crise?}

O valor do trabalho artístico é, continuamente, posto à prova pelas condições de trabalho que, a não ser em contextos institucionalmente fortes, se tornam ainda mais precárias em tempos de crise. No momento que vivemos, saliento a atuação exemplar - infelizmente, não foi assim com todas elas - de algumas das nossas organizações permanentes, como o Teatro Nacional D. Maria II, em Lisboa. Pela ação do seu diretor, o ator e encenador Tiago Rodrigues, o teatro tornou possível que os espetáculos agendados, mas cancelados, fossem pagos aos artistas, demonstrando grande agilidade na procura de medidas de ação rápida, justas e eficazes, e, no fundo, sendo produtor de micro-políticas públicas urgentes. Foi o sinal dado pela instituição para que não se deixassem os "artistas sem rede" (Borges, 2002) e para que se procurassem tornar menos devastadores os impactos da crise que deixou, mais visível, a falta de proteção laboral dos profissionais das artes e a inexistência de mecanismos de compensação.

Diferentes tipos de organizações e profissionais das artes performativas responderam - à medida das suas possibilidades - a mais esta crise, dando-nos a possibilidade de assistir aos espetáculos pela internet, através de transmissão ao vivo (livestreaming) e/ou descarga digital. Assim, organizações e profissionais da arte disponibilizaram gratuitamente espetáculos que estavam gravados em formato vídeo e realizaram outros, nas suas casas ou nos teatros vazios. Destaco apenas algumas das muitas e diferentes experiências de livestreaming, no Facebook, Twitter, canal Youtube, nomeadamente, experiências de projetos de teatro e dança que culminaram com a sua apresentação e divulgação online, com os artistas sozinhos ou a trabalhar em conjunto com outros profissionais, e, em alguns casos, com os participantes locais. São exemplos ilustrativos, a sessão final do trabalho ZUMIN, dirigido por Aldara Bizarro, realizado com os participantes, a partir do seu trabalho numa coletividade, a SMUP (Parede); a experiência na rádio 23 Milhas (ílhavo), com a leitura da peça de Pedro Penim, As obras no escuro; e a sua experiência internacional, uma das quais com o espetáculo DOING IT, apresentado no TBA (Teatro do Bairro Alto), na versão pré-Covid, que terá ainda a versão online ao vivo no Festival Internacional de Artes de Belfast; a experiência (de teatro e cinema), "O Teatro e a Peste", de Antonin Artaud, com conceção de John Romão, com cinco transmissões em streaming, a partir de diferentes teatros.

As experiências de livestreaming dos teatros nacionais e municipais e das instituições culturais, em geral, permitiram-nos também visionar horas de muitos e bons espetáculos e, nalguns casos, assistiram-se às interações mantidas pelos públicos que, conectados via Facebook, sentiam-se à vontade para comentar e dirigir palavras de incentivo ao trabalho do ator e da instituição, como aconteceu com o Teatro Nacional D. Maria II, com a leitura integral d'Os Lusíadas, no Dia de Portugal. A Sala e a Salinha Online (esta última destinada ao público infanto-juvenil) do D. Maria II, em Lisboa, e ainda o canal vimeo do Teatro Nacional S. João, no Porto, são também bons exemplos de teatro em casa. Outros teatros criaram momentos alternativos para responder a mais este desafio, como o TBA, cuja experiência com as sessões podcast "Dito e Feito", quando este teatro tinha apenas um espaço em obras e um telefone, foi decisiva para a sua alternativa online: The Script: Make yourself at Home, de Liesbeth Gritter, e Maratona de Procrastinação, de Sílvia Pinto Coelho. Destaque para a disponibilização de gravações de espetáculos encenados nos teatros, anteriormente gravados, por exemplo, pelo Teatro São Luiz, pelo Teatro Aberto (com a iniciativa "Teatro em Casa"), pelo Teatro Experimental de Cascais, entre outras estruturas apoiadas pela DGArtes. Contaram-se, ainda, as gravações de espetáculos como fez o Teatro da Garagem, com a série "Mundo Novo", em 16 episódios; o Teatro do Noroeste, do Centro Dramático de Viana ("Teatro do Noroeste em sua casa"), os podcasts do Projeto CRETA, Laboratório de criação teatral, do Teatro da Cidade, apoiado pelo Programa Viseu Cultura - Animar, promovido pela Câmara Municipal de Viseu. Estas e muitas, muitas outras experiências representam a criação de bens culturais diversos, feitos a partir de casa, ou, 


\section{CADERNOS DAPANDEMIA 2 INSTITUTO DE}

numa fase posterior, feitos nos teatros fechados, mas vistos em casa, que se tornou o local de trabalho, de lazer e consumo cultural, pelos serviços de televisão - destaque para a programação RTP Palco - streaming, rádio e online. Ultimamente, os teatros abriram as suas portas: o Teatro Nacional S. João, no Porto, e o Teatro Nacional D. Maria II, em Lisboa, deram-nos as boas vindas, assim como o Descon'FIMFA Lx20 - Tarumba e FIMFA, o Festival Todos - Caminhada de Culturas, promovido pela Academia de Produtores Culturais e pela Câmara Municipal de Lisboa, funcionou em São Vicente e Santa Engrácia, mas também no digital, \#TODOSemlinha; as Caminhadas com Arte, Conversas na natureza/Talks in nature, em Aljezur e Monchique, programadas pelo Lavrar O Mar, com o apoio nacional, Programa 365 Algarve, e da União Europeia; o Festival de Artes Performativas, MUSCARIUM\#6, em Sintra, programado pelo Teatro Mosca, no Auditório Municipal António Silva, no Cacém. Entre muitos outros exemplos.

A abundância de conteúdos artísticos, workshops, leituras, podcasts, entrevistas online, que foram pensados pelos artistas ou por estes e pelos diretores, programadores e produtores, resultou da urgência de mudar para a produção online, o que colocou os profissionais das artes, uma vez mais, à prova. Este tipo de trabalho pode comportar muitos riscos e fragilidades se for produzido com base na "contínua auto-exploração dos artistas" (Tsioulakis, Fitzgibbon, 2020) ${ }^{56}$. Em geral, todas as organizações artísticas precisavam de estar mais fortes, concentrar diferentes apoios e ligações a instituições e estruturas, que permitam a sua sustentabilidade económica e social, e o desenvolvimento do trabalho artístico de que, afinal, tanto precisamos para dar sentido aos nossos destinos coletivos.

56 Será também importante conhecer os perfis daqueles que assistiram aos espetáculos, ao vivo ou de forma digital, antes e durante a era COVID-19, no primeiro Inquérito Nacional à Participação Cultural da População Portuguesa. O projeto será realizado pela FCG e pelo ICS-UL. Entre outras áreas, serão conhecidos os perfis dos públicos dos espetáculos ao vivo, cinema em sala e festas locais.

\section{O que podemos fazer?}

Ficou demonstrado já, em publicações anteriores, que o trabalho artístico tem vivido muito da extrema flexibilidade do "sistema" e dos seus profissionais (Borges, 2007). Sabemos hoje quais são as vantagens e desvantagens de certos modelos europeus (Menger, 2017). Quando têm trabalho regular, estes profissionais desenvolvem múltiplos projetos e podem acumular ainda as atividades conexas: o ensino, a direção de workshops, entre outros pequenos trabalhos, os chamados "biscates", de onde aliás resulta muitas vezes o sistema de proteção e segurança social que uma parte dos artistas tem. A forte flexibilidade contratual dos profissionais, e, nas duas últimas décadas, a normalização do subemprego nas artes têm produzido situações dramáticas (também do ponto de vista psicológico): até aos 45 anos é considerado normal não ter trabalho regular, parecendo que tudo depende do sucesso individual e das capacidades ilimitadas dos profissionais para gerar o seu próprio emprego. Muitos deles, entre os 20 anos - acabados de sair das escolas superiores - e os 50 anos estão sem trabalho real. Esta situação exige de todos nós o repensar de novas formas de organização e colaboração (v. a interessante reflexão do investigador e programador cultural, A. P. Ribeiro, "até onde os profissionais querem, podem e devem ir") e a ampla discussão pública sobre o valor da arte e as condições da sua concretização ${ }^{57}$.

Cabe-nos repensar novas abordagens e sistemas de proteção social do trabalho nas artes, encorajar o desenvolvimento de formas de suporte e sustentabilidade das organizações e das trajetórias de carreira artísticas. É preciso ver asseguradas

57 Consultar o programa A Arte Custa, que organizo com Luísa Veloso, CIES-Iscte, e Liliana Coutinho, Culturgest, nos dias 14 e 15 de outubro, com uma conferência sobre $\bigcirc$ trabalho dos artistas e as lógicas de (des)profissionalização, onde participam P.-M. Menger e Izabella Wagner. E, ainda, dois workshops: $O$ que vale a arte: as premissas do trabalho artístico e $\mathrm{O}$ que custa a arte: as premissas de organização do trabalho artístico. Disponível em: https://www.culturgest.pt/pt/programacao/arte-custa/?tag=43. 


\section{CADERNOS DAPANDEMIA 0 INSTITUTO DE}

melhores, e mais condignas, condições de trabalho para todos os profissionais. Sabe-se, pelos estudos feitos noutros países europeus, que as estruturas por projeto, mantidas pelos intermitentes, foram soluções extraordinárias para a produção musical (Menger, 2005). Será preservando e fortalecendo diferentes tipo de organizações, que já temos a trabalhar, que conseguiremos um tecido robusto. É importante proporcionar os contextos para a diversificação estética, pois, de outro modo, acabaremos por ter pouca ou nenhuma massa crítica, e, sem diálogo crítico, o tecido artístico perde capacidade para evoluir. É com o trabalho de artistas com diferentes trajetórias que conseguiremos criar uma oferta próxima das pessoas, ora mais popular, ora mais alternativa. O Estado e os municípios dispõem de alguns estudos (embora dispersos e de carácter qualitativo), alguns dados nacionais e projetos de avaliação locais que podem utilizar para equilibrar o mercado de trabalho artístico, sabendo que, em geral, temos um maior número de artistas, com muita qualidade e formação, mais oferta cultural, e, na esfera do debate público, os cidadãos estão cada vez mais atentos à atuação das entidades públicas e são mais interventivos.

De notar que o trabalho nas artes esconde um mundo de profundas desigualdades, que se traduzem, por exemplo, em rendimentos e créditos reputacionais díspares. Daqui resulta a escassez de recursos para alguns e a abundância para outros (Menger, 2012). Mas, apesar disso, as conversas que mantive com diferentes profissionais e os seus depoimentos públicos, durante esta crise, mostram a enorme frustração de todos eles, reputados ou não, considerando que as medidas são insuficientes, de lenta aplicação, e o objetivo comum é aprofundar o sentido da mudança. Ao Estado caberá dar apoio aos indivíduos, através de diferentes tipos de organizações, para criar as condições para que os profissionais possam manter-se a trabalhar. Um tecido com diferentes tipos de organizações, todas elas mais fortes, consegue assegurar uma criação artística plural (Menger, 2005: 62). As organizações permanentes como os teatros nacionais têm a força da sua programação e uma massa crítica muito importante ${ }^{58}$; do lado dos teatros/auditórios municipais, muito está por fazer (Borges, 2019); das instituições e centros coreográficos ressalta a sua inexistência e a luta constante para manter "à tona" estruturas sólidas. A falta de robustez institucional é uma ameaça à criação artística.

Numa conversa com Liliana Coutinho, publicada na Folha de Sala da Culturgest, a coreógrafa Vera Mantero, que fundou O Rumo do Fumo, em 1999, "entra" no seu trabalho de criação para com ele refletir sobre as atuais condições de trabalho dos artistas e o mundo que os rodeia, destacando a importância da "(...) promoção de um contexto social no qual o indivíduo percebe que tem um retorno social que o apoia, que não tem de fazer tudo sozinho, que há mecanismos sociais à sua volta que estão também a cuidar para que não fique desprovido" (novembro de 2019) ${ }^{59}$. Não se pode esquecer o conjunto de organizações que alimentam as artes performativas e vivem dos projetos dos seus artistas, com estruturas ainda desprotegidas do ponto de vista social, institucional, e pela falta de um enquadramento fortalecido pelas políticas culturais. Também no teatro, o modelo das companhias dos anos 70, que há muito tem vindo a desaparecer, deu lugar a estruturas mais ligeiras, mas com condições de trabaIho muito pouco seguras. São estas estruturas que tendem a manter ativo o mercado, alimentando a programação intensa de outras estruturas, promovendo atividades artísticas (e lúdicas para diferentes segmentos), apoiando outros artistas e os festivais locais.

58 Ver a interessante entrevista do encenador e realizador Jorge Silva Melo (05.08.2020) que, à luz da sua trajetória de carreira, analisa a atual situação dos artistas e dos teatros, e como diferentes organizações dependem umas das outras. Disponível em: https:/WwW.rtp.pt/play/p6646/ e487128/grande-entrevista.

59 Disponível em: https://www.culturgest.pt/media/filer public/5b/c2/5bc2b670-911a-459c-848c-e55b7eec2b12/ culturgest_folhadesala_veramantero_web.pdf. 


\section{CADERNOS DAPANDEMIA $\underbrace{0}_{\text {UPORTO }}$ SOCIOLOOGIA}

\section{Estruturas organizativas dos profissionais: até onde conseguem ir?}

Ao longo da era COVID-19, o poder corporativo das estruturas organizativas como o Cena-STE (Sindicato dos Trabalhadores de Espetáculos, Audiovisual e Músicos) fez-se sentir e a sua intervenção intensificou-se: "os apoios não chegaram a todos"60. Fica, ainda, a nota sobre a forte contestação e a desconfiança perante alguns apoios públicos de emergência que os profissionais consideraram erros de avaliação da situação pelo tipo de apoio e pela forma como seria colocado em prática. Ainda a referência a situações extremas, devastadoras, tratadas em reportagens e entrevistas televisivas: "Há atores a passar fome em Portugal"61. Por seu turno, ao longo destes meses, ressaltou a ação muito forte da Rede - Associação de Estruturas para a Dança Contemporânea, e o movimento UNIDXS — Unidos pela cultura em Portugal. Estes questionaram o Ministério da Cultura, no âmbito dos apoios anunciados no Programa de estabilização económica e social (linhas de apoio à adaptação de espaços às medidas COVID-19, linhas de apoio a equipamentos culturais independentes, linha de apoio social aos artistas, autores, técnicos e outros profissionais das artes) que consideram não ser um reforço de verbas, mas antes cortes noutras áreas da cultura, como o programa comunitário Cultura para Todos, que faz o financiamento de projetos no âmbito dos Programas Operacionais de Portugal 202062. A estrutura

60 Disponível em: https:/www.publico.pt/2020/05/05/culturaipsilon/noticia/covid79-sindicato-sai-reuniao-ministra-cultura-certezas-garantias-1915236

61 Disponível em: https://sicnoticias.pt/cultura/2020-07-31-/ncomoda-me-haver-pessoas-que-estao-a-passar-mal-a-entrevista-a-ministra-da-Cultura. Para acompanhar a situação da cultura e as mensagens oficiais do Ministério, ver https:// www.culturacovid19.gov.pt/. Para conhecer os resultados preliminares do inquérito ao "Impacto da crise no setor cultural português", realizado pelo Observatório das Políticas de Comunicação e Cultura, da Universidade do Minho, ver: http://polobs.pt/wp-content/up/oads/2020/03/ESTUDO-COVID-19-ATUALIZA\%C3\%87\%C3\%830-1-QUESTION\%C3\%8TRIOS1.pdf.

62 Estes projetos são dinamizados pelas comunidades intermunicipais e pelas Áreas Metropolitanas de Lisboa e Porto em parceria com organizações artísticas locais.
Acesso Cultura chamou também a atenção para a importância e urgência do envolvimento da sociedade civil nas decisões tomadas pelo Ministério da Cultura $^{63}$. Notou-se, por seu turno, que os profissionais valorizaram o grupo de trabalho que reúne os Ministérios da Cultura, do Trabalho, Solidariedade e Segurança Social e das Finanças para o estudo das condições laborais e carreiras contributivas dos trabalhadores da cultura e pela possibilidade de se pensar, de forma concreta e eficaz, modelos e sistemas de apoio social que, a longo prazo, criem trajetórias de carreira artística fortes e sustentáveis.

\section{Como é que as políticas públicas enfrentam e gerem esta crise?}

O chamado Universal Basic Income (UBI) foi acionado pela generalidade dos países europeus, durante a era COVID-19. Espanha tem um plano para fazer entrar em vigor o UBI e, no Reino Unido, os partidos estão a confluir no mesmo sentido. Os esquemas de compensação, que já existem na Europa, são burocráticos e têm problemas sérios por resolver (Menger, 2017). Com os nossos perfis de organizações, tão heterogéneos, podemos ter dificuldade em criar padronizações ${ }^{64}$. Por agora, no nosso país, destaca-se a Linha de Apoio de Emergência para as Artes (por meio do Fundo de Desenvolvimento Cultural), criada pelo Ministério da Cultura para apoiar as artes cénicas, as artes visuais e interdisciplinares. Os apoios foram para as instituições culturais (20.000 euros, no máximo, por entidades e 2.500 euros, no máximo, para cada artista). O Fundo da Fundação Calouste Gulbenkian também se destinou a um apoio de

63 Ver ainda o projeto que Maria Vlachou, diretora executiva da Acesso Cultura, integra: "Reshape, imaginar alternativas" (como pode a arte ajudar-nos a pensar novas formas de intervenção e cidadania ativa). Disponível em https:/ reshape.network/article/the-department-for-civil-imagination-an-institution-for-reshaping-realities-in-poetic-practical-and-political-ways.

64 Ver Compendium of Cultural Policies and Trends. Comparative overview: financial measures and COVID-19. Disponível em: https://WWw.culturalpolicies.net/COVID-19/comparative-overview-financial/. 


\section{CADERNOS DAPANDEMIA $\underset{\text { SOCLIOLOGIA }}{\mathrm{INSTITUTO}}$}

emergência nestas áreas artísticas, sob a forma de reposição parcial de lucros e a contribuição para a continuidade de pequenas empresas do sector cultural. A Fundação promoveu ainda Bolsas para novos criadores no cinema, dança e teatro, em particular, para os trabalhadores independentes. A GDA - Gestão dos Direitos dos Artistas também disponibilizou um fundo para garantir as "necessidades essenciais" dos artistas independentes e trabalhadores das estruturas ${ }^{65}$. Por sua vez, na Grécia, os trabalhadores freelancers e trabalhadores ocasionais nas artes que foram afetados, podem pedir um subsídio único, que não servirá para aqueles que tinham rendimentos regulares no setor, antes da pandemia. No Reino Unido, o governo conservador desenvolveu medidas de emergência fiscal para proteger o mercado e disponibilizou apoios na ordem dos $80 \%$ (semelhante à Itália e à Eslovênia), tanto a trabaIhadores assalariados como aos trabalhadores por conta própria. Em França, por exemplo, a Adami - Organização de gestão coletiva para os direitos dos performers, criou uma medida de auxílio financeiro, mantido para projetos artísticos cancelados ou adiados e anteriormente apoiados pela Adami, com o foco na remuneração dos artistas. Esta instituição foi, ainda, responsável por medidas de apoio aos artistas, das áreas da dança, teatro e música, que enfrentam situações sociais mais urgentes. Na Alemanha, sublinha-se o Programa de financiamento Take Care, do Fundo das Artes Performativas, para artistas independentes com projetos até 5.000 euros; e a ajuda de emergência da Performing Arts Alliance, no valor de 500 euros, para artistas com necessidades sociais (financiado por doações) $^{66}$. Estes são apenas alguns exemplos.

65 Ver o resumo das medidas no país, https:/ www.cultura/po/icies.net/COVID-19/country-reports/pt/, de Cristina Farinha.

66 Ver o estudo Situation Berliner Künstler*innen und Gender Gap, publicado em 2018, pelo Instituto de Desenvolvimento de Estratégias, de Berlim, onde se analisam as condições de trabalho dos artistas na cidade: para $80 \%$ dos profissionais da cultura e da arte, a atividade exercida era deficitária e apenas $10 \%$ dos envolvidos na pesquisa podiam viver deste trabalho durante o ano. Disponível em: https://www.goethe. de/ins/br/pt/kul/mag/21498392.html.
Para uma grande maioria dos artistas o problema é a falta de rendimentos básicos, e se pensarmos que, até ao fim de 2020, muitos ajustes estão a ser feitos, podemos antever um cenário de grandes dificuldades. Noto que é importante ter em conta as limitações e as diferentes possibilidades dos contextos organizacionais e nacionais, e como isso se reflete na produção das políticas públicas pelos governos e, por fim, nas formas como estas gerem e enfrentam a crise (Kleppe, 2017).

\section{O que se recomenda?}

Saber que os artistas se sentem realizados quando estão a fazer um projeto - como muitos de nós - não justifica que nada se faça no sentido de equilibrar um mercado que precisa de melhores condições de trabalho para todos. Qualquer ideia que possa ajudar a mudar o setor das artes e da cultura a reposicionar-se de forma muito mais forte, após o COVID-19, passa por mostrar as diferenças e as semelhanças deste em comparação com outros mundos sociais. O potencial de mudança nas artes não reside apenas na sua forte dimensão simbólica e de criação de significado, mas, nas possibilidades que oferece para se desenvolver um trabalho significativo e promover a realização do potencial criativo individual e de bem-estar coletivo, num "imaginário" de transformação social criativa que valida as aspirações das pessoas, que valoriza a interligação dos tempos de trabalho, tempos de preparação dos projetos e dos períodos de aprendizagem (Borges, 1992, 2007; Borges e Pereira, 2012), e que promove um futuro viável (O’Connor, 2020; Banks, 2020).

Em momentos de crise, as políticas públicas podem criar a perceção de que estão a provocar o colapso de uma franja de profissionais sem condições de trabalho, a marginalização e a crescente comiseração dos "artistas e estruturas comuns", o que destrói qualquer tentativa de fundar uma comunidade forte e tornar mais solidário este tecido artístico, que é muitas vezes "puxado" por artistas visionários que arriscam e mostram capacidade para promover múltiplas ligações institucionais. Sem dúvida que a era COVID-19 deixou à vista os danos causados pelo 


\section{CADERNOS DAPANDEMIA $\underbrace{0}_{\text {UPORTO }}$ SOCIOLOOGIA}

baixo investimento público nas organizações e nos seus profissionais, fazendo com que estas dependam muito das capacidades heroicas dos artistas e diretores resilientes. Mas, é preciso dar o sinal inequívoco de que a situação é urgente para todos os profissionais e nos diferentes domínios artísticos. Depois, o trabalho por projeto ou as carreiras portefólio não existem só nas artes (Lundi et al., 2015). A autonomia nas relações de trabalho e a realização de si mesmo (Menger, 2005: 21) são importantes para todos nós. Por isso, continuar a tratar o mundo das artes como um mundo social à parte dos outros, um "mundo de vocações" com as quais as políticas públicas não se metem, um mundo com muitos "chamados", mas "poucos escolhidos", não serve para promover a mudanças que as artes e as sociedades atuais precisam. Utilizando os argumentos de Menger (2002, 2014, 2012, 2017) e Banks (2017, 2020), devemos discutir os riscos envolvidos no trabalho artístico, em Portugal, e nos países Europeus, aceitar as vantagens e desvantagens de compartilhar socialmente o risco destas profissões, como de outras; e transformar as ações de apoio urgentes em decisões fortes, que, no médio-longo prazo, são capazes de fazer a mudança.

Por fim, se algum papel podemos ter neste momento, então que seja de chamar a atenção que a arte é um trabalho cuja sustentabilidade deve incluir melhores condições para todos. Nas aulas que dou no Mestrado em Estudos de Teatro, na Faculdade de Letras da Universidade de Lisboa, promovo o espírito crítico e os debates em torno do trabalho no teatro e na dança. Observo o gosto dos estudantes, por exemplo, pela dança social. Mas, ouço continuamente a dificuldade que estes têm em fazer a transição para esses projetos na sua comunidade local. É importante a abertura dos municípios e organizações locais a outras lógicas sociais, comunitárias, feitas com base em alternativas adequadas aos territórios, para aproximar os públicos - com diferentes padrões de consumo - das atividades expressivas, da prática e do consumo regular de atividades artísticas (DiMaggio, 2006; Lopes, 2007, 2019, Borges, 2019, 2020). Seja como profissionais ou como artesãos das artes do espetáculo, não há dúvidas sobre o potencial criativo e social das artes pela possibilidade de envolvência nas comunidades, pelo ativismo e a sua força de atuação contra a gentrificação dos bairros, pela massa crítica que ajudam a construir.

Este conjunto heterogéneo de estudantes e profissionais das artes, que tenho escutado, - atores, encenadores, bailarinos, coreógrafos, diretores de estruturas, programadores, produtores - são a esperança de um tecido artístico mais forte, com trabalho colaborativo real, em diferentes níveis e dimensões. O potencial cultural e o valor intrínseco destas organizações e destes indivíduos são os motores da mudança na direção do bem-estar coletivo. As decisões tomadas agora podem e devem apoiar essa mudança na vida das pessoas, sabendo-se que à vocação e ao trabalho artísticos se impõem a precariedade, as desigualdades de género e raciais, de contratos, rendimentos e oportunidades, as disparidades económicas, sociais e institucionais - paradoxalmente aceites, mas contra as quais todos continuaremos a trabaIhar -, sob os auspícios de organizações que, passados 20 anos, apresentam velhas vulnerabilidades, mas deixam em aberto uma forte discussão pública sobre a urgência de outras alternativas para o seu desenvolvimento futuro.

\section{Outubro de 2020.}

*A autora segue as normas do Acordo Ortográfico da Língua Portuguesa de 1990.

\section{Referências bibliográficas}

Banks, M. (2017). Creative Justice: Cultural industries, work and inequality. Londres: Rowman \& Littlefield.

Banks, M. (2020). The work of culture and C-19, European Journal of Cultural Studies, Vol. 23, 4, 648-654.

Borges, V. (2002). Artistas em rede ou artistas sem rede? Reflexões sobre o teatro em Portugal, Sociologia, Problemas e Práticas, n. 40, 887-106.

Borges, V. (2007). O mundo do teatro em Portugal: Profissão de actor, organizações e mercado de trabalho. Lisboa: Imprensa de Ciências Sociais.

Borges, V. \& Pereira, C. (2012). Mercado, formação e sucesso das carreiras: Actores e bailarinos entre persistência e desilusão. In V. Borges \& P. Costa (orgs.), Criatividade e instituicões: novos desafios à vida dos artistas e dos profissionais da cultura. Lisboa: Imprensa de Ciências Sociais, 61-80. 


\section{CADERNOS}

DAPANDEMIA

Borges, V. \& Lima, T. (2014). Apoio público, reconhecimento e organizações culturais: o caso do teatro, Análise Social, Dossier especial: Desvendando o teatro: criatividade, públicos e território, no 213 , xlix (4.ํ), 926-952.

Borges, V. (2017). Cultural organizations, collaborative contexts and public: how they become small communities, PJSS, 16:3, pp. 359-76. Doi: 10.1386/pjss.16.3.359_1.

Borges, V. (2018). Arte colaborativa. Uma observação localizada do teatro e dos seus públicos, Etnográfica, 22 (2): 453-476.

Borges, V. (2019). Políticas públicas para a cultura e a gestão dos equipamentos culturais: o caso do Teatro Nacional D. Maria II em Lisboa, Revista Sociologia, Problemas e Práticas (aceite para publicação).

Borges, V. (2019). Paradigmas das políticas públicas para a cultura e os equipamentos culturais: cinco micro-estudos sociológicos, Reports. Lisboa: D'C-Iscte, 103 págs.

Borges, V. (2020). Robert A. Stebbins: Arts Nonprofits: Associations and Agencies - A Literature Review, Voluntas - International Journal of Voluntary and Nonprofit Organizations. Disponível em: https://doi.org/10.1007/s11266-020-00262-1

Borges, V. \& Veloso, L. (2020). Emerging patterns of artistic organizations in Portugal: A three case studies analysis, Sociologia del Lavoro, vol. 157: 84-107.

DiMaggio, P. (2006). Nonprofit organizations and the intersectoral division of labor in the arts. In W. Powell \& R. Steinberg (Eds), The Non-profit Sector - A Research Handbook. New Haven-London: Yale University Press: 432-461.

Garcia, J. L., Lopes, J. T., Martinho, T. D., Neves, J. S., Gomes, R. T., Borges, V. (2018). Mapping cultural policy in Portugal: From incentives to crisis. International Journal of Cultural Policy, 24:5, 577-593.

Kleppe, B. (2017). Theatres as risk societies: Performing artists balancing between artistic and economic risk. Poetics, vol. 64: 53-62. DOI: doi.org/10.1016/j.poetic.2017.08.002.

Lopes, J. M. T. (2007). Da democratização à democracia cultural: uma reflexão sobre políticas culturais e espaço público. Porto: Profedições.

Lopes, J. M. T. (2019). Recepção cultural e contra-públicos: algumas notas para uma possibilidade de acção. In Teatro Meia Volta. O público vai ao teatro: encontros sobre políticas da recepção e envolvimento de públicos no contexto das artes performativas. Maia: Maiadouro: 58-65.

Lundi, R.A, Arvidsson N., Brady T., Eskstedt E., Midler C., Sydow J. (2015). Managing and working in project society. Cambridge: Cambridge University Press.

Menger P.M. (2002). Retrato do Artista enquanto trabalhador. Lisboa: Roma Editora.

Menger, P.M. (2005). Profession artiste. Extension du domaine de la création. Paris: Textuel.

Menger P.M. (2012). Talent and inequalities: what do we learn from the study of artistic occupations. In: Borges V. e Costa P. eds, Criatividade e Instituições. Novos desafios à vida dos artistas e dos profissionais da cultura. Lisboa: ICS, 49-75.

Menger P.M. (2014). The Economics of Creativity. Art and achievement under uncertainty. Harvard: Harvard University Press.
Menger, P.M. (2017). Contingent high-skilled work and flexible labor markets. Creative workers and independent contractors cycling between employment and unemployment. Swiss Journal of Sociology, 43 (2): 253-284.

Neves, J. S., Azevedo, J., Gomes, R. T., Lima, M. J. (2017). Estudo Posicionamentos das entidades artísticas no âmbito da revisão do modelo de apoio às artes. Lisboa: DGArtes e CIES-Iscte.

O'Connor, J. (2020). Art and culture after COVID-19. Disponível em: https://wakeinalarm.blog/2020/04/09/art-and-culture-after-COVID-19/

Rego, R. \& Borges, V. (2020). The transformative role of Angels' cultural organisations under austerity, em avaliação.

Ribeiro, A. P. (2010). Por onde começar?, Jornal Público. Disponível em: https://www.publico.pt/2020/05/27/culturaipsilon/opiniao/onde-comecar-1917975.

Tsioulakis, I., Fitzgibbon, A. (2020). Performing artists in the age of COVID-19: A moment of urgent action and potential change. Disponível em: http://qpol.qub.ac.uk/performing-artists-inthe-age-of-COVID-19/ 


\section{CADERNOS DAPANDEMIA

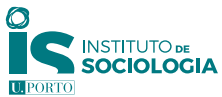

\section{POLÍTICA E TRABALHO NO SECTOR DO CINEMA E AUDIOVISUAL EM CONTEXTO PANDÉMICO: VELHAS TENSÕES, NOVOS PROTAGONISTAS}

Tânia Leão*

\section{Resumo}

Com o eclodir da pandemia da COVID-19, o sector do cinema e audiovisual nacional estremeceu. Os projetos de produção foram suspensos ou adiados, as salas de cinema viram-se forçadas a encerrar portas, os festivais de cinema e restantes eventos cinematográficos foram cancelados ou convertidos em experiências virtuais. Inevitavelmente, as estruturas e a força de trabalho envolvidas na criação/produção, distribuição e exibição de cinema viram a sua precariedade e fragilidade expostas. O texto procura analisar o modo como as velhas tensões constituintes da área - nomeadamente a relação com a tutela - se mantiveram inflamadas durante este período, em que não há apoios que pareçam mais do que remendos para reparar um sector em agonia. Com recurso a bibliografia entretanto produzida e a um conjunto de testemunhos, recolhidos especificamente para a produção deste texto, procurou-se identificar os principais desafios que têm sido colocados ao sector, com particular incidência nas questões laborais.

Palavras-chave: COVID-19; cinema e audiovisual; políticas públicas; precariedade laboral.

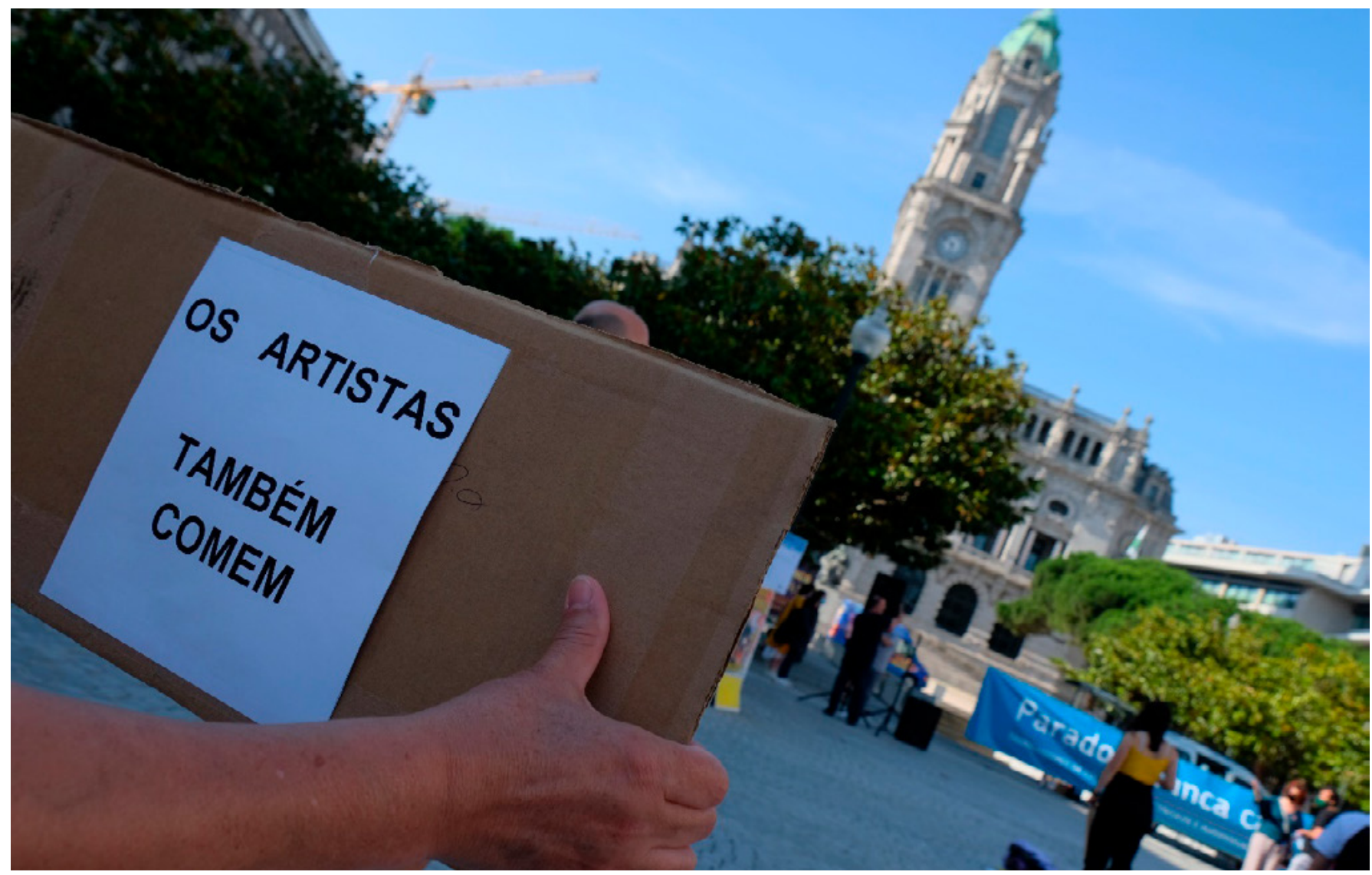

Figura 1 - Manifestação 'Parados, nunca calados' na Avenida dos Aliados, Porto. Manifestação convocada pelo CENA-STE e realizada no dia 4 de junho, no Porto e em Lisboa · (Pedro Ferreira ( 2020) 


\section{CADERNOS DAPANDEMIA $\underbrace{0}_{\text {UPORTO }}$ SOCIOLOOGIA}

\section{O papel do Estado no 'Cinema português'}

A História recente do cinema nacional, das suas estruturas e modos de produção, é indestrinçável da ação e interposição do Estado português no seu desenvolvimento. Nas quase cinco décadas que nos separam do primeiro ato que oficializou a intervenção estatal no sector do cinema português, sucederam-se organismos públicos criados para representarem o Estado na aplicação das diversas medidas destinadas ao sector: Instituto Português de Cinema (IPC) ${ }^{67}$, Secretariado Nacional do Audiovisual (SNA) ${ }^{68}$, Instituto Português da Arte Cinematográfica e Audiovisual (IPACA $)^{69}$, Instituto do Cinema, Audiovisual e Multimédia $(\text { ICAM })^{70}$ e Instituto do Cinema e do Audiovisual (ICA $)^{71}$. A sucessão de organismos a tutelar o sector espelha bem a sua rápida evolução, que vai condenando à obsolescência os instrumentos legais entretanto produzidos; mas também, reflete como sublinhou Santos (2007), o ritmo acelerado das reconstituições do Estado democrático - a sucessão de Governos Constitucionais, de Ministros(as) e Secretários de Estado da Cultura desde a criação do Ministério correspondente, em 1995 - o que tem interferido, naturalmente, nos vetores que têm orientado as políticas culturais e na própria produção legislativa. As sucessivas alterações na designação do organismo responsável pelas políticas no sector do cinema traduzem, ainda, o esforço

67 Lei n. 7/71, de 7 de dezembro.

68 Instituído pela Resolução do Conselho de Ministros n.ำ 2/90, de 10 de fevereiro.

69 Criado pelo Decreto-Lei n. 25/94, de 1 de fevereiro.

70 Decreto-Lei n. 408/98, de 21 de dezembro. Quatro anos após a sua criação, o IPACA e os objetivos definidos para o Instituto foram considerados "ultrapassados", devido à "reconhecida convergência dos sectores do cinema, do audiovisual e do emergente sector do multimédia resultante das transformações tecnológicas em curso".

71 O Decreto-Lei n.․ 95/2007 de 29 de março conduziu à reestruturação e substituição do ICAM pelo Instituto de Cinema e do Audiovisual, I.P. (ICA, I.P.). A alteração mais visível, neste caso, consistiu no desaparecimento do "Multimédia" da nomenclatura do organismo público, por se considerar que o conceito passou a ser demasiado amplo e transversal a diferentes sectores, e não justificava a manutenção de uma tutela específica. no sentido de aliar o cinema a outras "indústrias de conteúdos", como é o caso das "telecomunicações, publicidade e marketing, sistemas de informação, multimédia analógico e digital, televisão, rádio e imprensa" (Garcia, 2014: 33).

Tomemos como exemplo desta tentativa de aglomeração de áreas tradicionalmente distintas o diploma de 2006, que lançava as bases legais do Fundo de Investimento para o Cinema e Audiovisual $(F I C A)^{72}$. O documento referia-se, explicitamente, a uma estratégia que contemplasse em simultâneo o "cinema-artesanato" e o "cinema-indústria", esquivando-se a privilegiar uma das vertentes em prejuízo da outra. Nele ficou definida uma nova lógica de intervenção no sector do cinema e audiovisual, que passava a integrar duas linhas de orientação distintas: (i) por um lado, o Estado reafirmava a visão protecionista da identidade e cultura nacionais, e a necessidade de promover políticas públicas que subtraíssem os bens culturais à "condição de meras mercadorias" (o apoio público permaneceria assente, como até então, na atribuição de apoios a fundo perdido ao sector); (ii) por outro lado, o fundo de investimento funcionaria como um instrumento de direito privado, com uma participação minoritária do Estado, e teria em consideração "a dimensão económica do sector do cinema e áudio-visual e a necessidade de promover a sua sustentabilidade" (ou seja, no investimento realizado pelo Fundo ficava subentendida a obrigatoriedade de retorno de capital).

Como seria de esperar, com o início da atividade do FICA, em 2007³, as divergências do sector, que já eram conhecidas, evoluíram para a esfera pública. Do lado dos realizadores de cinema nacionais, a Associação Portuguesa dos Realizadores (APR) levantou-se contra a racionalidade subjacente ao FICA e insistiu que o hipotético aumento da base de financiamento não beneficiaria os apoios atribuídos por via de concurso público (sistema privilegiado para o fomento da

72 O FICA foi criado pelo Decreto-Lei n.. 227/2006, de 15 de novembro.

73 É a Portaria no 277/2007, de 14 de março, que aprova o Regulamento de Gestão do Fundo. 


\section{CADERNOS DAPANDEMIA 0 INSTITUTO DE}

dimensão artística do sector). No extremo oposto posicionou-se a Associação de Realizadores de Cinema e Audiovisuais (ARCA), que via no FICA uma possibilidade de diversificar as fontes de financiamento e uma forma de promover a consolidação de uma indústria do cinema em Portugal (Gomes et al., 2005: 6).

Em março de 2010 - já com o ICA a tutelar o sector - era lançada uma petição, o 'Manifesto pelo Cinema Português', que tinha como autores e signatários alguns dos mais destacados realizadores e produtores nacionais. ${ }^{74} \mathrm{O}$ texto espeIhava a indignação dos agentes ligados ao sector, que sempre exigiram a separação entre cinema e audiovisual e defenderam a libertação do sector das amarras do mercado: algo que Eduardo Prado Coelho, há mais de trinta anos, já descrevia como a "antiquíssima discussão entre o cinema como arte e o cinema como indústria, entre o cinema como escrita e o cinema como espectáculo" (Coelho, 1983: 10). Debate que, volvidos tantos anos, não deu ainda sinais de se encontrar esgotado e que, aliás, faz parte da essência do que é o cinema português - o que muda são "os termos do debate" (ibid.).

Depois deste episódio, na Lei do Cinema de $2012^{75}$, ficou regulamentado que as fontes de financiamento para o cinema e audiovisual passariam a contemplar os diferentes operadores de televisão e de telecomunicações, incluindo os operadores de serviços de televisão por subscrição. A contestação à Lei de 2012 foi de novo muito grande, em particular entre os operadores privados, que consideraram o diploma inconstitucional e à revelia do direito europeu. A proposta regulamentar de 2012 acabou por ser revista, devido à recusa dos operadores de televisão por subscrição em pagar,

$74 \bigcirc$ texto do Manifesto encontra-se disponível em: http:/ Www. peticaopublica.com/pi=P2010N1571. Entre os realizadores que o apoiaram, encontravam-se nomes consagrados e jovens realizadores em vias de consagração, como Manoel de Oliveira, Fernando Lopes, Paulo Rocha, Alberto Seixas Santos, Jorge Silva Melo, João Botelho, Pedro Costa, João Canijo, Teresa Villaverde, Margarida Cardoso, João Pedro Rodrigues, Bruno de Almeida, Catarina Alves Costa ou João Salaviza.

75 Lei n.․ 55/2012 de 6 de setembro. às consequentes dívidas geradas e ao perigo de paralisação dos apoios à produção cinematográfica nacional, e a iniciativa do FICA foi dada como concluída em 2014.

O financiamento do ICA não depende do Orçamento de Estado, antes advém de receitas próprias (algo que foi por várias vezes sublinhado nos últimos meses). Como ficou expresso na letra da Lei do Cinema de 2012, revista pela Lei 28/2014, as receitas do ICA provêm de uma Taxa de Exibição (que incide na publicidade comercial exibida no cinema, na televisão e nos serviços audiovisuais a pedido) e de uma Taxa de Subscrição (que obriga os operadores de serviços de televisão por subscrição a uma taxa anual por cada subscrição de acesso aos serviços). Os valores provenientes da cobrança destas taxas são receitas do ICA, e ainda, em menor escala, da Cinemateca. A estas taxas acrescem obrigações de investimento no fomento e desenvolvimento do sector, a aplicar aos operadores de televisão, aos operadores dos serviços audiovisuais a pedido, ao sector da distribuição e da exibição. Com a rápida reconfiguração das fontes previstas para estas receitas, a desobrigação de contribuição dos operadores dos serviços audiovisuais a pedido para o ICA, e a sua não vinculação ao Orçamento de Estado, a sustentabilidade financeira do ICA, estruturalmente débil, fica ainda mais frágil.

A comparação europeia permite-nos verificar que os apoios à criação, distribuição e exibição de cinema nos diferentes países europeus são fundamentalmente públicos, variando apenas os modelos de angariação das verbas para financiamento. As verbas podem ser provenientes, por exemplo, da taxação de receitas publicitárias ou de taxas cobradas a meios de comunicação social e/ou a operadores de telecomunicações (Portugal, Itália, Inglaterra ou Polónia), ou de uma percentagem dos lucros da lotaria (Inglaterra ou Finlândia). As atividades cinematográficas em países como a Hungria, a França, a Finlândia e a Holanda, podem ainda ser objeto de outros apoios, como é o caso de benefícios fiscais diretos (para produtores e distribuidores) ou indiretos (benefícios fiscais com incidência no preço dos bilhetes de cinema) (Garcia, 2014: 39). 


\section{CADERNOS DAPANDEMIA

Em plena pandemia, quando já muito se escreveu sobre as repercussões que podem ser esperadas para o domínio das artes e da cultura (Banks, 2020; Cabrera, 2020; Kern, 2020), a Plataforma do Cinema ${ }^{76}$ veio contestar a intenção da Secretaria de Estado do Cinema, Audiovisual e Media (SECAM) de discutir e votar a Proposta de Lei n.-44/XIV, que visa transpor a Diretiva Europeia 2018/1808, relativa aos Serviços de Comunicação Social Audiovisual, por considerar que a mesma permitirá "que - ICA se torne num Instituto esvaziado orçamentalmente"'(AA.VV., 2020). O desconforto causado pelo facto de a diretiva beneficiar plataformas como a Amazon, a Disney Plus, a HBO e a Netflix, e de, ao fazê-lo, subtrair fontes de financiamento basilares para o fomento do cinema português, criou as condições para que uma carta aberta, intitulada "Pelo Cinema Português", reunisse cerca de 900 assinaturas de profissionais da área. Este tem sido, inequivocamente, um período atribulado para o sector, com múltiplas reivindicações e frentes de batalha. As circunstâncias dramáticas geradas pela pandemia e a associação das dificuldades vividas pelos(as) trabalhadores(as) da área com novas ações legislativas, redundaram em vários protestos públicos. Nos últimos meses, assistiu-se a manifestações, cartas abertas, petições e abaixo-assinados, onde o sector do cinema tem sido, juntamente com o das artes de palco (e como vem sendo habitual), um dos mais visíveis e com mais reverberação junto dos meios de comunicação social e dos decisores políticos. Há, no entanto, uma nuance distinta e digna de nota, como veremos ao longo do texto: o aparecimento de novos protagonistas, de novas vozes - como, por exemplo, dos(as) técnicos(as) e estudantes do sector - que têm contrariado a tendencial convergência da discussão na esfera da criação e, desse modo, contribuído para alargar os termos do debate.

76 A Plataforma do Cinema é constituída pelas seguintes entidades: Agência da Curta Metragem, Apordoc - Associação pelo Documentário, APR - Associação Portuguesa de Realizadores, Casa da Animação, Curtas Vila do Conde, Doclisboa, IndieLisboa, Monstra - Festival de Animação de Lisboa, PCIA - Produtores de Cinema Independente Associados, Porto/Post/Doc, Portugal Film e Queer Lisboa.

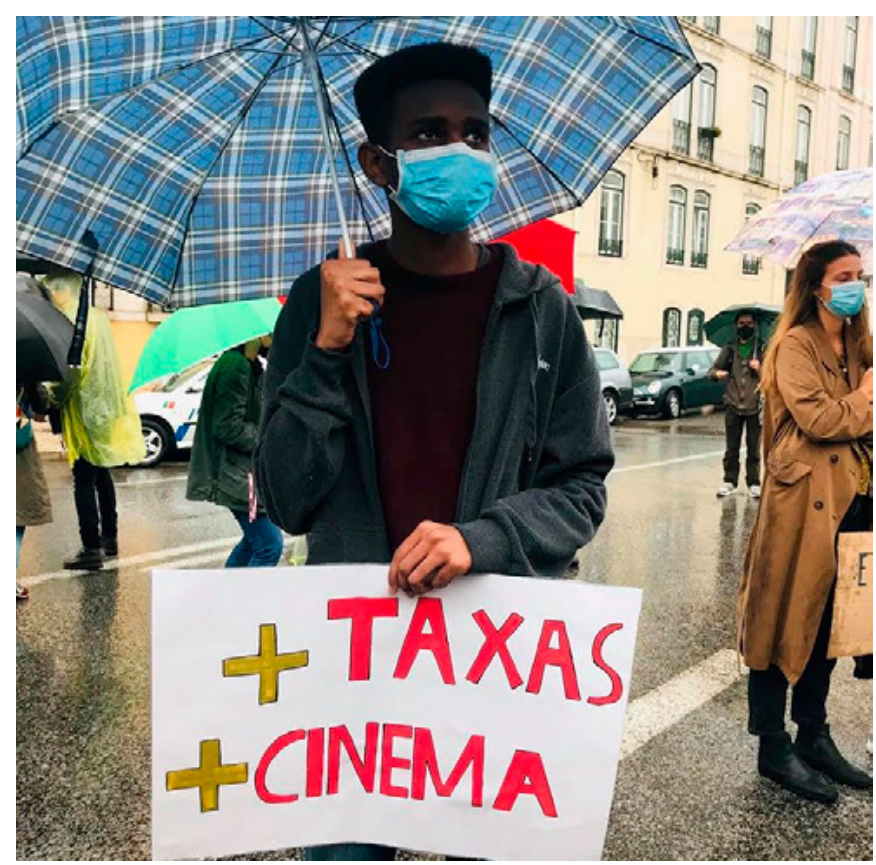

Figura 2 - Manifestação do Movimento Estudantil Pelo Cinema Português em frente à Assembleia da República. 20 de outubro de 2020.

(Fotografia cedida por Raquel Freire. Autor/a Desconhecido/a (c) 2020)

\section{II. $O$ que tem faltado à discussão?}

Os debates no sector do cinema em Portugal têm sido marcados por divergências e 'lutas' internas, típicas de um mercado pequeno, com um potencial concorrencial estrangulado à partida, onde se esgrimem argumentos (económicos, político-ideológicos e estéticos) sobre qual deverá ser o papel e a política desenvolvida pelo Estado português. Trata-se, no fundo, de diferentes variantes da anciã - e legítima - discussão, já aflorada, sobre o grau de interpenetração admissivel entre os campos artístico e económico, ou sobre até que ponto fará sentido pensar-se numa 'indústria de cinema' em Portugal.

Por conseguinte, dir-se-ia que existem dois aspetos recorrentemente subalternizados neste debate. 


\section{CADERNOS DAPANDEMIA SOCIOLOGIA}

(i) O sector do cinema é constituído por diversas dimensões, interdependentes, que compõem a sua 'cadeia': a criação/produção, a distribuição, a exibição e o consumo cinematográficos. Contudo, a constante escassez de financiamento da entidade que tutela o setor, tem levado a que o foco do debate público se cinja excessivamente à esfera da criação/produção - o que não cumpre com a amplitude que devem assumir as políticas públicas para o cinema.

O recente relatório sobre o Estado da Nação e as Políticas Públicas enfatiza a importância das políticas de apoio às artes (Neves, 2020: 26-32). O documento destaca que a despesa pública em cultura, em Portugal, mantém-se abaixo da média dos países da União Europeia (UE). O domínio cultural, ao ser amplo, heterogéneo e particularmente frágil, leva a que as diretrizes de política pública sejam determinantes a vários níveis: na gestão pública de equipamentos culturais; no apoio a entidades privadas (maioritariamente, associações sem fins lucrativos) que oferecem serviços públicos que o Estado não consegue garantir; e na regulação do mercado. Têm ainda como função proporcionar ao conjunto da população portuguesa a possibilidade de aceder a produtos culturais diversos: um dos principais propósitos das políticas públicas consiste em contribuir para o esbatimento de assimetrias territoriais, socioeconómicas e educacionais. Portugal é um dos países da UE em que o acesso a atividades culturais é mais baixo; e um dos países em que os hábitos de participação cultural são mais lassos. Todas estas são tendências que urge combater.

No caso do cinema, as dimensões da difusão e fruição têm sido secundarizadas, apesar de paulatinamente resgatadas pelos apoios que o ICA tem vindo a introduzir. No âmbito da exibição de cinema, por exemplo, tem-se verificado uma propensão para a concentração dos apoios na realização de grandes eventos cinematográficos nos principais polos urbanos do país, o que tem esvaziado pequenas e médias iniciativas verdadeiramente descentralizadas (e que já têm existência real mormente os cineclubes), e contribuído para fragilizar ainda mais o tecido de exibição alternativa de cinema (Leão, 2019). Por outro lado, o trabalho pedagógico de sensibilização para a fruição de cinema e de formação de novos públicos (onde se inclui o Plano Nacional de Cinema) tem sido menorizado. Existem sinais de que esta tendência pode estar a mudar, mas esta é uma discussão que não tem sido cabalmente realizada pelos agentes do sector.

(ii) A discussão alargada sobre as condições de trabalho no sector foi precipitada pela pandemia. Contudo, é raro fazer-se este debate. Em parte, pela razão apontada no ponto anterior: a focalização excessiva na esfera da criação/ produção secundariza os aspetos relacionados com a forma como, na prática, trabalham as pessoas que tornam possível a criação, produção, distribuição e exibição de cinema no país. Adivinha-se, por um lado, uma certa resistência - no cinema como noutras esferas culturais - para admitir e lidar com a assunção da proletarização desta classe de trabalhadores. À semelhança do que, em tempos, André Gorz (1976) referia em relação aos trabalhadores da ciência, há um certo grau de materialidade no trabalho proletário que, ainda que inconscientemente, o trabalhador das artes tende a não compatibilizar com a realidade do seu ofício que supõe intelectual, imaterial e inefável.

Há ainda a inclinação para se reproduzir e exponenciar (discursivamente e na prática), a dimensão não pecuniária do trabalho no sector, optando-se por realçar aspetos "atrativos" como o estatuto, a reputação, a gratificação afetiva ou a possibilidade de acumulação de capital social e simbólico (Menger, 2002), e evitando-se referir os constrangimentos financeiros, a falta de perspetiva de carreira ou a desproteção social. Porém, este ethos que anima a existência dos trabalhadores das artes e da cultura - o que normaliza a precariedade e o trabalho não pago, e glorifica a flexibilidade e a ausência de rotina como formas de 'libertação' da produção massificada e do capitalismo - é, como salienta Lloyd (2010), terreno pantanoso, já que as características que definem a 


\section{CADERNOS DAPANDEMIA 0 INSTITUTO DE}

\begin{abstract}
"ética e o espírito de flexibilidade" próprios da prática artística são integralmente compatíveis com o espírito do capitalismo neoliberal, reforçando-o e alimentando-o (ao invés de o contrapor). Ao mesmo tempo, contribui para que perdure, entre os(as) próprios(as) trabalhadores(as), um desconhecimento gritante dos seus direitos laborais e dos instrumentos ao seu dispor para os preservar. Assim sendo, este é mais um fundamento que se impõe ultrapassar, para que a dimensão do trabalho, em toda a sua complexidade, passe a ser uma presença constante nas reflexões sobre o sector.
\end{abstract}

\section{A pandemia que levou à paralisação: trabalho e precariedade}

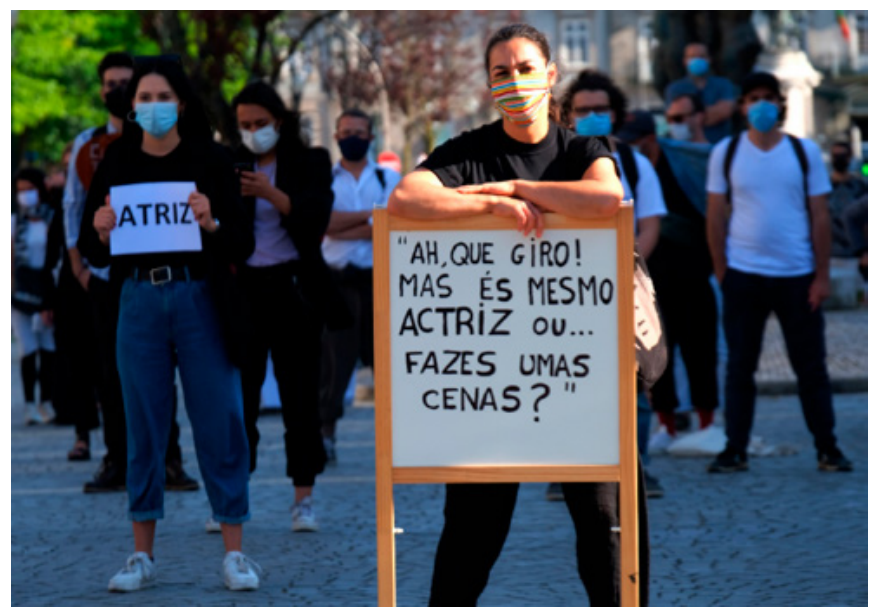

Figura 3 - Manifestação 'Parados, nunca calados' na Avenida dos Aliados, Porto. Manifestação convocada pelo Cena-STE e realizada no dia 4 de junho, no Porto e em Lisboa.

(Pedro Ferreira (c) 2020)

A 26 de abril de 2020, a Plataforma do Cinema alertava, num comunicado, para a situação "calamitosa" vivida pelo sector. ${ }^{77}$ Com o eclodir da pandemia, sucederam-se acontecimentos que conduziram à sua paralisação quase total: várias produções foram suspendidas ou adiadas; as salas de cinema foram encerradas sem previsão de reabertura (e sem se

77 Disponível em: http:/ www.apordoc.org/?p=862 saber se, ao reabrirem, a afluência de público iria equiparar-se ao período pré-pandémico); e milhares de profissionais da área (precários, trabalhadores sazonais, trabalhadores intermitentes ou a projeto) ficaram sem trabalho e sem qualquer tipo de remuneração. Mais grave ainda, estes trabalhadores, na maioria dos casos, não reuniam os requisitos indispensáveis para poderem beneficiar do Apoio Extraordinário à redução de atividade económica dos trabalhadores independentes disponibilizado pela Segurança Social, ficando assim totalmente desamparados. Em reunião com o SECAM e com o presidente do ICA, os representantes da Plataforma do Cinema sugeriram a execução urgente de três medidas de intervenção pública, com vista a mitigar o impacto nefasto da pandemia: (i) a implementação de um fundo de emergência para os trabalhadores do sector; (ii) a criação de um plano de contingência, com a duração de dois anos, para as entidades que nele laboram; (iii) e o restabelecimento do protocolo de colaboração entre a RTP e o ICA, que previa a atribuição, pela RTP, de um complemento financeiro automático aos projetos apoiados pelo ICA. Nenhuma destas propostas foi atendida pelos representantes do Estado, o que levou a Plataforma, no referido comunicado, a fazer acusações de "inação" e a denunciar a "absoluta irrelevância política do Ministério da Cultura e da recém-criada Secretaria de Estado do cinema e do audiovisual".

Segundo o Observatório Europeu do Audiovisual (Cabrera et al., 2020), as medidas acionadas para responder à COVID-19 pelos 41 Estados-membros que pertencem a esta entidade, foram de dois tipos principais: (i) medidas específicas para o sector do cinema e audiovisual; (ii) e medidas mais amplas, pensadas para o Sector Cultural e Criativo (SCC). As medidas específicas passaram pela criação de novos fundos de emergência a fundo perdido, pela flexibilização dos requisitos de acesso para apoios já existentes, pelo adiantamento de tranches de financiamentos, pelo apoio a artistas e criadores, pela oferta gratuita de serviços ou pela promoção de boas práticas. Já as medidas mais amplas (podendo atravessar setores de atividade distintos) consistiram em apoios para Pequenas e Médias Empresas (PME), e em 


\section{CADERNOS DAPANDEMIA $\underbrace{\text { SNSTITUTODE }}_{\text {OUPORTO }}$ SOCIOLOGIA}

medidas direcionadas para os trabalhadores (com vínculo contratual e freelancers).

Em Portugal, as medidas específicas de apoio ao sector $^{78}$ postas em prática pelo ICA visaram manter, e, sempre que possível, acelerar e flexibilizar, os procedimentos de concessão de apoio cinematográfico e audiovisual..$^{79} \mathrm{~A}$ partir de março, foram sendo tornadas públicas, e permanentemente atualizadas, as medidas excecionais de apoio, a aplicar por período transitório, ao sector do cinema e audiovisual. Entre as medidas avançadas, incluiu-se o fim da obrigatoriedade de a exploração inicial das obras cinematográficas ocorrer em salas de cinema, passando a ser possível que a mesma se dê em televisão ou através dos serviços de comunicação audiovisual a pedido (VOD). Passou a ser possível, por exemplo, o adiantamento de $50 \%$ do valor contratado no Programa de Apoio à Produção. Com o encerramento das salas de cinema, as obrigações de investimento dos exibidores foram suspensas. No Programa de Apoio a Realização de Festivais, permitiu-se a recalendarização das atividades ou o pagamento da atividade do festival, ainda que este tenha sido cancelado. Outras medidas de agilização passavam por admitir planos de atividades apenas parcialmente cumpridos ou a desmaterialização de documentos. Em 28 de abril de 2020, o ICA alertava "para a necessidade de manutenção

78 Alguns exemplos de medidas de maior fôlego para o sector da cultura: o Ministério da Cultura criou uma plataforma que concentra as informações relevantes para os profissionais da cultura, com o objetivo de informar sobre as medidas extraordinárias de apoio (https://WwW.culturacovid19.gov. pt). Foi criada uma Linha de Apoio às Artes com o montante de um milhão de euros, financiada pelo orçamento do Fundo de Fomento Cultural (2.500,00€ por pessoa singular e $€ 20.000,00$ por pessoa coletiva) - valor posteriormente reforçado. Foi ainda criado um fundo de trinta milhões de euros para apoiar a programação cultural a nível municipal. Foram desenvolvidas linhas de crédito para as pequenas empresas fazerem face a despesas fixas durante este período (alguns países europeus - caso da Áustria, Bélgica, Dinamarca e Finlândia, os Países Baixos, entre outros - optaram por, excecionalmente, atribuir apoios a fundo perdido para despesas similares) (Cabrera et al., 2020).

79 As diferentes medidas foram sendo anunciadas no site oficial do ICA: https://WwW.ica-ip.pt/. de obrigações gerais dos beneficiários de apoio, nomeadamente quanto à necessidade de assegurar o cumprimento das obrigações remuneratórias para com o pessoal criativo, artístico ou qualquer outro trabalhador envolvido na execução do projeto". Em agosto, no âmbito do Programa de Estabilização Económica e Social (PEES), aprovou-se um novo conjunto de apoios excecionais, com um montante de $8,5 \mathrm{M} €$, que viriam reforçar os programas de apoio financeiro preexistentes.

Num inquérito levado a cabo, entre 18 e 26 de março, pelo Sindicato dos Trabalhadores de Espectáculos, do Audiovisual e dos Músicos (CENA-STE), respondido por 1300 trabalhadores, concluía-se que $98 \%$ dos inquiridos viram os seus trabalhos cancelados (33\% dos quais por mais de 30 dias) e que $85 \%$ dos respondentes seriam trabalhadores 'independentes', ficando, por isso mesmo, excluídos de qualquer tipo de proteção social. O mesmo sindicato denunciava, ainda, relatos de abusos laborais, como os "lay-offs ilegais" ou a imposição de dias de folga ou férias. ${ }^{80}$

As crescentes dificuldades enfrentadas pelos trabalhadores do sector conduziram ao surgimento de grupos informais de ajuda. A União Audiovisual ${ }^{81}$ foi um desses coletivos, criado com o intuito de angariar e distribuir cabazes alimentares pelos trabalhadores da cultura que enfrentavam situações de privação profunda. Surgiram ainda, nas redes sociais, grupos de entreajuda privados, como o PAF - Prontos a Filmar, cujos membros usam aquele espaço para anunciar a oferta de oportunidades de trabalho ou oferecer os seus serviços. O surgimento espontâneo de tais iniciativas foi revelador de movimentos de solidariedade no sector, mas também das situações extremas que, com o desenrolar da pandemia, se foram tornando públicas.

Vale a pena olhar para alguns testemunhos elucidativos das provações experienciadas:

"Sou trabalhador a recibos verdes. De 15 de março até meio de julho estive sem qualquer

80 http://Www.cena-ste.org/hoticias/arquivo/2020-03. 81 https://uniaoaudiovisual.pt/. 


\section{CADERNOS DAPANDEMIA SOCIOLOCI}

trabalho. Para além de duas produções, em que iria trabalhar como Assistente de Realização (e que foram canceladas), também as filmagens do meu filme foram adiadas. Apesar de já existirem indicações para as filmagens recomeçarem, no caso do meu filme, pela sua vertente documental, continuo impossibilitado de filmar. (...) Recorri ao Apoio Extraordinário de Redução de Atividade, disponibilizado pela Segurança Social. Infelizmente, este apoio esteve durante todos estes meses (até julho) em análise, acabando por ser recusado. A Segurança Social analisou mal o meu caso, o que foi assumido recentemente. Mas este ainda não foi reavaliado. Em suma, ainda não tive qualquer tipo de apoio por parte da Segurança Social. Recorri ainda a um apoio da Câmara Municipal de Lisboa, direcionado aos trabalhadores da cultura. Recebi $€ 430$ em junho. Houve uma injeção de dinheiro do ICA que se traduzirá numa maior produção de obras futuras. Mas, no imediato, os apoios direcionados à minha área foram inexistentes. O único apoio a que os profissionais do cinema (Assistentes de Realização, som, maquinaria, eletricidade, etc.) tiveram ao seu alcance, foi este pequeno apoio da Segurança Social (os que conseguiram). (...) E o apoio da Câmara Municipal de Lisboa, para quem é residente na cidade. Em suma, só os privilegiados, com casa paga ou dinheiro de família, conseguiram subsistir. (...) Os realizadores que apenas vivem da sua própria produção são essencialmente burgueses e a sua subsistência vem de outro lado."

Diogo Allen

Assistente de Realização em Cinema e Realizador de cinema documental (28 julho 2020)

"Estou inscrito como trabalhador independente, o que não reflete a realidade do meu trabalho. Encontro-me muitas vezes a trabaIhar de forma dependente, mas a recibo verde. É por isso que lutamos por um regime específico para os trabalhadores da cultura. Com a pandemia, fiquei sem trabalho. Os meus rendimentos dependem em grande parte da minha atividade de Diretor de Som em filmes e, como os filmes ficaram parados, fiquei sem trabalho. Tive o apoio de quase $€ 400$ euros da Câmara Municipal de Lisboa. Pedi ainda o apoio extraordinário para trabalhadores independentes da Segurança Social e este foi indeferido porque sou membro estatutário de uma associação sem fins lucrativos. Nunca tive rendimentos através da associação.... É absurdo."

\section{Miguel Moraes Cabral \\ Realizador e Diretor de Som na área do cinema (29 julho 2020)}

\begin{abstract}
"Sou trabalhador por conta própria, para uma associação cultural sem fins lucrativos, e também trabalho para outras entidades como freelancer. A pandemia afetou a minha atividade diretamente: todas as atividades que estavam previstas acontecer foram cancelas ou adiadas. A minha situação profissional não cabe dentro de nenhum dos apoios que foram apresentados para enfrentar a pandemia COVID-19. Não recorri a outros apoios. Recorri somente às entidades que tinham compromissos com a minha associação, para exigir que assumissem os valores previstos (pelo menos, dos honorários das equipas). Considero que os apoios extraordinários do Estado foram insuficientes, poucos e tardios. Não contemplaram grande parte dos trabalhadores, devido à informalidade e precariedade dos trabalhos nesta área. A resposta do governo, do Ministério da Cultura, foi sempre de desresponsabilização. Tão grave, que chega a parecer jocosa com os trabalhadores."
\end{abstract}

\section{Sérgio Marques Produtor, programador e criador de eventos em redor do cinema (7 agosto de 2020)}

Os projetos de produção em andamento foram interrompidos e os que estavam em vias de iniciar foram adiados pelo confinamento obrigatório. Esta paragem afetou o conjunto dos(as) trabalhadores: $\operatorname{dos}(a s)$ realizadores(as) às equipas 


\section{CADERNOS DAPANDEMIA 0 INSTITUTO DE}

técnicas e, ainda, aos técnicos(as) provedores dos mais variados serviços (na sua grande maioria, trabalhadores precários). Além das alterações ao Programa de Apoio à Produção do ICA, algumas das estruturas de produção (microempresas e PME) puderam concorrer a apoios específicos. Um desses apoios foi um sistema de incentivos estabelecido em decreto-lei" ${ }^{82}$, o Programa ADAPTAR, que visava apoiar a reformulação da atividade económica às restrições impostas pelo novo contexto (despesas com equipamentos de proteção pessoal e de higienização, com a reorganização dos locais de trabalho, etc.).

"Sou trabalhador por conta própria, com menos de 10 trabalhadores a meu cargo. A pandemia provocou uma impossibilidade total de trabalho em rodagem e de produção de cinema. Recorri apenas aos apoios extraordinários do ICA. Os apoios pecam por tardios, bem como por insuficientes. Acho que não existiu qualquer proteção aos profissionais no nosso sector. E mesmo os apoios a que recorremos, são apoios às estruturas de produção e não aos profissionais do sector. No nosso caso, a produção continuará ao mesmo ritmo. Mas o resultado de exploração em bilheteira foi altamente afetado. No mês de junho, a faturação dos cinemas foi 1\% do mês análogo e, em julho, foi 10\%.... Tenho sérias dúvidas que as coisas voltem aos valores de pré-pandemia."

\section{Rodrigo Areias}

Produtor e Realizador de cinema (7 agosto 2020)

"A pandemia afetou, direta e indiretamente, a minha atividade. Diretamente, porque me obrigou a adiar produções que iriam iniciar no período de maio a julho de 2020. Indiretamente, porque me obriga a ajustar os projetos adiados, designadamente a procurar reforço de financiamentos para fazer face a novos custos na produção cinematográfica. Os efeitos deste

82 Decreto-Lei n. 20-G/2020. novo contexto na produção são: em produção, aumento de custos diretos com as práticas de mitigação do risco de infeção (desinfeção e limpezas de espaços de cena, equipamentos de proteção individual para as equipas, protocolos de segurança, testes, etc.) e aumento de custos relacionados com o aumento dos tempos de rodagem derivados dos novos ritmos de trabaIho que a mitigação dos riscos sanitários impõe. Estima-se que o acréscimo de custos de rodagem para projetos interrompidos ou adiados se situe na ordem dos 25 a 30\%. Recorri apenas a um apoio do Estado, o Programa Adaptar. Neste momento, discute-se um plano de contingência / emergência para a produção cinematográfica e audiovisual, proposto pelas associações de produtores (Produtores de Cinema Independente Associados, Associação de Produtores de Televisão e Associação de Produtores de Cinema e Audiovisual). No campo dos apoios aos profissionais independentes deste sector (técnicos e atores) ainda nada se conhece. O futuro do sector é um futuro cheio de incertezas. A retoma da produção cinematográfica ainda está muito condicionada pela capacidade financeira das produtoras para fazer face aos novos custos de contexto e para conseguir encontrar fórmulas seguras de distanciamento social na prossecução dos trabalhos de preparação e rodagem de um filme ou de uma série. Por outro lado, no campo da distribuição e exibição cinematográfica, os dados já conhecidos sobre a retoma da atividade são aterradores. A questão essencial é saber quanto tempo aguentam distribuidores cinematográficos e, sobretudo, salas de cinema com receitas de exploração ao redor de 5 a 10\% das registadas em período pré-COVID 19."

\section{Luís Urbano \\ Produtor Cinematográfico, Distribuidor Cinemato- gráfico e Empresário (26 julho 2020)}

As salas de cinema estiveram encerradas entre meados de março e o início de junho. Segundo dados divulgados pelo ICA, até setembro de 2020, comparando com o período homólogo do 


\section{CADERNOS DAPANDEMIA 0 INSTITUTO DE}

ano anterior, as salas registaram um decréscimo de $71,1 \%$ de receita bruta e uma diminuição de $71,6 \%$ do número de espectadores ${ }^{83}$.

O encerramento das salas de cinema afetou os distribuidores de cinema, que tiveram de lidar com o prejuízo relacionado com as despesas específicas, técnicas e de marketing, associadas ao lançamento de filmes. Vários distribuidores optaram por libertar diretamente as obras para os serviços de comunicação audiovisual a pedido (VOD), saltando etapas do circuito habitual dos filmes e flexibilizando as janelas de exploração das obras. O relançamento de filmes cuja exploração foi interrompida pode implicar novo investimento em marketing; e o lançamento tardio de filmes em sala irá implicar um constrangimento das receitas, já que a lotação dos espaços foi muito reduzida. A maioria das empresas de produção e de distribuição de cinema e audiovisual são estruturas de pequenas dimensões que trabalham com um número reduzido de obras. Para estas entidades, o confinamento e o período restritivo que lhe seguiu terá, certamente, efeitos bastante penalizadores.

"Sou trabalhador por conta própria, com menos de 10 empregados a meu cargo. Com a pandemia, as salas de cinema estiveram encerradas durante meses. E mesmo agora, com a reabertura, estão praticamente vazias. Ainda existe um efetivo receio de frequentar espaços fechados. Tive de recorrer a apoios extraordinários do Estado, o lay-off e o diferimento de pagamentos. Não recorri a outros apoios, mas é possível que venhamos a beneficiar do reforço dos apoios específicos ao sector, através do ICA. Acredito que os apoios foram os possíveis. Veremos quanto tempo esta crise vai durar, que efeitos estruturais terá no sector, e, portanto, o que mais será necessário."

Luís Apolinário

Sócio-Gerente da Alambique (24 julho 2020)

83 Dados da Newsletter de outubro do ICA. Disponível em: https:/ www.ica-ip.pt/fotos/editor2/news/etter/news_10_2020-1.pdf.
Uma novidade aportada pela pandemia foi a deslocação parcial do debate para a situação concreta vivida pelos trabalhadores do cinema e audiovisual. Subitamente, fizeram-se visíveis e audíveis novos protagonistas, na imprensa e em debates sobre os desafios enfrentados pelo sector. Associações de técnicos, como a Associação de Imagem Portuguesa (AIP) ${ }^{84}$, que reúne os técnicos de imagem cinema e vídeo, ou a recém-formada Associação Portuguesa de Técnicos de Audiovisual (agrupamento informal de técnicos de todos os departamentos do cinema, formalizada em 22 de setembro do corrente ano), fizeram incidir um novo olhar sobre os constrangimentos que infligem o sector.

Ambas as entidades produziram tabelas com valores de referência, por departamento (cinema e publicidade), para serem consultadas pelos técnicos. A APTA criou mesmo o primeiro Guia de Referência de Condições de Trabalho ${ }^{85}$, a aplicar a projetos em múltiplas plataformas ou suportes, como a publicidade, o cinema, as séries ou documentários. A partir da definição das diferentes componentes de um trabalho a projeto - o "tempo de preparação"; as várias modalidades de dias e horários de trabalho; as horas extraordinárias, de descanso, de recuperação e de folga; as refeições; a preparação e utilização de equipamentos; os procedimentos face a adiamentos e cancelamentos; as modalidades de salários e de pagamentos; a proposta de aplicação de um contrato de trabalho temporário, entre outras a APTA procurou delinear as normativas de trabalho essenciais para garantir a qualidade do sector e combater "a degradação das Condições de Trabalho".

Em entrevista ao Fest - New Directors, New Films Festivals, na rubrica 'A Nova Realidade pós COVID-19 - O Estado Atual e Futuro da Indústria do Cinema', Leandro Vaz da Silva, operador

84 htto:/ www.aipcinema.com

85 Disponível em: https://1258339a-81ea-421f-abd1-7141fc6807c8. filesusr.com/ugd/67a9d4_9a45aab79c64482dbd119c5db9a25c53.pdf. 


\section{CADERNOS DAPANDEMIA $\underbrace{0}_{\text {UPORTO }}$ SOCIOLOOGIA}

de câmara e membro da AIP ${ }^{86}$, alertava para o insistente obscurecimento do trabalho técnico nas medidas e protocolos anunciados para combater os efeitos da pandemia. A flexibilização do Apoio à Produção do ICA, por exemplo, 'afunilaria' o apoio à produção, que dificilmente chegaria aos técnicos impossibilitados de trabalhar. Do mesmo modo, os protocolos de segurança adotados tendem a não contemplar os trabalhos desta natureza (não indicam, por exemplo, "como manusear uma câmara em segurança”). Ou seja, as medidas são pensadas de cima para baixo, quando, para serem eficazes, deveriam partir das bases: "como é que [essas medidas] vão chegar a um técnico de efeitos especiais ou a um assistente de guarda-roupa?". A fundamentação para esta dissonância residiria no profundo desconhecimento das entidades oficiais sobre o modo de funcionamento do sector.

Importa atentar nos seguintes testemunhos, fornecidos por um conjunto de técnicas que partilharam as dificuldades que o irromper da pandemia trouxe às suas vidas profissionais e os obstáculos com que esbarraram na procura de apoio financeiro:

"Sou trabalhadora a 'falsos' recibos verdes. Fiz mais de 50 filmes e só houve uma vez em que tive um contrato assinado. No cinema somos pagos à semana. Embora agora haja alguns produtores que tentem, à moda das produtoras para os conteúdos de televisão, pagar ao mês. E as contas que fazem são: um mês é igual a quatro semanas (o que não é correto, como pode perceber olhando para o calendário). A pandemia afetou muito a minha atividade. Tinha uma longa-metragem para iniciar a rodagem a 20 de abril: seis semanas mais duas semanas anteriores de preparação. Num total de oito semanas de trabalho, seis dias por semana e no mínimo $10 \mathrm{~h}+1 \mathrm{~h}$ (hora de refeição) por dia. Horas a mais. No meu sector, não são pagas horas extraordinárias. A rodagem ainda não tem previsão

86 Disponível em: https://www.youtube.com/watch?v=wpcT8F eX 6A. para arrancar. Eu não posso recorrer a qualquer apoio porque, na prática, sou reformada. TrabaIho desde 1973 - no cinema português, desde 1981 - e tenho descontos de 28 anos a recibo verde. Recebo $€ 338$ por mês de reforma. Nunca tive subsídio de férias ou Natal, nem de desemprego ou doença. Há uma tentativa grande de organização que espero que resulte em alguma melhoria. Sou um bocado cética porque, ao longo do tempo, fomos criando associações que foram morrendo. Já houve várias tentativas de melhorar o sector, mas não deram em grande coisa. Geralmente, nas épocas baixas de trabalho, as pessoas reúnem-se e falam das condições de trabalho. E quando o trabalho recomeça, fica praticamente tudo esquecido. Espero que, desta vez, em que a tentativa de organização é mais consistente, algo avance. Foram criadas associações sectoriais e uma associação a APTA -, que abrange todos os técnicos: que, a meu ver, é a que verdadeiramente importa."

Ana Silva

Anotadora de cinema. Passou pela montagem, imagem e foi assistente de Realização (30 julho 2020)

"Trabalhava com a cooperativa Pro Nobis por conta de outrem (a 30\%) e com recibo verde (a 70\%). Estou desempregada desde 1 de junho. Em março, todos os trabalhos que tinha previstos até 31 de julho foram adiados. Em julho, outro trabalho, para uma série, que supostamente estaria a começar em agosto, foi adiado, também indefinidamente. $O$ que fiz foi pedir 0 subsídio de desemprego, ao qual tenho direito por causa do trabalho que faturava com a cooperativa Pro Nobis. Não encontrei nenhum outro apoio em que encaixasse. É impossível sobreviver só com o apoio do Estado."

\section{Fabienne Couvreur}

Pintora-decoradora, ilustradora para cenários de filmes e publicidade (por vezes também teatro e eventos) (29 julho 2020) 


\section{CADERNOS DAPANDEMIA $\underbrace{0}_{\text {UPORTO }}$ SOCIOLOOGIA}

Sou trabalhadora por conta própria, sem outros trabalhadores a meu cargo. Faço também trabaIhos como trabalhadora informal (sem qualquer tipo de vínculo). A pandemia afetou diretamente a minha atividade. Estava a trabalhar como Coordenadora de Produção numa produtora de publicidade a tempo inteiro (como freelancer, mas sem data de saída) e fui enviada para casa. Estive sem qualquer tipo de trabalho durante dois meses. Depois disso, só fiz três trabalhos, de quatro dias cada. Recorri apenas a um apoio do Estado: o apoio aos sócios-gerentes. Os apoios são insuficientes. No meu caso, recebi $€ 438$ por mês, quando só à Segurança Social tenho de pagar $€ 228$ por mês. Este é um sector em que a maioria das pessoas vive com o que ganha no final da semana ou ao final do mês. Com a ausência ou redução drástica do volume de trabalho, tiveram de aprender a recorrer a subsídios, apoios e grupos de ajuda."

\section{Inês \\ Coordenadora de Produção e Diretora de Foto- grafia (29 julho 2020)}

Tudo indica que a pandemia COVID-19 terá um impacto fortíssimo e duradouro no sector do cinema audiovisual. Mediante o contexto alarmante, tanto o sector público como o privado avançaram com iniciativas de auxílio ao sector. $O$ estado, o ICA, entidades reguladoras e diversos stakeholders puseram em campo apoios extraordinários, fundos de emergência, fundos de solidariedade, entre vários outros expedientes (permanentemente reformulados e atualizados), para fazer face à nova conjuntura. O futuro do sector, porém, é olhado com ceticismo pelas várias partes interessadas, que reclamam políticas públicas informadas, sistemáticas e abrangentes.

\section{Conclusão: a exigência de uma política para o cinema que atenda às múltiplas vozes do sector}

Chegados aqui, os trabalhadores que acederam testemunhar sobre a repercussão da COVID-19 na sua atividade profissional, refletiram sobre os principais desafios que anteveem para o sector do cinema e audiovisual. A deterioração das condições de trabalho, a quebra dos incentivos ao sector, a necessidade (urgente) de regulação laboral e de criação de um estatuto específico que confira direitos e proteção social, o receio de uma alteração brusca do paradigma de negócio em virtude da progressiva primazia da produção de conteúdos audiovisuais, foram algumas das inquietações relatadas.

"As rodagens que estão a recomeçar levaram uma grande redução no número dos técnicos contratados. Esta é uma das principais medidas para lidar com a COVID-19 e, também, um dos grandes desafios. Os filmes fazem-se na mesma: com metade das pessoas, trabalhando mais horas e acumulando funções. No meu caso, como Assistente de Realização, é possível eu suportar o trabalho do meu Assistente. Mas isso leva-me a uma maior exaustão e a trabalhar horas para lá do legal. Sei, por vários colegas de profissão, que as produtoras estão a perceber que a coisa funciona assim. Abre-se, então, um precedente que poderá fazer regra no futuro."

\section{Diogo Allen}

Assistente de Realização em Cinema e Realizador de cinema documental (28 julho 2020)

"Sobre o futuro do sector, sinceramente, não sei. Foi prometido pela Ministra da Cultura que iríamos ter um estatuto específico para as nossas profissões até o final do ano. Mas sabemos que pode correr mal, como já aconteceu com a lei 4/2008. Em relação ao trabalho, está a voltar lentamente, mas tudo indica que vai ser pior. Isto porque o orçamento do ICA vai baixar (por causa da sua forma de financiamento, que não depende do Orçamento de Estado, mas das taxas de exibição e da taxa dos serviços de TV por subscrição). O cinema depende do ICA: se houver menos dinheiro no ICA, há menos filmes, portanto, menos trabalho. Com a pandemia ficou ainda mais claro que os trabalhadores do 
CADERNOS

DAPANDEMIA

$\overbrace{\text { IIPORTO }}^{\text {SONTITUTO DE }}$

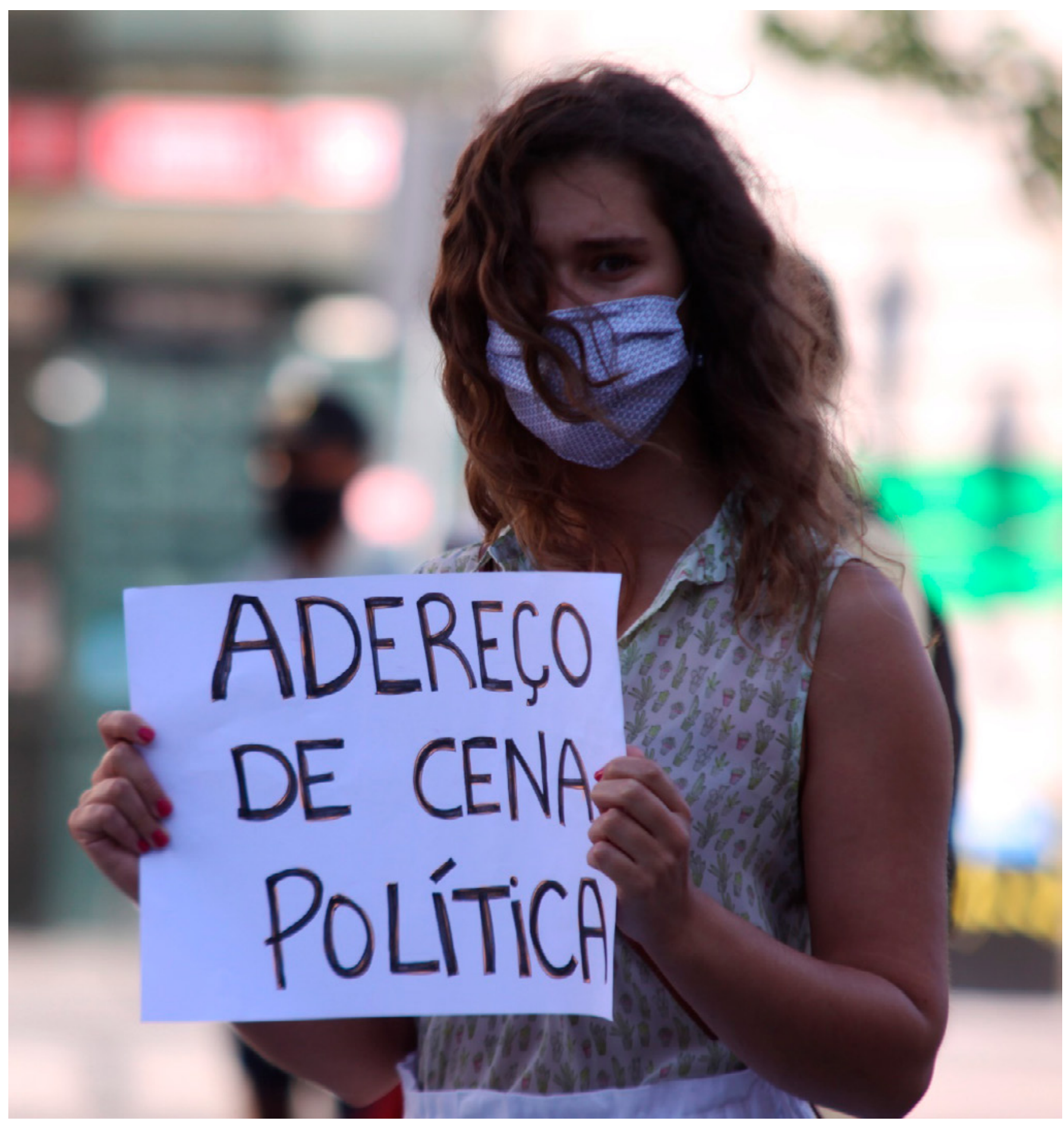

Figura 4 - Manifestação 'Parados, nunca calados' na Avenida dos Aliados, Porto. Manifestação convocada pelo Cena-STE e realizada no dia 4 de junho, no Porto e em Lisboa. · (Pedro Ferreira (c) 2020) 


\section{CADERNOS DAPANDEMIA SOCIOLOCI}

cinema e da cultura estão completamente desprotegidos. Na maior parte dos casos não têm direito ao subsídio de desemprego (a menos que sejam falsos recibos verdes e que concentrem mais de $50 \%$ dos seus rendimentos num único empregador), não existem contratos de trabalho, e os orçamentos são frágeis. O principal desafio que se nos coloca é a regulação do sector e a criação de um regime específico que reconheça a natureza do nosso trabalho, ou seja, a intermitência dos rendimentos e o trabaIho a projeto."

\section{Miguel Moraes Cabral \\ Realizador e Diretor de Som na área do cinema (29 julho 2020)}

"O país tomou consciência da fragilidade do trabalho na cultura com a enorme crise que se notou no cinema e na cultura em geral. Para mim, o grande desafio tem a ver com os direitos laborais dos profissionais que, tal como em muitas outras áreas, terão de estar mais protegidos por via do Código do Trabalho ou outros mecanismos. O cinema em Portugal (tanto a produção como a difusão), está muito dependente dos apoios públicos. Excetuando o cinema comercial, que funciona como qualquer empresa. $O$ grande desafio é perceber se o estado pretende promover a Cultura ou não, que tipo de serviços e que estratégias estão previstas para Portugal após este momento."

\section{Sérgio Marques}

Produtor, programador e criador de eventos em redor do cinema (7 agosto de 2020)

"Neste momento, o maior perigo é o aumento considerável do peso do streaming e do consumo de cinema e audiovisual a partir de casa. $\mathrm{O}$ que tem um problema muito mais grave do que a mera alteração de todo o paradigma de faturação: trata-se da total alteração do modelo de negócio, que ficará refém de estruturas económicas estrangeiras e de uma fortíssima formatação do conteúdo. Deixará de existir cinema e passará apenas a existir produção audiovisual, cujos interlocutores privilegiados são plataformas de formatação de géneros. O perigo é o fim da diversidade cultural que caracteriza o cinema nacional e que o projeta internacionalmente."

\section{Rodrigo Areias \\ Produtor e Realizador de cinema (7 agosto 2020)}

"Outros desafios se colocam ao sector: qual o papel dos festivais de cinema e em que medida poderão contrariar a tentação de saírem do espaço físico para o espaço virtual. O mesmo relativamente à exibição cinematográfica, o mesmo é dizer, em que medida as plataformas de VOD, SVOD, TVOD se tornarão no novo espaço para a estreia de obras cinematográficas. Estas questões irão com certeza colocar-se nos próximos tempos e poderão obrigar a uma mudança radical na área da produção cinematográfica e audiovisual."

\section{Luís Urbano \\ Produtor Cinematográfico, Distribuidor Cinemato- gráfico e Empresário (26 julho 2020)}

"O futuro deste meio será de profunda mudança. Sendo que a dimensão e o sentido dessa mudança são uma enorme incógnita. $\mathrm{O}$ sector já se encontrava debaixo de uma enorme vaga de transformação, com a distribuição e circulação de um cinema mais independente/ alternativo a ser fortemente ameaçada. É muito provável que a pressão exercida pela(s) crise(s) provocadas pela COVID-19 venha amplificar estas tensões."

Luís Apolinário

Sócio-Gerente da Alambique (24 julho 2020)

Em Portugal, um pouco à semelhança do que se tem verificado noutros países europeus, uma 


\section{CADERNOS DAPANDEMIA $\underset{\text { SOCLIOLOGIA }}{0}$}

parte substantiva das medidas e respostas de emergência postas em prática, foram medidas que tiveram como horizonte a urgência imediata, o curto prazo: compensar, no imediato, a perda de rendimentos dos(as) trabalhadores ou flexibilizar as regras de acesso a apoio financeiro por parte de diversas entidades do sector. Vislumbra-se aqui, porém, um problema de fundo: quando as ajudas assumem a forma de apoio direto e limitado no tempo aos trabalhadores que ficaram sem rendimentos ou que os viram reduzidos, de apoio às estruturas para fazerem face às despesas extraordinárias impostas pela pandemia, ou de empréstimos com pagamento diferido, tende-se a esquecer que a retoma da 'normalidade' laboral e económica dificilmente estará para breve.

De entre os principais recursos financeiros para os incentivos ao sector do cinema e audiovisual em Portugal, existem dois, em particular, cujos dados já existentes demonstram terem sofrido uma quebra abrupta com a pandemia COVID-19: a receita publicitária em televisão (que concorre com a publicidade na internet, com melhores condições para uma recuperação mais célere); e a receita de bilheteiras, afetada pelo encerramento dos cinemas e pelas limitações que se mantiveram mesmo após a sua reabertura. Com a pandemia e o confinamento, mais consumidores ficaram rendidos aos serviços de SVOD e prevê-se que muitos deles venham a prescindir da subscrição de serviços de TV pagos (Cabrera et al., 2020). Como resultado dessa opção, as receitas para o financiamento do cinema português serão impactadas "(caso não sejam diversificadas)", assim como o volume e a heterogeneidade dos conteúdos produzidos. A própria exibição de cinema em sala, num contexto oligopolista como o português (controlado por multinacionais) pode estar em perigo, em particular as pequenas salas dedicadas à exibição de cinema independente ou de autor.

Atentando à fragilidade, que já vem do período pré-pandémico, do sector do cinema e audiovisual, é possível concluir que os diferentes segmentos desse mercado estão vulneráveis, em retração ou em profunda transformação. Este sector será, tudo o indica, impactado a longo prazo pela situação que vivemos hoje. Urge, por isso, investir em medidas estruturais que garantam a sua sustentabilidade.

\section{Outubro de 2020}

*A autora segue as normas do Acordo Ortográfico da Língua Portuguesa de 1990.

\section{Referências bibliográficas}

AA.VV. (2020). "Cinema português: onde cortar?". Público, 5 de outubro. Disponível em: https://www.publico.pt/2020/10/05/ culturaipsilon/opiniao/cinema-portugues-onde-cortar-1934033.

Banks, M. (2020). The work of culture and C-19. European Journal of Cultural Studies, 1-7.

Cabrera, B. F.J.; Cappello, M.; Chochon, L., Fontaine, G., Talavera, M. J., Valais, S. (2020). The European audiovisual industry in the time of COVID-19. Estrasburgo: European Audiovisual Observatory. Disponível em: https://rm.coe.int/ iris-plus-2020-2-the-european-audiovisual-industry-in-the-time-of-covi/16809f9a46.

Coelho, E. P. (1983). Vinte anos de cinema português (19621982). Lisboa: Ministério da Educação e Cultura.

Garcia, J. L. (coord.); Lopes, J. T.; Neves, J. S.; Gomes, R. T.; Martinho, T. D..; Borges, V. (2014). Mapear os recursos, levantamento da legislação, caracterização dos atores, comparacão internacional. Lisboa: Secretário de Estado da Cultura. Gabinete de Estratégia, Planeamento e Avaliação Culturais (GEPAC). Disponível em: http://hdl.handle.net/10451/17701.

Gorz, A. (1976). On the Class Character of Science and Scientists. In: Rose H., Rose S. (eds) The Political Economy of Science. Critical Social Studies. London: Palgrave.

Leão, Tânia L. S. S. (2019). Públicos de Festivais de Cinema em Portugal: Um Estudo Comparado. Tese de Doutoramento. Coimbra: Faculdade de Economia da Universidade de Coimbra.

Lloyd, R. (2010). Neo-Bohemia. Art and Commerce in The Postindustrial City. Nova lorque: Routledge.

Menger P.M. (2002). Retrato do Artista enquanto trabalhador. Lisboa: Roma Editora.

Neves, J. S. (2020). Cultura. In Mamede, R. P. \& Silva, P. A. (coord.), O Estado da Nação e as Políticas Públicas 2020: Valorizar as Políticas Públicas. Lisboa: IPPS/ISCTE-IUL, 25-32. Disponível em: https://ipps.iscte-iul.pt/index.php/estudos-e-publicacoes/estudos-e-publicacoes-3/784-2020-valorizar-politicas-publicas.

Kern, P. (2020). The impact of the COVID-19 pandemic on the Cultural and Creative Sector. Report for the Council of Europe. 


\section{CADERNOS}

DAPANDEMIA

$\longrightarrow$ INSTITUTO DE

Estrasburgo: Conselho da Europa. Disponível em https://keanet.eu/wp-content/uploads/Impact-of-COVID-19-pandemic-on-CCS_COE-KEA_26062020.pdf.pdf.

Silva, A. S. (2007). Como abordar as políticas culturais autárquicas? Uma hipótese de roteiro. In Sociologia, Problemas e Práticas, 54, 11-33.

\section{Agradecimentos}

Agradeço a Ana Silva, Diogo Allen, Fabienne Couvreur, Inês, Luís Apolinário, Luís Urbano, Miguel Moraes Cabral, Rodrigo Areias e a Sérgio Marques os seus testemunhos. Agradeço a Salette Ramalho e ao grupo informal PAF - Prontos a Filmar pelo auxílio prestado na preparação do texto. Agradeço, por fim, a Pedro Ferreira e a Raquel Freire pela cedência de imagens. 


\section{CADERNOS DAPANDEMIA SOCIOLOCI}

\section{A ARTE URBANA NA ENCRUZILHADA DA PANDEMIA: REFLEXÕES SOBRE O TRABALHO CULTURAL E ARTÍSTICO NUM SEGMENTO EMERGENTE}

\author{
Lígia Ferro*
}

\section{Resumo}

O texto parte de investigação prévia sobre a institucionalização da arte urbana e sua acomodação no campo da cultura e das artes, para pensar as atuais condições de trabalho dos seus protagonistas em contexto de pandemia, focalizando em particular o período do confinamento e do verão que se Ihe seguiu. Conclui-se que os artistas do campo da arte urbana estão a ser afetados de uma forma generalizada pela pandemia, enfrentando uma quebra acentuada na sua atividade. Apesar de alguma retoma durante o verão, incluindo a realização de exposições e festivais, o futuro de um setor emergente da cultura e das artes em Portugal, o qual tem dado um contributo relevante para a dinamização económica, nomeadamente ao nível local, permanece uma incógnita. Não obstante, a forte contração da atividade parece dar-nos claros indícios de que haverá efeitos indeléveis nas oportunidades, configuração e desenvolvimento do trabalho artístico neste campo.

Palavras-chave: arte urbana; pandemia; condições do trabalho artístico; campo cultural.

\section{Introdução}

A prática do graffiti começou como uma forma de expressão dos jovens dos subúrbios das cidades dos Estados Unidos e da Europa. Até ao final da década de 80, o graffiti constituía uma prática maioritariamente performada por jovens socialmente desfavorecidos dos subúrbios. É a partir do final desta década que começa a ser promovida nos meios de comunicação social e a suscitar um interesse mais alargado por parte das instituições culturais. Alguns writers foram reconhecidos no campo da arte como protagonistas de um novo movimento de vanguarda artística. Em Nova lorque, o reconhecido Andy Warhol convidou o artista de rua Jean-Michel Basquiat para expor em várias instituições consagradas da cidade. Há quem afirme que o graffiti chegou a ser uma atração turística de Nova lorque nos anos 80 (Miller 1993). De igual forma, o trabalho dos writers nova-iorquinos foi também promovido na Europa através de diversas exposições em instituições culturais reconhecidas.

À semelhança dos mecanismos descritos por Bourdieu a propósito do campo literário (1996) surgiram dinâmicas de legitimação do graffiti que levaram à valorização económica e simbólica dos seus produtos no mercado artístico. Por outro lado, devido ao caráter alternativo desta prática de rua, muitos dos seus atores insurgiram-se contra a "comercialização do graffiti", reclamando o seu cariz desviante, subversivo e de protesto social. Assim, a produção de graffiti permaneceu polarizada em duas vertentes: uma mais oculta, desviante e transgressora e outra visível, institucionalizada e legitimada.

\section{Contextualizando historicamente um novo segmento do campo cultural}

No domínio da tensão entre a vertente transgressora e institucionalizada, há que estabelecer diferenças entre os contextos europeu e norte-americano. Comparando-os, Vulbeau (1992) constatou que existem diferenças importantes relativamente à identificação territorial, mas também no que diz respeito ao processo de difusão do graffiti.

No que respeita ao contexto americano, é de sinalizar a formação de grupos mais ou menos estruturados em Nova lorque (como o UGA ${ }^{87}$ ou o $N O G A^{88}$ ) no final dos anos 70 do século $X X$. Progressivamente, alguns writers vão auferindo de um reconhecimento social que Ihes abre uma porta de passagem do "campo da delinquência»

87 United Graffiti Artists. 88 Nation of Graffiti Artists. 


\section{CADERNOS DAPANDEMIA SOCIOLOGIA}

para o «campo da cultura e da arte». Hoekstra et al (1992) documentam como, nos anos 80, o graffiti tinha um espaço próprio nas instituições culturais da cidade de Nova lorque. Assim, o graffiti nasce da rua penetrando progressivamente nas instituições culturais.

Em França, o processo foi inverso: a expansão do graffiti começa quando um certo número de writers já estão «identificados» no mundo da arte (Vulbeau 1992, 62). Antes do graffiti, foi o breakdance que conquistou um lugar no mercado da arte, particularmente com o uso dos movimentos típicos desta expressão artística pelos coreógrafos da dança contemporânea mais institucionalizada (Belhadj-Ziane 2008). No que diz respeito ao graffiti, só em 1990, Lapassade organizou uma pintura de muros na Universidade de Paris VIII, intensamente divulgada nos meios de comunicação social (Mouchtouris 2008, 96). Mas antes disso organizaram-se várias exposições que deram a conhecer a nova prática emergente dos jovens dos subúrbios norte-americanos. No contexto francês, o graffiti surge na galeria e no museu e depois espalha-se na rua.

Na Península Ibérica, a prática do graffiti desenvolve-se a partir de finais dos anos 80 e década de 90 do século XX e, consequentemente, o processo de institucionalização e comercialização da produção de graffiti é relativamente tardio. Em Lisboa, o graffiti emerge no final dos anos 80 e princípios dos anos 90 nos subúrbios, espalhando-se depois para a cidade, essencialmente para Belém, Campolide, Amoreiras, para destacar apenas as zonas mais relevantes. Desde o seu início, nos anos 90, até ao fim desta década, constrói-se a fase que os grafiteiros designam como old schoo/89. Nesta década, o graffiti era uma prática quase invisível. UBER, um dos writers do grupo THC, dedicava-se ao que chama de "graffiti de domingo à tarde», assumindo a «missão» de «legalizar» algumas paredes (Ferro, 2016).

No final dos anos 90 surgiu a primeira loja de latas de spray Montana no Bairro Alto. Até então,

89 Velha escola, usa-se o termo em inglês tal como é usada pelos writers. os meios que os grafiteiros dispunham para pintar eram muito rudimentares. Tal como em Espanha (Berti 2009), os sprays usados para pintar graffiti eram próprios para pintar metais, especialmente dedicados para automóveis e eletrodomésticos. Não existiam caps $^{90}$ específicos que permitissem dosear a tinta, nem rotuladores que possibilitassem inscrições rápidas de forma eficaz.

Com a abertura das primeiras lojas disponibilizando materiais específicos para a prática do graffiti, os writers passam a dispor de melhores condições para pintar. UBER refere que a partir do momento em que se inaugura a primeira loja de sprays, o tag ${ }^{91}$, pouco comum até então, começa a espalhar-se pela área metropolitana de Lisboa. Começa a valorizar-se muito mais o tag do que o hall of fame ${ }^{92}$. As empresas especializadas em sprays de graffiti comercializam nas suas lojas não só as latas de spray, mas também uma diversidade de produtos relacionados, como revistas, fanzines, roupa streetwear e por vezes têm pequenas galerias para exposição dos trabalhos dos writers.

A partir do momento em que o graffiti é promovido nas instituições culturais e surgem estratégias de comercialização em torno do mesmo, geram-se dois grandes grupos de writers com modos de fazer e discursos distintos. Por um lado, os que se proclamam exclusivamente como atores de rua e, por outro, os que continuam a pintar na rua, mas que também realizam trabalhos para instituições culturais e empresas, procurando remuneração pelo seu trabalho como artistas.

No virar do milénio, Calo (2003) refere que o público do graffiti era necessariamente constituído por conhecedores dos códigos do mesmo. Desde a pesquisa deste sociólogo, temos assistido a uma grande divulgação dos códigos estéticos do graffiti, incluindo nos meios de comunicação, e a utilização da "estética de rua» (Riout 1998) tem sido bem-sucedida do ponto de vista comercial.

90 Válvulas difusoras de aerossol.

91 Assinatura ou pseudónimo que identifica um escritor. Pode ser escrito na rua com marcador ou spray.

92 Parede onde, formal ou informalmente, é permitido pintar graffiti com alguma regularidade, incluindo sequências longas de peças de graffiti. 


\section{CADERNOS DAPANDEMIA SOCIOLOGIA}

De facto, participar num mercado não significa pertencer a um mesmo grupo (Simpson 2000). Surgiu um interesse tão generalizado no graffiti por parte de setores diferenciados da sociedade, fazendo com que hoje em dia seja uma estética e linguagem conhecida e apreciada por muitos.

Há alguns anos que diversas marcas de produtos de vestuário streetwear e de bebidas apoiam financeira e logisticamente eventos de graffiti em Portugal. Por vezes, são os próprios writers que procuram esse suporte, mas existem também várias iniciativas das empresas nesse sentido.

As agências publicitárias entendem que o graffiti e a arte urbana captam a atenção dos «targets mais jovens» e ajuda «a estabelecer ligações muito fortes entre marca e consumidor», segundo estudos na área do marketing e da publicidade (Mota 2009, 10). Paulatinamente, as empresas começaram a investir em campanhas de marketing baseadas na linguagem estética do graffiti devido ao facto de conceitos como "subversão», «rebeldia», «diversão», «urbano» serem associados a esta forma de cultura urbana (Mota 2009, 78). Numa estratégia de aposta na publicidade com recurso à estética de rua, existem marcas que recorrem frequentemente a artistas urbanos para personalizarem produtos e que patrocinam mesmo alguns deles de forma permanente.

Os trabalhos em campanhas publicitárias geram frequentemente divisões entre os writers. Como mencionam alguns protagonistas, a lógica do ganho económico acaba por gerar divisões entre aqueles que colocam os interesses económicos à frente do facto de pertencerem a uma comunidade urbana com uma história comum.

A popularização desta forma artística de expressão, em articulação com outros formatos, levou à formação de um novo segmento do campo cultural, com agências próprias. Desde a primeira década dos anos 2000 que o termo arte urbana começa a ser popular, construindo-se a partir da herança do graffiti. A arte urbana é assim uma "grande família composta por diferentes formatos, que passam pelo muralismo, o graffiti e a street art, incorporando igualmente elementos e propostas que provêm da arte contemporânea menos informal" (Campos e Câmara, 2020).
A arte urbana, assim como outras práticas artísticas emergentes na contemporaneidade, exprime uma contradição entre aqueles que a vivem exclusivamente na rua, de modo mais informal e espontâneo, e os que fazem dela um meio para ganhar a vida, procurando vias de profissionalização como artistas ou como agentes de promoção no campo cultural. Contudo, os dois regimes, profissional ou semiprofissional e amador, são também acumulados por alguns atores da arte urbana, à semelhança do que avançou Simões (2013) relativamente ao hip hop. Aliás a maioria dos atores que procura ganhar dinheiro fazendo arte urbana, continua a trabalhar simultaneamente na rua, valorizando a liberdade e espontaneidade que a mesma oferece. Não existem protagonistas que tenham deixado de pintar na rua porque se tornaram artistas reconhecidos.

\section{Da institucionalização à profissionalização artística: algumas notas de campo}

No trabalho de campo que realizei em Barcelona e em Lisboa de 2009 a 2011, notei que era cada vez mais consensual que se pudesse ser remunerado pelo trabalho no âmbito da arte urbana. No domínio da pesquisa, a maioria dos entrevistados sempre declarou respeitar as opções individuais pela via da profissionalização ou da execução pontual de trabalhos remunerados.

Uma parte considerável dos atores mais destacados obtêm atualmente remuneração pelo seu trabalho na arte urbana e mesmo aqueles que não executam trabalhos com contrapartidas financeiras, dizem considerar legítimo essa via de profissionalização ou semiprofissionalização. No entanto, os writers têm na sua maioria um discurso de crítica às grandes multinacionais e àqueles artistas que colaboram profissionalmente com estes grupos económicos. Se, por um lado, os atores que participam na programação das instituições artísticas e culturais são bem acolhidos de uma forma geral, aqueles que fazem campanhas publicitárias para grandes multinacionais, continuam a ser alvo de críticas. A questão não se resume ao facto de se ganhar dinheiro com a arte urbana, mas sim no modo como os writers 


\section{CADERNOS DAPANDEMIA 0 INSTITUTO DE}

o fazem. O consenso estabelece-se em torno de uma identidade do artista urbano como alguém que deve ser crítico do sistema capitalista.

Teresa Caldeira (2008) chamou a atenção para o processo de "estetização» do graffiti, que para além da legitimação do graffiti no campo da publicidade, envolve também uma promoção desta prática no campo da arte e da cultura, contribuindo para a emergência da arte urbana enquanto segmento do campo cultural. Voltando à pesquisa desenvolvida em Barcelona e Lisboa, entre 2003 e 2006, a institucionalização da arte urbana na cidade catalã era visível através da existência de variadas exposições de artistas urbanos em galerias de arte prestigiadas, da organização de eventos nos centros cívicos, nos centros culturais e museus da cidade. A partir da implementação da lei municipal para "fomentar e garantir a convivência cívica em Barcelona", a prática do graffiti foi concretamente proibida na via pública, com consequências e reflexos nas oportunidades que surgiam no campo cultural e artístico para os seus atores.

Concomitantemente, em Portugal abriram-se espaços para a arte urbana. Em Lisboa, o Departamento de Património Cultural da Câmara Municipal de Lisboa, cria a Galeria de Arte Urbana, criando mais oportunidades para os artistas urbanos participarem na agenda cultural municipal. A estratégia da Câmara Municipal de Lisboa contribuiu para a promoção da arte urbana como uma expressão artística. Em contrapartida, no início dos anos 2000, a arte urbana ainda figurava com menos frequência nas programações das instituições culturais que não eram da tutela da Câmara. Destaca-se a exposição «Para quem mora lá, o céu é lá» que o Museu Coleção Berardo organizou no Centro Cultural de Belém com obras dos grafiteiros GÊMEOS de São Paulo e que teve um grande sucesso93. Tratando-se da primeira exposição de artistas de arte urbana a ser organizada num grande Museu em Portugal. Outros espaços expositivos acolheram trabalhos do writer português VHILS, como as exposições da responsabilidade

93 A exposição decorreu entre os dias 17 de Maio e 19 de Setembro de 2010. da agência de arte Vera Cortês ${ }^{94}$ ou a que teve lugar no Museu da Eletricidade ${ }^{95}$. Até aos nossos dias, tem sido organizado todo um leque de eventos culturais de arte urbana, não só em Lisboa, mas também no Porto e em algumas cidades de pequena e média dimensão, em parte devido à criação de associações e entidades dedicadas à promoção desta forma de expressão artística.

Belhadj-Ziane (2008) refere que o grau de legitimação do graffiti e dos seus praticantes depende essencialmente do espaço em que se investe: se se tratar de um espaço acessível ao público, transgridem-se as «regras da organização social e urbana», pelo contrário se se expõe num espaço confinado ou privado, torna-se um «símbolo de modernismo artístico» (Belhadj-Ziane 2008, 24). Diversas iniciativas das instituições culturais são realizadas na rua, contudo parece que a "consagração artística» (Bourdieu 1996) se faz dentro das portas das instituições culturais. Campos (2010) referiu como poucos writers de graffiti se interessam pelas «telas exibidas em espaços fechados, não gostam do formalismo, da rigidez e do clima religioso dos museus e galerias, da adoração ao objecto» (Campos 2010, 294). Também em Paris havia writers que afirmam preferir ser uma «estrela na rua» do que um pintor medíocre no museu ${ }^{96}$ (Bischoff et al $2000,19)$. Contudo, chegados a 2020 , uma parte considerável daqueles que atuam no âmbito da arte urbana transitam com muita facilidade entre espaços interiores e exteriores, cruzando estéticas e estilos variados, trabalhando com destreza e criatividade em meios formais e informais.

Estes "novos" protagonistas do setor cultural procuraram formas de profissionalização usando os conhecimentos adquiridos nas suas práticas de rua. Os saberes da arte urbana são valorizados e rentabilizados em vários campos, à semelhança do que acontece também com os tatuadores (Ferreira 2014). A procura da via da profissionalização

94 Para mais detalhes consultar o web site da agência em http:// www.veracortes.com/

95 Exposição «Dissecção/Dissection» que esteve patente entre os dias 5 de Julho e 5 de Outubro de 2014.

96 A citação de Bischoff et al (2000) é de uma entrevista com NASTY. 


\section{CADERNOS DAPANDEMIA $\underset{\text { SOCLIOLOGIA }}{0}$}

toma frequentemente caminhos diversos. Formas comuns de rentabilização destes "saberes de rua» são o trabalho nas áreas do design, da tatuagem, da ilustração e da animação no âmbito de pequenas e médias empresas. Podemos acrescentar o estilismo e produção de vestuário vendido em pequenas lojas. Alguns artistas também se dedicam à edição de publicações específicas relacionadas com a cultura da arte urbana. Em França existem inclusivamente manuais que ensinam a pintar graffiti editados por writers (Sandevoir 2008). Paralelamente, a venda de peças de arte urbana no mercado da arte tem seguido uma tendência crescente. Desde os anos 90 que o caminho da profissionalização neste campo foi identificado em França e nos Estados Unidos (Beuscart e Grangeneuve 2003), tornando-se uma realidade na Península Ibérica neste novo milénio.

Como já foi referido, os artistas urbanos conciliam os seus trabalhos em contexto institucionais com a continuação da pintura na rua. De qualquer forma, para se ser profissional é necessário ter provas dadas na rua, quer dizer é preciso acumular capital simbólico na rua para obter o reconhecimento do seu trabalho institucional pelos pares.

A acumulação de um duplo regime que concilia um registo informal, na rua, com outro mais formal e institucional, comporta uma série de contradições. Talvez o caso mais paradigmático da contradição entre uma atitude de subversão das regras do mercado da arte e a participação nesse mesmo mercado seja o de BANKSY, artista originário de Bristol e que ficou conhecido em todo o mundo pelas suas peças de crítica social e política. No seu filme Exit through the gift shop, ele satiriza a promoção de um artista medíocre de rua no campo da arte. A obra teve uma grande projeção internacional tendo sido nomeada para os Óscares. BANKSY pintou um mural em Los Angeles com uma mensagem subversiva e irónica quando o seu filme foi nomeado. Assim, este artista move-se numa lógica de transgressão, usando os próprios espaços e agências de consagração do mercado da arte para promover o seu trabalho. Em agosto de 2015, BANKSY elevou a fasquia ao inaugurar um parque temático temporário em Inglaterra (Weston-super-Mare) que encerrou ainda em Setembro do mesmo ano, onde as contradições do sistema capitalista foram expostas através do seu trabalho e de outros artistas convidados ${ }^{97}$.

Num mundo globalizado em que a valorização da novidade é uma prioridade, a arte urbana adquiriu um espaço de destaque e reconhecimento tendo-se consagrado enquanto um importante segmento do campo cultural. A forma como os seus protagonistas lidam com este reconhecimento e oportunidades é heterogénea. No entanto, se num momento de emergência havia muitas vozes críticas relativamente à promoção dos atores do graffiti no campo da arte, atualmente parece que acumular as práticas da arte urbana na rua, informais e espontâneos, com outras formas de atuação mais institucionalizadas e comerciais, reúne um considerável consenso. Uma coisa é certa, se anteriormente o graffiti permanecia uma prática de rua, subversiva e oculta, hoje em dia vemos a arte urbana presente nos meios institucionalizados da arte, da cultura e da publicidade, formando um importante segmento cultural artístico com atores, grupos e agências próprios.

\section{A arte urbana na encruzilhada da pandemia}

Chegados a 2020, parece claro que a arte urbana constitui um segmento emergente em processo de rápida consolidação no campo cultural. Artistas como MaisMenos, VHILS, BORDALO II, MrDheo, entre outros, são hoje atores reconhecidos no campo cultural. Construíram carreiras profissionais à escala nacional e internacional, sendo responsáveis por projetos que cruzam diferentes linguagens e disciplinas artísticas. A sua formação e bagagem cultural enquanto artistas de rua e da cidade, conferiu-Ihes um papel único no campo da cultura. A par destes artistas de reconhecido prestígio artístico e cultural, muitos outros lutam pelo reconhecimento do seu trabalho, em condições mais precárias e difíceis, vivendo da livre iniciativa e autogestão financeira a partir de projetos pontuais

97 Ver https:/www.theguardian.com/artanddesign/2015/sep/ 25/banksys-dismaland-closes-weston-super-mare 


\section{CADERNOS DAPANDEMIA $\underbrace{0}_{\text {UPORTO }}$ SOCIOLOOGIA}

que vão desenvolvendo. Quais são as condições de trabalho destes artistas e como estão eles a enfrentar o contexto de crise económica que tem afetado particularmente o setor das artes e da cultura? Como enfrentaram eles o período de confinamento de 47 dias imposto pela pandemia devido à COVID-19? Quais as reflexões pertinentes que se impõem neste momento para pensar o futuro da arte urbana em Portugal?

Para respondermos a estas questões, devemos olhar de novo um pouco para trás. Se após uma fase de progressivo reconhecimento da arte urbana, foi possível sinalizar cada vez oportunidades de trabalho artístico, a verdade é que as trajetórias de trabalho destes artistas se foram construindo a partir da livre iniciativa, implicando frequentemente condições de incerteza e precariedade, como foi referido.

No meio de uma pandemia inesperada, a rua enquanto espaço primordial de trabalho e inspiração para estes artistas, ficou deserta. No confinamento devido à COVID-19, a rua foi "cancelada" e, por isso, muitos dos trabalhos de arte urbana também. MaisMenos refere como algumas pessoas se viram em situações socioeconómicas complicadas:

"Tenho amigos, e eu também passei essa fase inicial, que estiveram com grandes dificuldades, tiveram que pedir apoios à Segurança Social, aqueles apoios da treta [...] apoios de 100 ou 200 euros mensais e andaram praticamente assim até junho e depois então já começaram a arranjar alguns trabalhos."

(MaisMenos em entrevista, 2 de outubro de 2020)

MaisMenos refere que muitas iniciativas foram adiadas e canceladas, acrescentando que a arte não é uma prioridade neste momento, principalmente para o setor privado:

"Falando do meu exemplo de algumas pessoas que me são próximas (...) houve muita coisa que foi adiada, interrompida ou anulada. Eu pessoalmente tive projetos que foram cancelados, tinha a uma ida a Berlim que foi cancelada, tinha um trabalho em Lisboa para uma empresa que também foi cancelado. E são trabalhos que eu sei que não vão voltar, porque neste momento não são prioritários... Ou seja, a arte também sofre um pouco neste momento por isso. Não é propriamente uma prioridade, nomeadamente ao nível empresarial, porque se estamos em períodos de lay-off, despedimentos, etc., o lado artístico acaba por sofrer mais pois passa por uma atividade mais secundária para muitas empresas."

(MaisMenos em entrevista, 2 de outubro de 2020)

No rescaldo do confinamento, a aposta na atividade online constitui um meio para muitos artistas continuarem a trabalhar. Em maio de 2020, a imprensa portuguesa estava atenta a estas mudanças, reportando esta alternativa de trabaIho num momento considerado por alguns artistas como MisterDheo, AkaCorleone, Frederico Draw e Hazul, uma oportunidade para repensar algumas ideias que estavam no "baú" (Dias, 2020). MaisMenos refere que através das exposições online, promovidas pela Galeria Underdogs, entre outras, foi possível continuar a divulgar os seus trabalhos e a vender algumas peças:

"Foi muito estranho aquele período, porque o trabalho parou completamente. Entretanto, pessoalmente eu tive a sorte de entrar em duas exposições online, que foi uma coisa nova que apareceu. Uma delas foi com a Underdogs e acabei por fazer mais coisas com a Underdogs... [...] lançamentos de peças.... Sendo que o online, no que toca à Underdogs esteve a funcionar muito bem. Porque as pessoas como estavam em casa, queriam coisas e como não podiam ir às exposições [...] acabaram por entrar muito no espírito da coisa, ou seja, estarem muito abertos à questão do online, compraram coisas. [...] março/abril foi muito complicado, mas senti que em maio, junho e julho se retomou [a atividade], um pouco por causa disso."

(MaisMenos em entrevista, 2 de outubro de 2020) 
CADERNOS

DAPANDEMIA

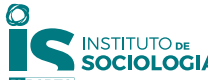

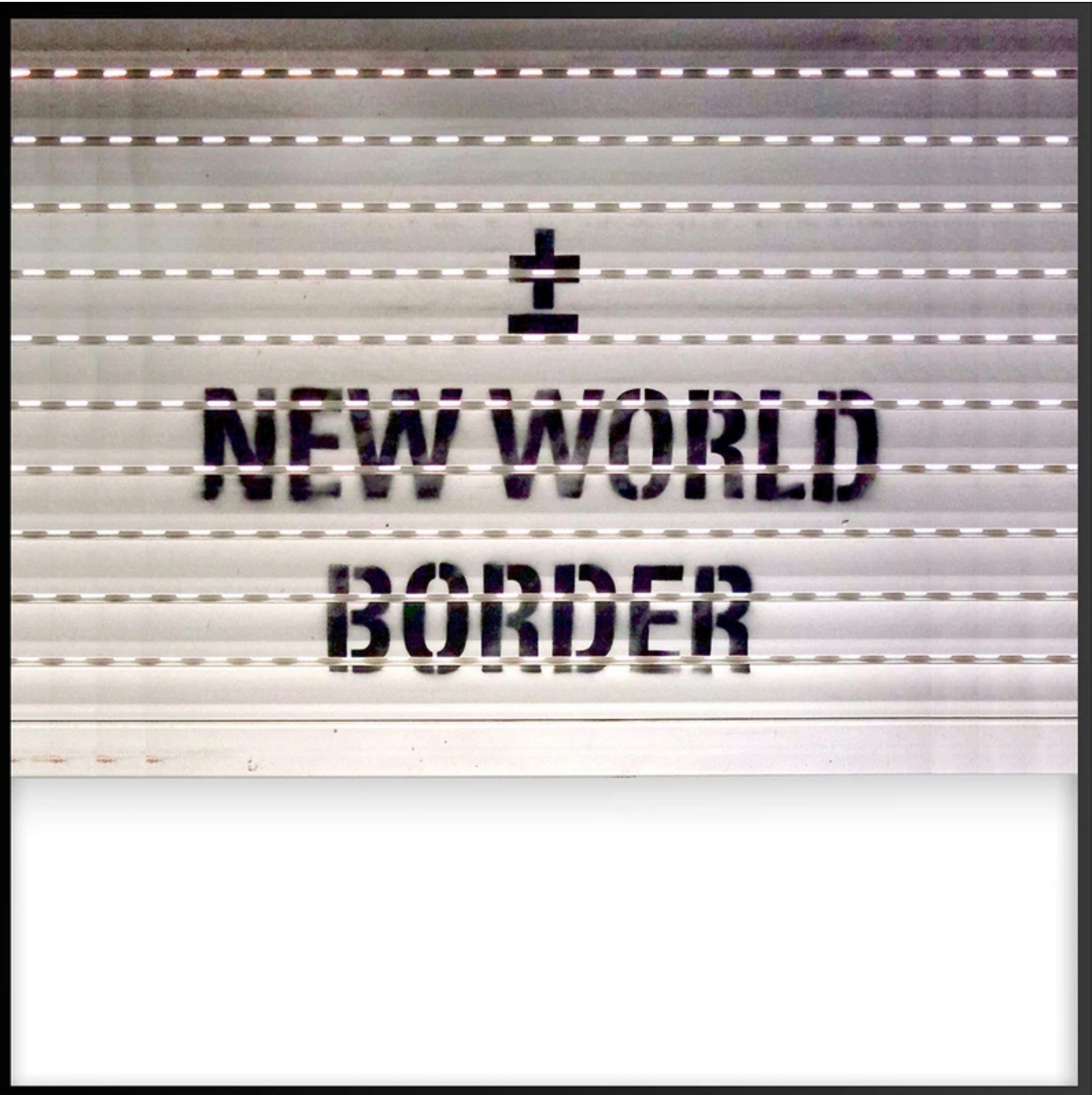

Figura 1 - "New World Border", peça de MaisMenos vendida no âmbito da exposição online "Right Now", organizada pela Galeria Underdogs. · (Miguel Januário (c) 2020) 


\section{CADERNOS DAPANDEMIA $\underbrace{\text { SNSTITUTODE }}_{\text {OUPORTO }}$ SOCIOLOGIA}

Quando analisa a estratégia política de apoio aos artistas do setor cultural, o artista considera que a mesma foi manifestamente insuficiente, tendo deixado vários profissionais das artes e da cultura em situação de necessidade. Segundo MaisMenos, - Ministério da Cultura, revelando algum desconhecimento da realidade vivida, mostrou distanciamento face às necessidades imediatas que se sentiram no domínio das artes e da cultura:

"A estratégia foi péssima. Os atrasos, os apoios quase de gozo, porque ninguém vive com 100 euros, ou seja a forma como calcularam os apoios foi ridícula, as pessoas tiveram mesmo de se virar... Há gente que passou fome, há gente que teve de ir para casa de amigos, há gente que perdeu casa, há gente que teve de pedir ajuda, e conheço gente de várias áreas [da cultura e das artes] que não tinha por onde se virar, que se aguentou um mês mas não aguentou dois... [...] E depois tivemos toda uma atitude elitista e de distanciamento, mais um distanciamento, por parte do Ministério da Cultura."

(MaisMenos em entrevista, 2 de outubro de 2020)

A seguir ao confinamento houve um lento retomar das atividades, em particular dos festivais de arte urbana que decorreram em diferentes localidades, sofrendo algumas alterações no que diz respeito à sua configuração. No caso do Festival Iminente, apostou na organização de oficinas, numa lógica de aproximação à comunidade e na linha do que se tem feito em iniciativas de educação artística informal:

"Os festivais também voltaram. Tenho conhecimento de algum pessoal que voltou a ir a festivais, a Vila Real, Estarreja... Coisas organizadas pela Mistaker... Eu vi que o MAR foi, falei com ele, e estava a ter trabalho, uma ou outra encomenda de colecionadores. Portanto a coisa parou inicialmente, mas depois lentamente começou a arrancar outra vez. Eu tive a sorte de ser convidado a ir ao Festival Iminente, agora em setembro.... Foi porreiro [...] fui dar duas oficinas
[...] me garantiu ali mais algum dinheiro e a coisa aconteceu apesar de ser uma coisa especial. Isto tem um lado positivo que é trouxe novas formas de pensar, ou seja, o online era uma coisa que não existia e existiu e correu muito bem. A aposta no online, ou seja de fazer lançamentos online também foi algo que parece mais promissor agora e a questão das oficinas no Iminente: o Iminente não fazia oficinas, arranjou uma forma de se realizar ainda este ano [...] que foi criar oficinas, workshops, ora em bairros ora no Panorâmico [de Monsanto], com inscrições. Teve algum sucesso, correu bastante bem e foi muito interessante, o que deu novas perspetivas também ao próprio Festival Iminente para os próximos anos, e se calhar alargar-se mais a esta questão da proximidade com as pessoas [...] e a inteirarem-se mais com a arte urbana."

(MaisMenos em entrevista, 2 de outubro de 2020)

O artista mencionou como o espírito coletivo de entreajuda se intensificou nos momentos difíceis que se viveram e vivem. A solidariedade entre os artistas e os agentes culturais da arte urbana tem sido o motor deste campo de atividade:

"Nesta altura, eu partilho atelier com alguns artistas e alguns deles de arte urbana e que criaram entre eles, entre artistas, núcleos muito fortes e que conseguem criar laços de entreajuda, ou seja, trabalhos, exposições, encomendas em que eles próprios acabam por se entrelaçar e ajudar. [...] Acho que há um reforço disso. E está tudo a tentar puxar para a frente. Está tudo a tentar retomar a atividade. Quem tem uma galeria com um espaço expositivo dedicado à arte urbana, está a tentar continuar com a sua atividade, ou seja, está a puxar pelos artistas e os artistas estão a puxar para a venda, por isso também puxam por esses espaços e há aqui uma entreajuda muito interessante. [...] Há aqui uma tentativa de retomar os trilhos."

(MaisMenos em entrevista, 2 de outubro de 2020) 


\section{CADERNOS DAPANDEMIA $\underbrace{0}_{\text {UPORTO }}$ SOCIOLOOGIA}

Salientando que ainda permanece uma grande incerteza relativamente à evolução do campo da arte urbana neste momento, o artista entrevistado afirmou que os artistas mais consagrados terão melhores recursos para enfrentar a crise. Afirma ainda que inevitavelmente vamos assistir a um retrocesso neste domínio, no sentido em que as oportunidades para os novos artistas vão necessariamente diminuir devido à contração do setor da cultura e das artes:

"Sinceramente acho que [o campo da arte urbana] vai retroceder uns anos no sentido em que, artistas que de alguma forma estejam institucionalizados e que já tenham carreira, atelier de artista, estúdio de artista já de alguma forma garantidos, acho que a coisa vai continuar. Porque estamos a falar de percursos muito grandes, de relações muito dinâmicas com capacidade financeira e com colecionadores, rede de contactos... Ou seja, as coleções vão continuar, as galerias vão continuar, os festivais vão continuar, portanto esses artistas vão continuar a ter trabalho. Em geral, os artistas vão continuar a ter trabalho na arte urbana. Até acho que a arte urbana pode ser das artes que menos venha a sofrer em relação, por exemplo, à música ou ao teatro, por exemplo. [...] Acho que as coisas vão estar mais difíceis para quem de alguma forma vivia de forma mais precária com a arte urbana e que já tinha que fazer outros trabalhos, acho que vai ter de garantir isso mais. Para quem não tinha uma galeria ou não tinha um estúdio que funcione já quase em termos empresariais [...] vai ter mais dificuldades. [...] Ou seja vai haver um retroceder... Se havia procura, havia exposições a acontecer, agora vai haver menos. [...] Para quem tem muito, um pouco menos não é assim tanto, para quem tem pouco, um pouco menos é muito. [...] Ainda é difícil perceber de que forma é que a arte urbana se vai reconfigurar."

(MaisMenos em entrevista, 2 de outubro de 2020)
O confronto com a rua vazia, a rua em que muitos escondem a face e se desviam do outro, a rua regulamentada na qual temos os nossos passos criteriosamente orientados e planeados, continua a ser um exercício inspirador para os artistas urbanos (Dinis, 2020). Alguns tomaram esta oportunidade para intervir na rua. MaisMenos optou por não pintar fora de casa durante o confinamento, apesar de ser "uma altura excelente para pintar", pois considera que tal "não teria um impacto positivo". O artista sublinha a realidade anti-situacionista que vivemos na rua das nossas cidades, constituindo um cenário novo de inspiração:

"A rua continua a ser um palco de inspiração, então com tudo isto que está a acontecer, a rua tornou-se num novo cenário. [...] Já viste o quanto isto se tornou anti-situacionista? Obrigam-te a andar pela direita, com setas no chão, "entre por aqui e saia por aqui" [...] Tu já não andas na deriva. [...] Tudo isto é inspirador no sentido em que questionas o que se está passar."

(MaisMenos em entrevista, 2 de outubro de 2020)

A reflexão sobre a pandemia e as suas implicações sociais, culturais e económicas encontra-se plasmada na arte urbana. Muitas são as peças que refletem as contradições e dificuldades do período pandémico. Em junho de 2020, em pleno "desconfinamento", VHILS pintou um mural no Hospital de São no Porto, em homenagem aos profissionais de saúde (Costa, 2020) e outros trabalhos de arte urbana têm sido realizados numa rua diferente e desafiante. As dificuldades destes artistas mantêm-se agora num período em que vivemos uma segunda vaga de infeções que coloca graves problemas à nossa sociedade e economia. Os protagonistas do campo cultural encontram diversos problemas à sua atividade profissional desde a primeira vaga de infeções. O acumular de carências várias e a degradação das condições de trabalho e de vida destas pessoas num inverno longo e difícil como o que temos pela frente, poderá deixar marcas indeléveis na cultura em Portugal. 


\section{CADERNOS DAPANDEMIA

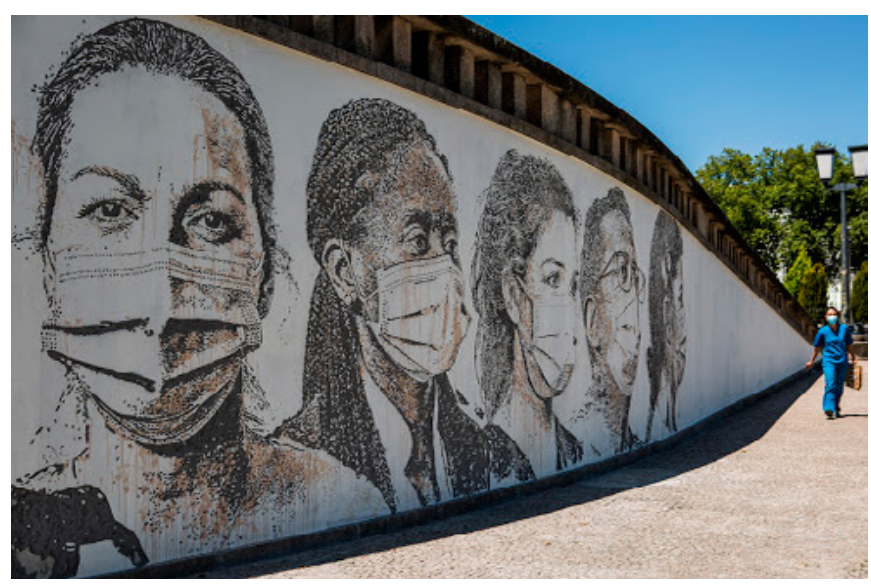

Figura 2 - Mural de homenagem aos profissionais de saúde da autoria de VHILS, Hospital de São João, Porto.

(Filipa Brito ๑) 2020 .

\section{Reflexões finais}

A arte urbana contribuiu para a geração de um determinado «capital cultural» das cidades (Zukin 1998) e sabemos como a oferta cultural se configura como um dos principais atrativos das «cidades mundiais» (Hannerz 1996). O novo consumo urbano veio intensificar a competição entre «capitais culturais pelos dólares dos turistas, as boutiques e as empresas caras, os eventos individuais e dos media que têm um efeito na inovação cultural» (Zukin 1998, 826).

Depois de um momento em que o graffiti constituiu a cultura de base para a formação do campo da arte urbana, atravessado por fortes processos de institucionalização e comercialização, tornou-se evidente a existência de trajetórias profissionalizadas neste setor, apesar de estarmos a falar de trajetórias com diferentes graus de profissionalização. Sabemos que uma parte considerável destes artistas trabalha em regime semiprofissional, acumulando a atividade artística com outras atividades profissionais, para poder enfrentar o seu orçamento mensal. De resto, esta tendência tem-se vindo a verificar nos domínios mais precários do campo cultural e artístico, afetando particularmente os artistas imigrantes em Portugal, provenientes de países de fora da EU (Ferro et al, 2016).
Em tempos de pandemia devido à COVID-19, estes artistas encontraram-se em situações complexas de vida, ficando sem qualquer meio de subsistência e vivendo com alguns parcos apoios da Segurança Social. O espírito coletivo de solidariedade saiu reforçado desta crise, ao mesmo tempo que alguns eventos importantes neste setor apostaram mais em iniciativas focalizadas no estímulo de laços com a comunidade, dando protagonismo aos artistas urbanos neste âmbito (caso do Festival Iminente). Por outro lado, parece evidente que os artistas mais consagrados terão mais recursos para enfrentar esta crise pandémica, ao contrário dos artistas semiprofissionalizados, para quem este momento pode significar o fim de um percurso. Certamente a perda de atividade no domínio da arte urbana terá impactos consideráveis nas condições de trabalho e de vida destes artistas, mas também influenciará de forma negativa a economia, nomeadamente as economias locais, para as quais este segmento emergente se tornou tão importante. É essencial pensar políticas públicas capazes de garantir condições mínimas de trabalho e de vida para estes artistas. Urge pensar as artes e a cultura em tempos de pandemia, olhando não só para o seu valor económico, mas também para o seu valor societal.

\section{Outubro de 2020}

*A autora segue as normas do Acordo Ortográfico da Língua Portuguesa de 1990.

\section{Referências bibliográficas}

Belhadj-Ziane, K. (2008). Dynamique historique d'une contraculture: la culture hip hop. In Actualité Graffiti, Actes de Co/loque Université de Perpignan - Via Domitia - Avril 2007, Perpignan: Presses Universitaires de Perpignan, 6-33.

Berti, G. (2009). Pioneros del Graffiti en España. Valencia: Universitat Politècnica de València.

Beuscart, J.S., \& Grangeneuve, L. L. (2003). Comprendre le graffiti à New York et à Ivry (Note liminaire aux textes de Richard Lachmann et de Frédéric Vagneron). Terrains \& Travaux. Cahiers du département de sciences sociales de l'ENS de Cachan, n. ${ }^{\circ 5}$, «Urbanité(s). Sociabilités et cultures urbaines», 47-54.

Bourdieu, P. (1996). As regras da arte. Génese e estrutura do campo literário. Lisboa: Editorial Presença. 


\section{CADERNOS}

DAPANDEMIA

Caldeira, T. (2008). Desigualdade e segregação espacial como algo desejável e/ou inevitável - novas configurações, conferência inaugural do VI Congresso Português de Sociologia, Lisboa, Reitoria da Universidade Nova de Lisboa, 25 de junho de 2008.

Calo, F. (2003). Le Monde du Graff. Paris: L'Harmattan.

Campos, R. (2010). Porque Pintamos a Cidade? Uma Abordagem Etnográfica do Graffiti Urbano. Lisboa: Fim De Século.

Campos, R. \& Câmara, S. (2020). Arte(s) Urbana(s). Famalicão: Húmus.

Costa, I. P. (2020). Eis o mural de Vhils no Hospital de São João. Porque "os profissionais de saúde também precisam de ser cuidados", Público, 19 de junho de 2020, consultado no dia 30 de setembro de 2020 em URL: https:// www.publico.pt/2020/06/19/p3/noticia/eis-mural-vhils-hospital-sao-joao-profissionais-saude-tambem-precisam-cuidados-1921173

Dias, D. (2020). Entre o atelier e as exposições virtuais: os novos murais da street art, Público, 17 de maio de 2020 (consulta a 2 de outubro de 2020 em URL: https://www. publico.pt/2020/05/17/culturaipsilon/noticia/atelier-exposicoes-virtuais-novos-murais-street-art-1916561)

Ferreira, V. S. (2014). Entre as Belas-Artes e as artes de tatuar: novos itinerários de inserção profissional de jovens tatuadores em Portugal, Antropolítica: Revista Contemporânea de Antropologia, no 37, 79-106.

Ferro, L. (2016). Da rua para o mundo: etnografia urbana comparada do graffiti e do parkour, Lisboa: Imprensa de Ciências Sociais.

Ferro, L.; Raposo, O.; Cordeiro, G.; Lopes, J. T.; Veloso, L; Nico, M.; Abrantes, M.; Abrantes, P.; Varela, P.; Bento, R.; Caeiro, T. (2016). O trabalho da arte e a arte do trabalho: circuitos criativos de artistas imigrantes em Portugal, Lisboa, Observatório das Migrações (http://www.om.acm.gov.pt/documents/58428/177157/Estudo_OM58_br.pdf/521e91d4-f875-49cd-ba7a-36a6894c8618).

Hannerz, U. (1996). Transnational connections. London: Routledge.

Hoekstra, F. et al. (1992). Coming from the subway. Histoire et Développement d'un mouvement controversé. Paris: VBI.

Miller, I. (1993). Guerrilla artists of New York City, Race \& Class, no $35-1,27-40$.

Mota, Â.. (2009). Marcas e arte urbana. Apropriação de street art em estratégias de marketing, Tese de Mestrado em Gestão de Mercados de Arte, Lisboa, ISCTE - Business School, Instituto Universitário de Lisboa.

Mouchtouris, A. (2008). Graffiti esthétisme populaire. In Actualité Graffiti, Actes de Colloque Université de Perpignan - Via Domitia. Perpignan: Presses Universitaires de Perpignan, 79-103.

Riout, D. (1998). Le graffiti, la rue et le musée. In L'Esthétique de la rue. Colloque d'Amiens, orgs. Françoise Coblence, Sylvie Couderc e Boris Eizykman. Paris: L'Harmattan, 191-204.

Sandevoir, F. (2008). Y'a écrit KWA? Le graffiti expliqué aux curieux et aux débutants. Athènes: Éditions Alternatives.
Simões, J. A. (2006). Entre o "real" e o "virtual": representações e práticas culturais juvenis fora e dentro da Internet. O caso do hip-hop português, Tese de doutoramento, Lisboa, Faculdade de Ciências Sociais e Humanas - Universidade Nova de Lisboa.

Simpson, T. A. (2000). Streets, sidewalks, stores and stories: Narrative and uses of urban space, Journal of Contemporary Ethnography, n.-29: 682-716.

Vulbeau, A. (1992). Du tag au tag. Paris: Desclée de Brower.

Zukin, S. (1998). Urban lifestyles: Diversity and standardization in spaces of consumption, Urban Studies, vol.35, n.ำ 5, 825-839.

\section{Agradecimentos}

Agradeço a MaisMenos pela generosidade em conceder a entrevista que aqui se integra parcialmente e analisa. 


\section{CADERNOS DAPANDEMIA SOCIOLOCI}

\section{“RECEBO VERDI". A CULTURA DOS RECIBOS VERDES NA CULTURA}

\author{
José Soeiro*
}

\section{Resumo}

Em março de 2020, a suspensão das atividades públicas na Fundação de Serralves e na Fundação Casa da Música dá início a um conflito laboral entre estas instituições e um conjunto de trabalhadores a "recibo verde". Tomando estes dois exemplos como estudos de caso, procura-se refletir sobre o processo de precarização no setor da cultura, dos espetáculos e do audiovisual e sobre as características das mobilizações nesta área em torno do reconhecimento das relações laborais.

Palavras-chave: relações laborais; "falsos recibos verdes”; precarização; ação coletiva.

É porventura um lugar comum falar-se da precariedade como um verdadeiro "novo normal" no mundo do trabalho, violentamente exposto com a crise pandémica. E, no entanto, a tendência está identificada e não vem de agora. As relações precárias de trabalho, sem proteção social ou vínculo, não são um fenómeno novo nem marginal na história do capitalismo. Mesmo nos períodos de maior regulação das relações laborais, vastos sectores, como as mulheres ou os migrantes, foram remetidos para o trabalho informal, para o trabaIho clandestino ou para o trabalho reprodutivo não reconhecido nem remunerado, mantendo-se à margem do contrato de trabalho e dos direitos que Ihe eram associados. A precariedade de hoje acontece, contudo, depois de um processo amplo de institucionalização das relações de trabalho e corresponde, por isso, à desarticulação das formas de regulação legal, de solidariedade e de proteção social que haviam sido construídas e inscritas no Estado. Atualmente, em Portugal, a soma dos trabalhadores desempregados e dos trabaIhadores precários constitui a maioria da classe trabalhadora. ${ }^{98}$ No setor da cultura, dos espetáculos e do audiovisual, essa maioria parece ser esmagadora. Mas se a precariedade e os "falsos recibos verdes" são um instrumento de dominação, essa condição precária tem sido também um fermento de lutas importantes, nomeadamente no campo cultural. As recentes mobilizações protagonizadas pelos precários de Serralves e da Casa da Música são dos exemplos mais expressivos da luta pelo reconhecimento de direitos laborais em tempos de pandemia.

\section{"O espetáculo da precariedade"}

No Portugal do pós-25 de abril, o reconhecimento legal da precariedade começou com a lei dos contratos a prazo (ainda na última metade da década de 1970), que se instalaram como uma característica estrutural das relações de trabalho, atingindo, nas últimas duas décadas, quase $20 \%$ dos trabalhadores por conta de outrem (a proporção era de 19\% em 2010 e de 17,6\% em 2019). A partir da década de 1980, a precarização prossegue também através de uma nova via, com um enquadramento progressivamente numeroso de trabalhadores na categoria de "independentes": neste caso, o contrato de trabalho dá lugar ao "recibo verde", transformando-se o empregador num "cliente" e o trabalhador num alegado "prestador de serviços". Na década de 1990, começa

98 Portugal é um dos países europeus que apresenta uma maior incidência da contratação não permanente de trabaIhadores: cerca de $22 \%$ do total dos trabalhadores por conta de outrem (OIT, 2018: 33-35). Se considerarmos apenas o setor privado, a incidência da precariedade contratual ronda os $36,4 \%$. A este peso dos contratos precários haveria que somar "falsos recibos verdes" (que são uma parte não estimada dos cerca de 500 mil registados como trabalhadores independentes) e ainda todo o universo da informalidade. A tendência de precarização pode aliás ser verificada neste dado: "entre 2013 e 2018, 76\% do emprego líquido criado no setor privado baseou-se em contratações precárias" (Caldas, Silva e Cantante, 2020: 99). Para obtermos a conta dos "desemprecários" (Soeiro, 2015), teríamos de somar ao contingente de precários o universo dos trabalhadores desempregados - uma parte significativa dos quais sem acesso ao subsídio de desemprego (vd. Pedroso, 2020). 


\section{CADERNOS DAPANDEMIA SOCIOLOGIA}

a ganhar terreno a intermediação laboral através das "empresas de trabalho temporário", crescentemente legitimadas pela lei. Nos últimos vinte anos, a estas três figuras típicas do precariado o trabalhador a prazo, o falso recibo verde, o trabalhador temporário -foram-se somando outras. Por exemplo, a do desempregado assistido (a trabalhar por via de "programas ocupacionais" ou de "contratos emprego inserção", aos quais não corresponde um salário), a do bolseiro (nomeadamente na investigação científica), a do trabalhador "externo" (subcontratado através de empresas de "outsourcing") ou, mais recentemente, a do trabalhador uberizado (uma espécie particular de emprecário das plataformas, isto é, de trabalhador precário formalmente enquadrado como "empresário"). Neste processo, não apenas se degradaram condições de trabalho e formas de representação coletiva, como se operou uma mudança essencial no regime de regulação: uma verdadeira "deslaboralização" de centenas de milhares de relações de trabalho que, como que num passe de mágica, deixaram de ser enquadradas pelo direito laboral e passaram a sê-lo pelo direito dos negócios. ${ }^{99}$

No setor da cultura, estes processos ocorreram com grande intensidade. A precarização do trabaIho nesta área não estará desligada, entre muitos outros fatores, da escassez orçamental crónica, da instalação da cultura do "projeto" nos financiamentos e na organização do trabalho criativo, da fragilidade das estruturas artísticas, da debilidade da ação e representação sindicais e de uma rede de infraestruturas públicas que - nomeadamente no campo das artes de palco - está muito aquém, quando comparada com outras áreas do serviço público, como a educação ou a saúde. A pouco e pouco, os "recibos verdes" tornaram-se comuns no setor, ao ponto de terem sido naturalizados como a forma "adequada" e "possível" de enquadrar relações de trabalho marcadas, por exemplo, pela ausência de exclusividade, pela pluralidade

$99 \mathrm{Um}$ dos autores que mais sagazmente intuiu este processo de "deslaboralização" e que mais insistiu na sua centralidade de entre as múltiplas técnicas jurídicas de precarização do trabalho atualmente disponíveis foi o professor Jorge Leite (2013). de empregadores, pela descontinuidade e intermitência de funções ou pela autonomia. Mas alastraram-se também a funções "permanentes", com um só empregador e todas as características do trabalho dependente.

Em Portugal existiam, de acordo com os últimos dados disponíveis do Inquérito ao Emprego (INE, 2020), mais de meio milhão (551,5 mil, para sermos exatos) de "trabalhadores por conta própria como isolados", isto é, trabalhadores inscritos como "independentes", sem outros a seu cargo. Desses, de acordo com a Autoridade Tributária, 315 mil eram exclusivamente "trabalhadores a recibo verde", isto é, não acumulavam rendimentos de trabalho independente com outros provenientes de trabalho subordinado. Nestes cerca de trezentos mil enquadram-se, sem sombra de dúvida, uma parte significativa dos 131,4 mil trabaIhadores da área cultural e criativa contabilizados pelo INE.

Esta generalização da "cultura dos recibos verdes" no setor da cultura tem dado origem a uma tripla precariedade. Para muitos (embora haja a este nível diferenças significativas), é desde logo uma precariedade de rendimento, com vencimentos baixos e uma responsabilização desequilibrada em termos das contribuições para a Segurança Social, que ficam quase exclusivamente do lado do trabalhador. Em segundo lugar, trata-se de uma precariedade de proteção social, que corresponde no fundo a uma dupla desproteção: a que resulta da ausência de um contrato de trabalho, de segurança no emprego e de proteção contra o despedimento; e a que decorre de um regime de segurança social com uma cobertura muito menor do que a que se aplica aos trabalhadores por conta de outrem, o que aliás obrigou, no período da pandemia, à criação de mais do que um "apoio extraordinário" para os trabalhadores independentes, que se confrontaram com 


\section{CADERNOS DAPANDEMIA $\underset{\text { SOCIOLOGIA }}{0}$}

as lacunas profundas das prestações sociais existentes. ${ }^{100} \mathrm{Em}$ terceiro lugar, trata-se de uma precariedade de representação coletiva, na medida em que o enquadramento através da figura do "recibo verde" atira as pessoas para fora do perímetro formal das suas instituições (sendo tratados como trabalhadores externos ou prestadores de serviços ocasionais) e dos mecanismos existentes de associação, como as Comissões de Trabalhadores, por exemplo. Esta tripla precariedade ficou particularmente exposta durante a crise pandémica. Os casos de que trata este texto - o da Casa da Música e o da Fundação de Serralves - parecem-nos ser, a este propósito, exemplares.

\section{"Será que somos mesmo intermitentes? Será que somos trabalhadores independentes?”.}

Em meados de março, quando o Governo tomou a decisão de suspender as atividades letivas presenciais nas escolas e de reduzir ao imprescindível o atendimento presencial nos serviços públicos, a Casa da Música (a 12 de março) e a Fundação de Serralves (a 13 desse mês) decidiram suspender as suas atividades públicas e comunicaram aos trabalhadores, nomeadamente aos que se encontravam enquadrados com recibos verdes, o encerramento ao público, o cancelamento das atividades previstas e dos trabalhos agendados.

No caso de Serralves, um grupo de trabalhadores do Serviço Educativo-Artes da Fundação entregou, a 17 de março, uma proposta escrita à Coordenação no sentido de serem encontradas alternativas, designadamente com atividades online. $\mathrm{Na}$ Casa da Música, a comunicação entre a Direção e os trabalhadores a recibo verde (nomeadamente técnicos de som e de palco, assistentes de sala, músicos-formadores do serviço educativo e guias) deu início, nas semanas seguintes, a um debate e a uma

100 Foi o caso do Apoio Extraordinário à Redução da Atividade Económica, ao qual apresentaram requerimento cerca de 200 mil trabalhadores independentes e que abrangeu mais de 160 mil, entre os meses de março e outubro (GEP, 2020) e do Apoio a Situações de Desproteção Social de Trabalhadores Independentes. incerteza sobre a política de pagamentos: a alguns precários foi proposta uma bolsa de horas, entendida como uma "espécie de mesada fixa baseada no rendimento médio dos últimos seis meses", que depois seria deduzida, como um empréstimo, nos rendimentos a auferir em trabalhos futuros, ao longo de três anos, situação que contrastava com o que estava a ser proposto aos trabalhadores com vínculo e aos artistas cancelados; a outros trabalhadores a recibo verde, como os assistentes de sala e os guias, foi proposto apenas que procurassem apoio junto da Segurança Social.

Os dois casos tornaram-se públicos em abril. Através de uma "Carta Aberta a Isabel Pires de Lima" (uma dos dois membros nomeados pelo Estado para o Conselho de Administração da Fundação de Serralves), datada de 5 de abril, os arte-educadores da Fundação tomam posição, propondo que seja assumida pela instituição uma responsabilidade para com eles, nomeadamente através de uma compensação pelas atividades canceladas ou por via de alternativas que passassem, nomeadamente, pela continuação das atividades através de teletrabalho. Na Casa da Música, é enviado à direção, a 18 de abril, um abaixo-assinado subscrito por 28 trabalhadores com contrato e por 64 "prestadores de serviço", no qual se manifesta preocupação pela "forma como estão a ser tratados os numerosos profissionais independentes que trabalham na Casa da Música" e se acusa a Administração de "falta de responsabilidade social", classificando-se as soluções propostas aos trabalhadores a recibo verde como "indignas". Esse mesmo abaixo-assinado seria enviado para a Ministra da Cultura a 23 de abril e tornado público a 28 , através da imprensa.

O que se segue a estas duas tomadas de posição públicas é um intenso processo de conflito entre os trabalhadores precários das duas instituições e as respetivas Administrações, com uma assinalável repercussão mediática e política. Antes de voltarmos a este ponto, vale a pena transcrever uma seleção de alguns dos testemunhos dos trabalhadores, que dão um retrato vivo, na primeira pessoa, da sua própria condição, das suas trajetórias laborais, bem como das relações estabelecidas com as respetivas instituições. 


\section{CADERNOS DAPANDEMIA SOCIOLOGIA}

Sou educadora do serviço educativo de Serralves desde 2010, tendo a minha colaboração com este departamento começado em 2008. Em 10 anos de trabalho, mais de $97 \%$ dos meus rendimentos são provenientes da Fundação de Serralves a quem dei 7 dias de disponibilidade semanal durante quase a totalidade deste período. Nunca tive direito a férias pagas, subsídios ou prémios. Não fiz uso da licença de maternidade e regressei progressivamente ao trabalho 2 meses depois do meu filho nascer. Sempre trabalhei aos fins de semana e grande parte dos períodos de férias escolares. Sempre concebi um sem-fim de atividades para O SE estruturar o seu programa e nunca fui paga por isso. Já representei o SE no estrangeiro algumas vezes, sendo que numa em particular o fiz em substituição da sua coordenação. Fui designada educadora sénior sendo-me atribuídas pontualmente funções de orientação e avaliação de educadores juniores. Há um ano atrás fui convidada para conceber e orientar um projeto de Serralves em parceria com a Câmara Municipal do Porto, cuja duração seria de 2 anos. Nesse sentido, vi-me obrigada a recusar cerca de 30\% do horário que me foi proposto pela escola onde atualmente leciono. O referido projeto nunca aconteceu. Não me foi paga a conceção do mesmo e nunca me foi dado nenhum esclarecimento oficial acerca do assunto. Eu não sou independente. Eu sou parte da equipa do serviço educativo artes da Fundação de Serralves.

Raquel Sambade, testemunho publicado num documento distribuído pelos trabalhadores, julho de 2020

Trabalho com a equipa do Serviço Educativo da Fundação de Serralves desde novembro de 1992, sempre a recibos verdes. Inicialmente a tempo inteiro e depois a tempo parcial (desde 1998-99), com 3 dias e meio de disponibilidade, ou mais, dependendo dos anos. Essa disponibilidade de tempo não é paga! Apenas nos primeiros anos (até 1998-99), existia uma mensalidade simbólica para preparação das visitas às exposições e reuniões, depois disso, contando neste momento com 51 anos de idade, continuo como tarefeira, paga apenas pelo tempo de contacto direto com o público e reuniões, havendo muito trabalho e disponibilidade não remunerado. Até os catálogos das exposições, que sempre nos foi dito que eram uma forma de compensação e pagamento, nos foram retirados - o próprio material de trabalho e pesquisa interna?! A minha formação, em várias áreas do conhecimento, do saber ao fazer e ao ser, é uma mais-valia para a instituição, que recorre dela quando bem precisa (visitas orientadas, oficinas, preparação e elaboração de documentos, formação dos colegas...). No entanto, o contributo de Serralves para a minha formação é praticamente nulo, mas a exigência no domínio desses saberes é cada vez maior, sem o seu reconhecimento respetivo, especialmente financeiro! A experiência acumulada também não interessa a esta instituição - nunca fui contactada para uma única atividade desde que a pandemia da COVID-19 obrigou ao encerramento do museu e das suas atividades, mesmo depois da sua reabertura a partir de 18 de maio. Ao fim de quase 28 anos ao serviço da Fundação de Serralves, com pelo menos $50 \%$ do meu tempo semanal afeto ao Serviço Educativo desta instituição, não recebi uma única comunicação pessoal, explicação ou preocupação por parte dos seus representantes hierárquicos, o que é bastante revelador do desprezo para com os seus colaboradores - somos nós que damos a cara, a emoção e o conhecimento, perante o público que nos visita diariamente!

Rita Martins, testemunho na audição pública na Assembleia da República, 23 de setembro de 2020

Trabalhamos em todas as exposições, no Museu, na Casa de Serralves, na Casa Manoel de Oliveira, e até em exposições itinerantes fora de Serralves. Estamos subordinados a uma chefia, temos um horário das 9 h30 às $17 \mathrm{~h} 30$ controlado por um cartão de funcionário, conduzimos 


\section{CADERNOS DAPANDEMIA $\underbrace{\text { SNSTITUTODE }}_{\text {OUPORTO }}$ SOCIOLOGIA}

carros de Serralves, temos funções de representação da instituição, mas nunca nos foi proposto nenhum tipo de contrato.

Ricardo Costa Dias, testemunho na sessão pública na Assembleia da República, 23 de setembro de 2020

O meu nome é Sara e trabalho como assistente de sala na Casa da Música desde 2009. Não sei se ainda sou assistente de sala da Casa da Música. Neste momento posso já não ser. Já não sei também o que é, hoje, a Casa da Música. Mas sei que não está a ser o sonho que lhe deu origem, uma casa para todas as músicas e para todas as pessoas, voltada para a comunidade. (...)

O apoio do Estado já está lá, chega todos os anos, e são quase 10 milhões de euros por ano. Será que somos mesmo intermitentes? Será que somos trabalhadores independentes? Não somos. Na Casa da Música, além dos trabalhadores efetivos, há dezenas e dezenas de trabaIhadores com vínculo precário, a recibo verde, que deveriam estar integrados nos quadros. A $100 \%$, a $50 \%$, a $25 \%$, fosse o que fosse. Mas nunca em regime de trabalho independente: temos a obrigação de trabalhar no local que pertence ao empregador; usamos equipamentos que pertencem ao empregador; usamos farda que pertence ao empregador; temos horários de trabalho impostos; se recusamos trabalho, é-nos cobrada fidelidade; chega a haver quem seja repreendido por exercer a mesma atividade independente noutro local. Somos falsos recibos verdes, não haja dúvidas. (...)

A administração e a direção da Casa da Música fecharam-se em si mesmas e não perceberam que há momentos da história em que já não é possível calar. Quando mais de 90 trabalhadores denunciaram o que consideravam injusto, já não estavam dispostos a calar e deixaram isso escrito. Será que estamos assim tão longe do horizonte daqueles olhares, que nos tornámos invisíveis? Será que é mais confortável gerir números do que ver as caras e ouvir as vozes desses números, correndo o risco de ser assaltado por uma nesga de sentido ético? (...)

É preciso recusar uma gestão puramente empresarial e antiética, antidemocrática e até persecutória, como a que ficou agora à vista de todos. É preciso perceber que o modelo das Fundações privadas com dinheiros públicos já não serve: a Casa da Música não pode ser mais uma parceria público-privada. A Casa da Música é serviço público, e o serviço público não é só oferecer concertos grátis. É ter princípios democráticos, cumprir a lei, cultivar a responsabilidade social. É perceber que a cultura é muitas coisas, mas não é isto.

Sara Didier, excertos da intervenção realizada na manifestação pública "Parados, nunca calados!", convocado pelo Sindicato dos TrabaIhadores de Espetáculos, do Audiovisual e dos

Músicos, CENA-STE, em conjunto com outras organizações do setor, 4 de junho de 2020

A 13 de março, a Casa da Música dispensou os nossos serviços, pura e simplesmente de um dia para o outro, todos os serviços que estavam agendados foram cancelados e não tivemos simplesmente nenhum pagamento sobre eles. Desde o dia 7 de abril, em que tivemos um e-mail do nosso coordenador e até final de maio, não houve nenhum contacto connosco. A única solução que nos deram foram os apoios da Segurança Social, apenas esses, para que nem todos estávamos elegíveis (...) Todos nós temos muito, muito gosto em trabalhar na Casa, mas sentimos que existe um desrespeito muito grande pelo nosso trabalho. Dizem-nos repetidamente que somos dispensáveis, que qualquer pessoa faz o nosso serviço, e depois sempre que há alguns eventos mais delicados mostram-nos a importância que o nosso serviço tem. Os assistentes de sala têm mais funções do que aquelas que a maior parte das pessoas imagina, e a Casa da Música tem mais eventos do que as pessoas pensam. Os assistentes de sala passam cerca de 16/18 horas por dia, todos os dias, na Casa da Música. Há eventos de manhã, à tarde e à noite 


\section{CADERNOS DAPANDEMIA $\underset{\text { SOCIOLOGIA }}{0}$}

e os assistentes de sala são sempre necessários para garantir a segurança e a logística da Casa. Toda a nossa equipa, todos os 44, são prestadores de serviços. Ou seja, é uma equipa que não tem nenhum elemento efetivo da Casa.

Hugo Veludo, assistente de sala, testemunho ao portal Esquerda.net, publicado a 6 de julho de 2020

O meu nome é José Vilela, sou técnico de palco e trabalho há 15 anos na Casa da Música. Ao longo deste tempo dediquei-me de corpo e alma a este projeto, até por ser a minha fonte exclusiva de rendimento, mas sobretudo porque sou apaixonado pelo que faço, e ninguém dentro daquela Casa poderá dizer, em consciência, que não fui sempre um profissional competente, dedicado e disponível, mesmo quando, comprovadamente, as necessidades da entidade patronal se sobrepunham às minhas, pessoais e familiares. Trabalhei muitas vezes 12, 14, 16 horas diárias, já cheguei a trabalhar 20h entre as 09h da manhã às O7h da manhã do dia seguinte sem muitas vezes me serem dadas sequer as horas de descanso que uma função como a minha requer. (...) Toda a gente ali me conhece, sou o Vilela. Veem-me lá todos os dias, falam comigo, atestam a minha importância, o meu conhecimento da Casa, a minha capacidade de adaptação às circunstâncias, a minha submissão aos desígnios superiores da instituição. Faço, como se costuma dizer, parte da mobília. E, no entanto, nunca me foi concedido o enquadramento laboral que por lei ninguém se atreverá a dizer que não me cabe. Seria um escândalo a ACT vir a concluir que não sou um falso recibo verde, porque evidências são evidências e nenhuma autoridade as poderá legitimamente negar. Por outro lado, de acordo com o que ouvi aqui nesta comissão, a administração da Casa da Música parece ignorar a mais-valia que é um trabalhador conhecer os cantos à Casa, ter experiência de trabalho dentro dela, estabelecer relações, lidar com as sensibilidades mais diversas, enfim, tudo o que contribui decisivamente para otimizar não apenas o exercício das minhas funções mas também auxiliar as de outros, porque nós todos interagimos, isto também é como uma orquestra. (...) [o meu chefe da coordenação] mostrou-se chateado com o abaixo-assinado dizendo: "Estás a entrar numa guerra que não é tua e num casamento que pode ter um divórcio. Toda a gente vai ter graves consequências, os da Casa não tanto, mas tu és recibos verdes, vais sofrer visto que agora tens uma filha pequena e namorada." Considero que isto que me foi dito foram ameaças concretas de represálias, e sinto que as estou a sofrer na pele ao não ser chamado para trabalhar, ao contrário dos meus colegas que retiraram o nome do abaixo-assinado depois de serem contactados pelo mesmo chefe de coordenação.

José Vilela, testemunho na audição pública realizada na Assembleia da República, 17 de junho de 2020 ("completado com o relato das ameaças que recebi", de acordo com o próprio, em e-mail enviado em junho de 2020)

\section{Serralves e Casa da Música: "não é a mesma casa, é a mesma causa"}

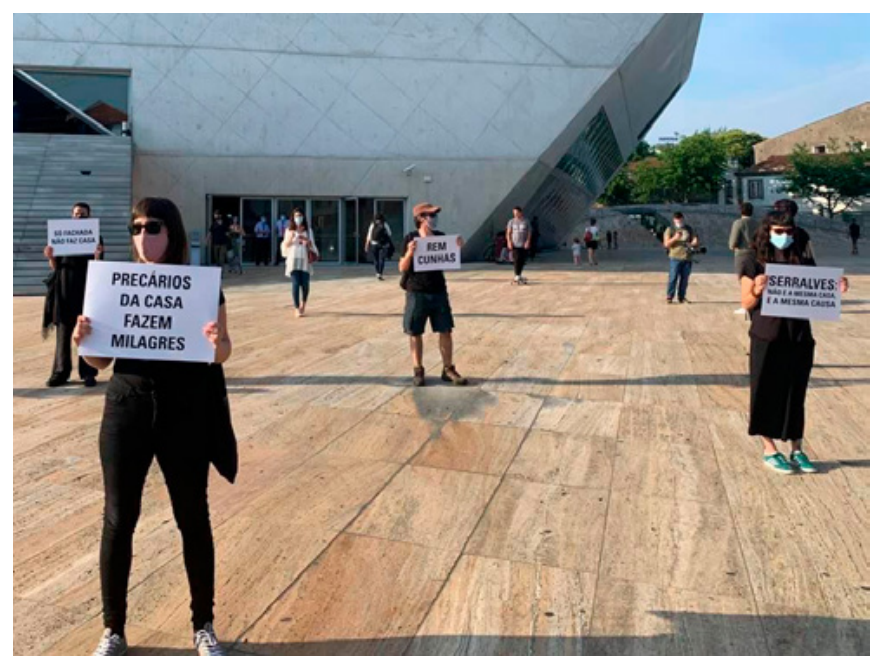

Figura 1 - Vigília de trabalhadores precários frente à Casa da Música. 1 de junho de 2020.

(José Soeiro @ 2020) 


\section{CADERNOS DAPANDEMIA $\underset{\text { SOCLIOLOGIA }}{\mathrm{INSTITUTO}}$}

A luta desenvolvida pelos trabalhadores precários da Fundação de Serralves e da Fundação Casa da Música é um extraordinário estudo de caso sobre as mobilizações sociolaborais do precariado, mas também sobre as práticas institucionais destas Fundações no que ao enquadramento do trabalho diz respeito. Em abono da verdade, é preciso dizer que não foi a primeira vez que trabalhadores a recibo verde destas instituições chamaram a atenção para a sua situação. Entre fevereiro e junho de 2010, por exemplo, os trabalhadores da receção do Museu de Serralves levaram a cabo uma luta, a que se juntou o grupo Fartos d'Estes Recibos Verdes, pelo reconhecimento dos seus contratos de trabalho. Entre outras coisas, esse processo, que faz agora dez anos, envolveu uma ação inspetiva da Autoridade para as Condições de Trabalho que daria razão aos trabalhadores; um abaixo-assinado de solidariedade subscrito por mais de 50 personalidades, sobretudo do mundo das artes, intitulado "O Museu como Projeto. Trabalhadores e Sociedade"; ações à porta da Fundação; e uma petição com mais de mil assinaturas. ${ }^{101}$ De facto, na primeira década dos anos 2000, Portugal assistiu à emergência de um campo de mobilizações e de uma galáxia de movimentos e associações que procuraram dar voz e representação a várias modalidades precárias de emprego invisibilizadas no espaço público e no próprio mundo laboral. Desse processo fizeram parte, por exemplo, o Stop Precariedade (nascido em 2002), a Associação de Bolseiros de Investigação Científica (criada em 2004), a Plataforma dos Intermitentes do Espetáculo e do Audiovisual (formada em 2006) e coletivos como o FERVE (Fartos d'Estes Recibos Verdes) ou os Precários Inflexíveis (ambos nascidos em 2007). ${ }^{102}$ O ciclo de ação coletiva que teve lugar entre 2012 e 2014 teria também na precariedade - e, dentro desta, no combate aos falsos recibos verdes - um dos seus pilares. Foi nesse contexto, aliás, que uma iniciativa legislativa

101 Para mais informação sobre este processo em particular, ver Soeiro, 2015, pp 263-265.

102 Procurei apresentar uma história deste processo na tese "A Formação do Precariado", apresentada em 2015, e disponível online. de cidadãos deu origem à chamada "lei contra a precariedade" (a Lei 63/2013, que institui a "ação especial de reconhecimento do contrato de trabalho"), instrumento central em todo o processo que envolve os precários de Serralves e da Casa Música em 2020.

A sequência de acontecimentos relacionados com a denúncia das práticas laborais destas duas instituições, impulsionada pela situação de absoluta desproteção em que dezenas de trabalhadores se encontraram na primavera deste ano, é um caso de estudo para o qual vale a pena olhar com atenção. Neste breve texto, proponho destacar - tecendo breves considerações sobre cada um deles - cinco aspetos que parecem ser particularmente importantes neste processo, quer do ponto de vista sociológico quer político: 1) a construção de formas de auto-representação do precariado destas instituições; 2) os repertórios de ação e a deslocação da luta laboral para o espaço público e mediático; 3) o tipo de reação dos conselhos de administração face à revolta dos precários; 4) as tensões e solidariedades geradas entre trabalhadores; 5) a centralidade do recurso à "ação especial de reconhecimento do contrato de trabalho".

\section{1) Contornar a precariedade da representação}

Um dos primeiros problemas com que os trabaIhadores a "recibo verde" de ambas as instituições se confrontaram foi com a inexistência de estruturas formais capazes de representá-los. O problema não é novo, mas estes casos expuseram-no. Como se argumentou anteriormente, a precarização não é apenas uma estratégia de compressão dos custos do trabalho e de dominação pelo medo: é também uma forma de desarticular os mecanismos de representação coletiva de quem trabalha. Ora, ao serem remetidos para a condição de "externos" pelas instituições, a estes trabalhadores estão na prática vedados dispositivos como as Comissões de Trabalhadores (existentes em ambas as instituições). Este vazio de representação formal foi explorado, de resto, quer pelas administrações (que alegavam ter cumprido e dialogado com os trabalhadores que reconheciam 


\section{CADERNOS DAPANDEMIA $\underset{\text { SOCLIOLOGI }}{\mathrm{INSTITUTO}}$}

como sendo aqueles para com quem tinham responsabilidade), quer por alguns partidos (que procuraram deslegitimar a presença dos "grupos de precários" no Parlamento, questionando a sua representatividade), quer até por um grupo de "Trabalhadores do Quadro da Casa da Música" (que escreveu um comunicado a demarcar-se dos colegas a recibo verde).

Quer num caso quer noutro, contudo, os trabaIhadores a recibo verde constituíram grupos informais que assumiram a representação coletiva dos precários e a organização de iniciativas públicas com grande ressonância. O facto de estes grupos nunca terem sido objeto de qualquer tipo de reconhecimento por parte das Administrações não os impediu, pois, de conquistar a legitimidade de facto para a representação desta realidade. Tendo encontrado as suas formas de organização - mais fluídas e informais, com uma estrutura que era, aparentemente, pouco mais do que um e-mail e alguns fóruns de discussão - e tendo encontrado as suas formas de deliberação, os grupos informais de precários foram reconhecidos como porta-vozes desta realidade, o que ficou patente, por exemplo, nas múltiplas intervenções nos media ou quando tomaram a palavra nas audições públicas no Parlamento. ${ }^{103}$

\section{2) Projeção pública, repercussão mediática e alianças sociais: repertórios de luta para inverter a relação de forças}

Como sucedeu com outras lutas de trabalhadores precários, também nestes casos, para contrariar a desigualdade da relação de forças dentro do espaço das instituições (onde foram remetidos à condição de "externos" e onde não dispunham dos canais formais de diálogo com as respetivas

103 Os trabalhadores precários da Casa da Música foram recebidos pela Comissão Parlamentar de Trabalho e Segurança Social a 17 de junho de 2020. O grupo de precários de Serralves foi ouvido na mesma Comissão a 23 de setembro do mesmo ano. O registo vídeo de ambas as audições pode ser encontrado na secção "Comissões" do sítio online canal.parlamento.pt. administrações), estes grupos de precários lançaram mão de um eclético repertório de luta que envolveu também uma operação de deslocação do terreno do conflito de dentro da instituição para fora dela. Isso fez-se procurando ocupar o mais possível o espaço público, com vigílias e concentrações (duas à porta da Casa da Música, a 1 e a 6 de junho, ${ }^{104}$ e uma à porta de Serralves, a 5 de julho de 2020) e o espaço mediático, potenciado como lugar de amplificação das suas tomadas de posição, designadamente pela divulgação pública de comunicados, cartas-abertas e abaixo-assinados. ${ }^{105}$

A tentativa de reverter o profundo desequilíbrio de forças no quadro interno das suas instituições implicou também um intenso trabalho de interlocução e de construção de alianças, quer no campo da política institucional (com reuniões e diálogos com os partidos políticos e com as Comissões Parlamentares), quer no campo cultural. No primeiro

$104 \mathrm{Na}$ primeira vigília de trabalhadores frente à Casa da Música, no dia do primeiro concerto de reabertura ao público daquele equipamento, dezenas de trabalhadores da Casa da Música e de Serralves empunham cartazes onde se lê: "Precários da Casa fazem milagres", "Rem Cunhas", "Administradores brilhantes, precários a pedantes", "Precário e bem há pouco quem", "Serralves: não é a mesma casa, é a mesma causa", "Espetáculo da Precariedade", "À volta do Bacoco". "Só fachada não faz Casa", "Casa da Música e Serralves: Juntxs já não Somos Poucxs". A 6 de junho, realizou-se uma vigília silenciosa, na praça da Casa da Música, "contra o silêncio com que a Administração nos desconsidera. 50 dias sem resposta". Na convocatória, anuncia-se "uma manifestação de repúdio por todos os atos de intimidação e represálias sobre qualquer trabalhador da Casa da Música, efetivo ou a recibo verde".

105 Além dos inúmeros comunicados públicos dos dois grupos, com repercussão na imprensa, foram também divulgadas cartas e abaixo-assinados de solidariedade. A 4 de maio, por exemplo, é divulgada uma "Carta Internacional" em defesa dos educadores e outros trabalhadores precários em museus, na qual se referem os casos de Serralves, do MomA e la MOCA. A 2 de outubro, os precários da Casa da Música divulgam um abaixo-assinado dirigido aos membros do Conselho de Administração, em que se exorta ao cumprimento da notificação da ACT e à regularização imediata dos 21 'falsos recibos verdes' identificados pela autoridade inspetiva. "Em menos de 24 horas", anunciaram os promotores, mais de 1200 pessoas tinham subscrito a "Carta Aberta ao Conselho de Administração". Quando foi entregue, tinha mais de 2500. 


\section{CADERNOS DAPANDEMIA $\underset{\text { SOCLIOLOGIA }}{0}$}

caso, o exemplo mais eloquente da importância dessa interlocução política é provavelmente o efeito do conjunto de audições realizadas no Parlamento, que projetaram nacionalmente a luta destes trabalhadores, obrigando os agentes políticos (nomeadamente o Governo e os partidos), os organismos do Estado (designadamente a Autoridade para as Condições do Trabalho) e os próprios Conselhos de Administração a posicionarem-se publicamente sobre a situação. No segundo caso, a dinamização de abaixo-assinados, nomeadamente mobilizando nomes do campo cultural (sobretudo no caso de Serralves, com a existência de uma carta internacional com 1500 subscritores divulgada em maio e de um abaixo-assinado com mais de 2500 assinaturas tornado público em outubro), permitiu também projetar aquela luta para além das fronteiras do Fundação - transportando-a para o território da cidade e do país e para o campo artístico internacional.

\section{3) Negar, retaliar, litigar: a posição dos Conselhos de Administração}

A reação dos responsáveis destas instituições, tendo tido nuances importantes, teve também elementos simétricos. Num primeiro momento, tratou-se de negar a existência de um problema que coubesse às próprias instituições resolver, seja relembrando que os trabalhadores em causa não tinham vínculo com a instituição ("os prestadores de serviços externos, nomeadamente os monitores do serviço educativo, não têm vínculo laboral com a Fundação de Serralves, colaborando com várias outras entidades e prestando os seus serviços de acordo com as solicitações e necessidades da Fundação e a sua própria disponibilidade", lê-se num comunicado do início de abril), seja remetendo eventuais soluções para a Segurança Social ("o Estado está a garantir medidas de apoio no contexto da crise em que vivemos"), seja insistindo que as obrigações legais estavam a ser cumpridas ("Serralves está a cumprir todas as suas obrigações para com os seus colaboradores", refere o mesmo comunicado da Administração).
Num segundo momento, com o problema exposto no espaço público, a estratégia foi de pressão e retaliação. Por um lado, incitando os trabalhadores a retirar a sua assinatura do abaixo-assinado para não "arranjarem problemas" (tal como relatado no testemunho de um trabalhador da Casa da Música, transcrito no ponto anterior), estratégia que teve sucesso em alguns casos. Noutros casos, retirando o serviço agendado aos trabalhadores que tinham manifestado incómodo com a Administração. ${ }^{106}$ Finalmente, como foi denunciado pelos arte-educadores de Serralves, procurando substituir aqueles trabalhadores por outros, na fase da retoma. ${ }^{107}$ Este comportamento foi assumido de forma quase unânime, com a honrosa exceção, na Casa da Música, do Maestro Borges Coelho. ${ }^{108}$

Quando as Administrações foram, por fim, confrontadas com as conclusões de ações inspetivas

106 No dia 8 de junho, realiza-se uma reunião do Executivo da Câmara do Porto (CMP), que aborda o tema da Casa da Música, com a presença de Luis Osório (deputado municipal do PSD e representante nomeado pelo município no Conselho de Administração). Rui Moreira, presidente da CMP, informa ter estabelecido contactos com Valente de Oliveira (presidente do Conselho de Fundadores), Graça Fonseca (Ministra da Cultura) e José Pena do Amaral (presidente do Conselho de Administração). Na ata da reunião pode ler-se que foi dada a informação, à CMP, que a direção da Casa da Música "achou mais avisado que os prestadores de serviços que assinaram o abaixo-assinado não fossem considerados nas escalas de serviço". Lê-se ainda que teria "chegado essa informação ao Conselho de Administração, que se opôs à ideia". O Executivo municipal recomendou formalmente ao Conselho de Administração "uma análise prudencial dos contratos de prestação de serviço que possam configurar relações de trabalho".

107 No dia 17 de junho, um comunicado dos trabalhadores precários de Serralves denunciou que "estão já a decorrer entrevistas na Fundação de Serralves para novos educadores".

108 A 9 de junho, o Maestro Borges Coelho, um dos representantes do Estado no Conselho de Administração da Casa da Música, escreveu uma carta à Ministra da Cultura, colocando o lugar à disposição e fazendo depender a sua continuidade da resolução da situação dos precários, da abertura de canais de diálogo com os trabalhadores e do reconhecimento de uma representação dos trabalhadores no Conselho de Administração. No dia, 18 de junho, em comunicado, anuncia: "Não tendo recebido até à data o mais leve sinal da tutela, renuncio a partir de hoje ao meu lugar no Conselho de Administração". 
CADERNOS

DAPANDEMIA

$\overbrace{\text { IIPORTO }}^{\text {SNSTITUTO OE }}$

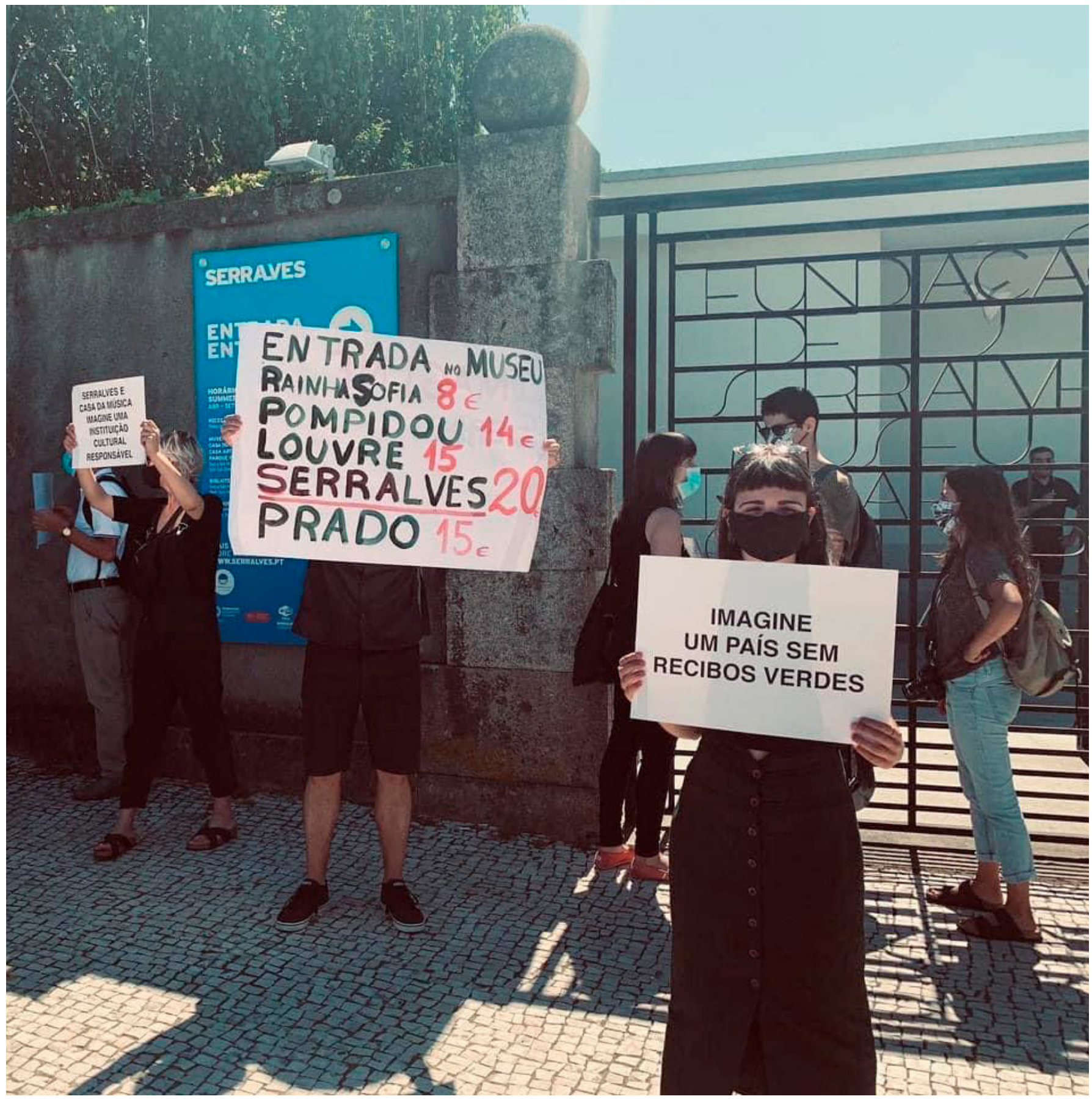

Figura 2 - Concentração frente à Fundação de Serralves. 5 de julho de 2020.

(José Soeiro (c) 2020) 


\section{CADERNOS DAPANDEMIA $\underset{\text { SOCLIOLOGIA }}{\mathrm{INSTITUTO}}$}

da Autoridade para as Condições de Trabalho que deram razão aos trabalhadores (o que aconteceu nos dois (asos), a sua primeira reação foi não acatar as notificações daquele organismo do Estado, fazendo com que se iniciassem as "ações de reconhecimento do contrato de trabalho" em Tribunal, com o Ministério Público a defender a regularização e o reconhecimento dos contratos de trabaIho dos "falsos recibos verdes". Em Serralves foi anunciada, em setembro deste ano, a intenção de litigar contra a posição do Ministério Público, para manter os "falsos recibos verdes". A Casa da Música, por seu turno, e já depois de a ACT ter encaminhado os processos para o Ministério Público, propôs aos trabalhadores contratos que, na sua maioria, foram considerados inaceitáveis por estes, correndo assim o processo em tribunal.

\section{4) Tensões e solidariedades entre trabalhadores}

Os acontecimentos recentes em Serralves e na Casa da Música são também um ponto de observação interessante acerca dos efeitos da fragmentação de estatutos laborais entre os próprios trabalhadores. É sabido que, do ponto de vista gestionário, essa estratégia tem frequentemente como objetivo incitar uma dinâmica de competição, de concorrência entre iguais e de dominação pelo medo. Em ambos os casos, é um facto, as respetivas Comissões de Trabalhadores, em que estão representados os trabalhadores com vínculo às instituições, não tomaram posição pública pela plena integração dos precários. Na Casa da Música chegou mesmo a ser elaborado e divulgado, no dia em que o Conselho de Administração foi ouvido no Parlamento, um comunicado de um grupo de 62 trabalhadores, identificados como "Trabalhadores do Quadro da Fundação Casa da Música”, que pretendia demarcar-se do abaixo-assinado de abril, declarando: "Temos a obrigação de esclarecer que o autointitulado 'Grupo de Trabalhadores da Casa da Música' não é representativo do sentir e pensar da larga maioria das pessoas que trabalham nesta Casa. E que a sua estratégia de destruição da reputação da casa da Música, do seu projeto artístico e de quantos nele trabalham nos revolta".
No entanto, ao mesmo tempo que, internamente, era possível identificar a tensão entre diferentes grupos de trabalhadores, houve também várias demonstrações de solidariedade entre trabalhadores com condições laborais diferentes (o abaixo-assinado de 18 de abril, em defesa dos precários, contava com a assinatura de "28 trabalhadores com contrato") e entre trabalhadores a recibo verde das duas instituições, que passaram a marcar presença nos protestos uns dos outros e desenvolveram em conjunto, por exemplo, o "projeto Fulano B", responsável pela divulgação da música "Abraço Assinado", uma canção de Manel Cruz e Sara Yasmine, feita em colaboração com estes trabalhadores, que dão a cara num vídeo de André Gil Mata, com palavras projetadas pelo artista visual Miguel Januário nas paredes do edifício de Rem Koolhaas.

\section{5) A "Ação Especial de Reconhecimento do Contrato de Trabalho": a lei como instrumento de luta}

Nascida na sequência das mobilizações da Geração à Rasca, em 2012, a Lei 63/2013 desempenhou um papel fundamental neste processo. Em que consiste, afinal, este objeto jurídico singular que nasceu da mobilização dos movimentos de precários? Na prática, esta lei estabeleceu um mecanismo expedito através do qual a própria Autoridade para as Condições do Trabalho, utilizando o método indiciário, pode dar origem ao reconhecimento de relações de trabalho subordinado dissimuladas e no qual o Ministério Público assume o interesse público desta causa. Ou seja, trata-se de uma lei de combate aos "falsos recibos verdes" que, ao invés de fazer recair sobre o trabalhador precário o ónus de pôr a sua entidade patronal em tribunal para que esta lhe reconheça o contrato, coloca essa responsabilidade na alçada do próprio Estado.

A chamada "presunção de laboralidade" está definida no art. 12. do Código de Trabalho. Desde 2009 que, pela lei, se presume existir um contrato de trabalho sempre que se verifiquem algumas (ou seja, pelo menos duas) destas características: uma atividade realizada "em local pertencente 


\section{CADERNOS DAPANDEMIA $\underbrace{\text { INSTITUTO DE }}_{\text {UUPORTO }}$}

ao seu beneficiário ou por ele determinado"; "os equipamentos e instrumentos de trabalho utilizados pertençam ao beneficiário da atividade"; "o prestador de atividade observe horas de início e de termo da prestação, determinadas pelo beneficiário da mesma"; "seja paga, com determinada periodicidade, uma quantia certa ao prestador de atividade, como contrapartida da mesma"; "o prestador de atividade desempenhe funções de direção ou chefia na estrutura". Se alguns destes indícios forem observados, presume-se a existência de uma relação laboral, por definição, dependente, subordinada.

A Lei 63/2013, de 27 de agosto, veio definir este mecanismo de regularização do falso trabalho independente que deu um papel acrescido à ACT e uma nova responsabilidade ao Ministério Público. Apesar do alcance desta "ação especial de reconhecimento do contrato de trabalho" estar muito dependente dos meios inspetivos (e, por isso, limitado pela falta de recursos da ACT), o facto é que ela já deu origem a muitas centenas de regularizações e tem sido, ao longo destes anos, um instrumento central em várias lutas de trabalhadores a recibo verde, que alcançaram por esta via o reconhecimento da sua relação laboral.

Tabela 1: A aplicação da Lei 63/2013 em números

\begin{tabular}{|c|c|c|c|c|}
\hline$\stackrel{\circ}{\frac{1}{4}}$ & 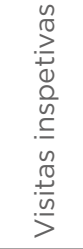 & 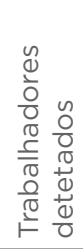 & 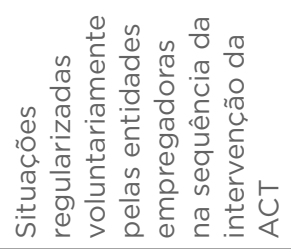 & 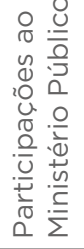 \\
\hline 2014 & 1.364 & 1.510 & 507 & 425 \\
\hline 2015 & 1.124 & 478 & 291 & 64 \\
\hline 2016 & 903 & 559 & 84 & 37 \\
\hline 2017 & 587 & 592 & 288 & 317 \\
\hline 2018 & 992 & 484 & 158 & 182 \\
\hline 2019 & 1.698 & 185 & 118 & 92 \\
\hline
\end{tabular}

Fonte: MTSS, 2020

\section{O princípio de um fim?}

No momento em que é escrito este texto, alguns dos trabalhadores precários da Casa da Música tiveram já o seu "falso recibo verde" convertido em contrato de trabalho. A maioria, no entanto, quer na Casa da Música quer em Serralves, aguarda o desfecho do seu processo em tribunal, nomeadamente perante a recusa, por parte dos administradores, em cumprir as notificações da ACT, o que não deixa de ser revelador do quanto os próprios Conselhos de Administração destas e de outras instituições se sentem acima dos organismos do Estado que têm como missão garantir o cumprimento das leis do trabalho.

Em Portugal, é facto, a precarização disseminou-se, grandemente, através do hiato profundo entre a lei escrita e a lei efetivamente praticada, o que faz com que a mera exigência da aplicação da lei envolva já um conflito intenso com o poder e uma luta transformadora. Por isso, não surpreende a importância, nestas lutas, do recurso ao direito e da utilização estratégica da "Lei de combate à precariedade", sempre articulada com ações complementares (comunicados públicos, denúncias ao media, manifestações no espaço público, interpelação das instituições políticas), determinantes para impulsionar os próprios processos inspetivos. ${ }^{109}$

Serralves e Casa da Música não são, contudo, casos isolados no panorama cultural em Portugal. A mobilização destes dois grupos de trabaIhadores destapou uma realidade que é muito mais generalizada e relativamente à qual tem prevalecido uma espantosa impunidade. Em todo o setor da cultura, dos espetáculos e do audiovisual, abunda o recurso ao falso recibo verde e ao falso outsourcing. O exemplo dado pelos precários destas duas instituições parece estar, no entanto, a despertar outras denúncias e uma maior consciência dos direitos e dos instrumentos disponíveis

109 No caso de Serralves, depois de um primeiro relatório inspetivo em que a $\mathrm{ACT}$, tomando como única fonte a própria Administração, afirmava não ter encontrado "falsos recibos verdes" na instituição, há um volte-face e, mudando de posição, a autoridade inspetiva acabaria por dar razão aos trabalhadores. 


\section{CADERNOS}

DAPANDEMIA

0 INSTITUTO DE

para realizá-los. Não seria uma surpresa, por isso, se os próximos tempos vissem eclodir processos semelhantes noutros espaços. Estaríamos, neste caso, a assistir ao princípio do fim da cultura dos recibos verdes na cultura?

\section{Outubro de 2020}

O autor segue as normas do Acordo Ortográfico da Língua Portuguesa de 1990.

\section{Referências bibliográficas}

Caldas, J. C.; Silva, A. A.; Cantante, F. (2020). As consequências socioeconómicas da COVID-19 e a sua desigual distribuição. Lisboa: CoLABOR.

GEP (2020). Indicadores COVID-19. Ministério do Trabalho, da Solidariedade e da Segurança Social.

INE (2020). Inquérito ao Emprego.

Leite, J. (2013). A Reforma Laboral em Portugal. Revista General de Derecho del Trabajo e de Seguridad Social, n. 34.

Soeiro, J. (2015). A Formação do Precariado. Tese de Doutoramento em Sociologia: Relações de Trabalho Desigualdades Sociais e Sindicalismo. Coimbra: FEUC.

Pedroso, P. (2020). Desigualdades Sociais. In Mamede, R. P. e Silva, P. A. (org.), O Estado da Nação 2020: Valorizar as Políticas Públicas. Lisboa: IPPS - Iscte - Instituto para as políticas Públicas e Sociais.

OIT (2018). Trabalho Digno em Portugal 2008-18: da crise à recuperação. Genebra: Bureau Internacional do Trabalho. 


\section{ALGUMAS REFLEXÕES SOBRE ISTO DE SER MÚSICO EM TEMPO DE PANDEMIA (PEQUENO TESTEMUNHO)}

\section{Capicua*}

E aos quarenta e tal dias de quarentena fui-me abaixo.

Não foi sequer pelos dias de clausura pesarem no espírito. Nem o facto de a quarentena ter virado cinquentena. Muito menos a falta de vida social. Foi mesmo a perspectiva de que não será fácil o regresso à normalidade. Porque a normalidade agora é inviável e será até haver vacina. E, claro, sem uma vacina para nos devolver as multidões, os músicos não terão trabalho.

A perspectiva de cancelamento da agenda deu-se num momento ingrato para todos e especialmente para mim. Aconteceu em pleno recomeço da actividade anual dos músicos (porque Janeiro e Fevereiro são sempre meses de poucos concertos) e em pleno início de digressão do novo disco, que consegui terminar à custa de muito sangue, suor e lágrimas (durante uma gravidez e um pós-parto).

Apesar do balde de água fria, toda a classe percebeu a importância de evitarmos aglomerações de pessoas e, mesmo antes das recomendações oficiais, prontamente foram cancelados todos os concertos. Acho que tivemos esperança de que uma quarentena atempada nos roubasse o início da primavera, mas garantisse o verão (altura de maior trabalho, em que amealhamos o sustento dos meses de inverno, como as formigas).

Ora, em plena quarentena, já com a primavera comprometida, percebemos que não teríamos trabalho no verão e que, só a muito custo, poderiam existir eventos no resto do ano, sempre sem certezas. É que a perspetiva de novo surto no inverno, compromete muito o vislumbre de outono e temo que só no próximo ano a coisa possa voltar a estar de feição para quem, como eu, faz a vida no palco.

A frase que se repete por aí é verdade: os trabalhadores da cultura foram os primeiros a ficar sem trabalho por causa da pandemia e serão dos últimos a regressar ao activo na plenitude. São também dos mais precários. Toda uma indústria de trabalhadores independentes, e quase sempre

\section{CADERNOS DAPANDEMIA - INSTITUTODE}

sazonais, muito empenhados e qualificados, mas esquecidos nos bastidores.

Para terem uma ideia, para que eu possa subir ao palco, há uma equipa de catorze pessoas que se mobiliza (entre músicos e técnicos). Para além das pessoas que trabalham na agência que marca os concertos, dos trabalhadores da empresa que monta o palco e instala o sistema de som, e do pessoal da produção, da programação, da promoção... Um exército de trabalhadores que fazem de tudo para que, à hora marcada, haja espectáculo, com todas as condições necessárias para que a magia aconteça e o público saia satisfeito.

Todas essas pessoas ficaram sem trabalho e todas essas pessoas têm famílias, pagam casa, vão ao supermercado, recebem contas da luz, existem enquanto cidadãos de bem, que pagam (muitos) impostos e segurança social todos os meses (exageradamente), na sua maioria na qualidade de trabalhadores a recibos verdes, sem direito a qualquer protecção em horas de escassez.

Bem sei que o Estado deu umas ajudas, simbólicas, através da Segurança Social, mas que além de pequenas não cobriram a imensidão de trabalhadores do sector. Que instituições como a Gulbenkian e a Câmara de Lisboa, prometeram apoios, mas só para alguns. Que a GDA e a SPA tentaram apoiar artistas e autores, mas que muitas equipas ficaram de fora. E que os pequenos impactos desses parcos apoios, para tanto tempo sem trabalho, resultaram em situações dramáticas para muitas famílias.

É preciso pensar, quanta dessa massa crítica sobrará no fim, quantos desses trabalhadores qualificados e com anos de experiência não perderemos para outras profissões durante estes longos meses e quantos artistas desistirão. É caso para pensar, que preço pagará o país pelas perdas incalculáveis (de talento, saber e profissionalismo) no sector da cultura e quantos anos demoraremos a recuperar.

É que além da incapacidade financeira e política do Ministério da Cultura, que muita vergonha alheia nos fez passar com avanços e recuos, drinks de fim de tarde e quase-programas-de-TV em esquema de pirâmide, a ajuda financeira prestada, num primeiro momento, foi a concurso e por proposta de novas criações. Foi quase como se, perante um mendigo a pedir esmola na rua, 


\section{CADERNOS DAPANDEMIA SOCIOLOGIA}

exigíssemos um truque ou pequena performance em troca. Foi quase como se, mesmo na hora do desespero, só fossemos dignos de apoio provando a nossa inventividade e capacidade criativa...

E o sector bem se esforçou. Depressa surgiram as tentativas de manutenção de relevância online, através de espectáculos caseiros nas redes sociais. Que, num primeiro momento, foram estimulados pela boa intenção de incentivar as pessoas a permanecerem em casa e fazer companhia a quem estava confinado, mas depressa se vulgarizaram, contribuindo ainda mais para banalizar o próprio trabalho artístico, sobretudo na música.

As pessoas já não estão habituadas a pagar para ouvir discos, desde o advento da pirataria online. Os músicos têm o seu rendimento reduzido aos espectáculos ao vivo e aos direitos de autor. E, de repente, em dois meses de quarentena, os concertos passam a ser oferecidos em catadupa, gratuitamente, no conforto do lar.

Claro que houve uma minoria de artistas famosos que o fez em parceria com marcas patrocinadoras, e também uma minoria de músicos diligentes que o fez em esquema de crowd funding, com o público a contribuir com donativos ou mesmo comprando bilhetes eletrónicos, mas deve ser dito que a maioria contribuiu apenas para a banalização e para o desgaste do formato e do consumo de música ao vivo.

Houve também quem buscasse outras alternativas, assim que começou o desconfinamento e passou a ser autorizada a realização de espectáculos com lotação limitada e cumprindo as normas de segurança impostas pela DGS. Os concertos em drive-in, em que a experiência imersiva dos habituais concertos é substituída pelo confinamento do carro e a audição da música através do auto-rádio. Ou mesmo os concertos em camiões, em modo palco itinerante, em trânsito pelas ruas das localidades para evitar os ajuntamentos, mas impedindo obviamente o normal acompanhamento do espectáculo. Sem esquecer, ainda, uma irrisória minoria de espectáculos em sala, sem público, mas com todas as condições técnicas, emitidos pela internet ou pela televisão.

Já os mais conservadores, cingiram-se à possibilidade dos espectáculos com lotação limitada, mas apesar da necessidade de voltar ao trabalho, muito poucos músicos regressaram ao palco, por duas razões essenciais. Primeiro porque a lotação limitada inviabiliza grande parte das produções e muito poucos músicos e promotores se podem dar ao luxo de arriscar perder dinheiro num ano difícil como este. E, segundo, porque os municípios têm mostrado uma grande retração, temendo ser pioneiros no regresso à normalidade, num contexto em que a própria opinião pública parece ver com bons olhos o clima de restrição securitária na programação cultural.

Isto sobretudo após o surto que atacou a Grande Lisboa depois do desconfinamento, expondo a pobreza, a falta de condições de trabalho, a segregação territorial, a concentração habitacional e a saturação dos transportes públicos, nas periferias da capital. O surto, disse-nos mais sobre o (sub) desenvolvimento do país, do que sobre a pandemia, mas (ironicamente) veio reforçar um discurso latente, de que precisamos de medidas musculadas para conter este problema. Em vez de discutirmos as condições de vida destas franjas da população, foram rápidos os dedos apontados à suposta inconsciência dos jovens, com a sua necessidade de lazer.

Parece ser aceitável que se corra risco de vida para trabalhar, na linha de montagem, na obra ou mesmo no autocarro, mas clama-se pelo recolher obrigatório que impedirá o usufruto do tempo livre (lá está) em liberdade. São cada vez mais populares as proibições e adiamentos de espectáculos, mesmo que com lotação limitada, distanciamento social assegurado e muitas vezes ao ar livre, como se fosse pecado querer absorver cultura num momento destes. Ou mesmo como se o vírus apenas atacasse os ociosos. Sem perceber que, quanto mais proibimos o lazer em espaços controlados e cumpridores das orientações da DGS, mais estimulamos as festas e ajuntamentos informais, domésticos ou em lugares com poucas condições de segurança. Sem perceber que, num momento tão delicado da nossa economia, boicotar a cultura, já bastante moribunda, demonizando-a ou reforçando a ideia que é supérflua e evitável, é matar um sector que cria empregos, atrai turistas e mantém a nossa saúde mental. 


\section{CADERNOS DAPANDEMIA 0 INSTITUTO DE}

A turba das redes sociais, o tom dos jornalistas televisivos, as bocas nos cafés, apoiam as proibições, clamam por controlo apertado, insurgem-se contra eventos organizados com todas as condições e apoiam atitudes autoritárias e populistas de autarcas com tiques de tiranete.

Resumindo, temos uma crise pandémica sem data para terminar. Temos um Ministério da Cultura incapaz (política e tecnicamente) e sem orçamento para fazer face aos danos causados no sector. E temos muita luta a fazer, à porta do Ministério do Trabalho e Segurança Social, para exigir que o estatuto do trabalhador da cultura, precário, sazonal e intermitente, seja, como em França, alvo de um tipo de protecção mais digno e adequado às necessidades da classe.

Sei que ainda há quem ache que a Cultura é um sector menor e que a Arte não é bem essencial. Há muito quem acuse os artistas de comiseração e parasitismo. Quem ache que isto é um hobby e não uma profissão. Boçalidade e tecnocracia, normalmente alinhadas com ideologias pouco democráticas e pouco amigas da mundivisão e do espírito crítico, da inspiração e dos corações ao alto. E acrescento que seria muito interessante ver quantos sobreviveriam a uma quarentena de dois meses sem música, filmes ou séries, livros e outras formas de arte.

Ainda assim, sinto que isto de depender financeiramente da música é, de facto, muito estúpido, num tempo em que as perspectivas de rendimento são escassas. Penso muitas vezes que o nosso maior desafio, enquanto coletivo, além da concretização do estatuto de trabalhador intermitente, seria diversificar as nossas fontes de rendimento, por uma questão de justiça (porque há muito quem ganhe com a nossa música, enquanto a oferecemos) e por uma questão de sobrevivência. Amo-a demais para depender dela, como dizia Carlos Paredes, mas sinto que ela me exige todo o tempo e toda a dedicação, amando-a demais para não viver para ela, como dizia o Sam the Kid.

Isto que estamos a viver é, de facto, um divisor de águas. Em pouco tempo reinventámos a etiqueta e o protocolo. Repensámos a mobilidade urbana e a organização do trabalho. A educação, as rotinas e prioridades de consumo. Transformámos os hábitos de socialização e lazer. Substituímos muita coisa que achávamos insubstituível e, no processo, revalorizamos muitas coisas dadas como garantidas. O toque, o abraço, a jantarada enquanto instituição nacional, o êxtase de um concerto ao vivo, a alegria das festas populares que não vamos ter, as idas para o trabalho à janela do autocarro, o cafezinho com o colega, e até a praia como bem de acesso ilimitado.

Ora, perante tanta disrupção, a arte que criarmos a partir de agora terá de ser necessariamente diferente, se quiser estar embebida do espírito da época. Tal como terá de ser diferente a nossa relação com a profissão de artista. Há que rever e reinventar. Adaptar, recomeçar, alinhar o azimute com o depois de amanhã e perceber que, tal como a natureza que se regenera fulgurante com todo este abrandamento, poderemos $\mathrm{nm}$ se,ica e tecnicamente fim.seguirmos continuar a se com todo este abrandamento, poderemos reflorescer artisticamente, se ainda ós também reflorescer artisticamente e repensar a nossa forma de trabalhar e gerar sustento. Isto se ainda conseguirmos ser artistas (vivos e no activo) no fim.

\section{Agosto de 2020}

*A autora segue as normas do Acordo Ortográfico da Língua Portuguesa de 1990. 


\section{CADERNOS DAPANDEMIA SOCIOLOGI}

\section{O JOGO DO DESCONFINAMENTO}

\section{Regina Guimarães}

\section{um jogo de escolhas a jogar a solo e à suivre em que o jogador joga com e contra si mesmo}

Precisas mais duma carta de amor ou dum extracto mensal de conta? Precisas de mais uma noite de verão ou de mais um candeeiro design? Precisas mais de sopa de legumes ou de suplementos alimentares? Precisas de mais um parque arborizado ou de mais um parque de estacionamento? Precisas mais da conversa no café ou dos tweets dos poderosos analfabetos? Precisas de mais uma mercearia gourmet ou de mais um mercado de frescos? Precisas mais dum consultor de imagem ou duma consulta no médico de família? Precisas de mais escolas livres e gratuitas ou de mais coaching e de gestores de talentos? Precisas mais de hospitais públicos ou de bancos de investimento? Precisas de mais dramaturgos sem travão ou de mais opinion makers? Precisas mais de prados e florestas ou de cenários virtuais sofisticados? Precisas de mais filósofos na rua ou de mais influencers na net? Precisas mais de serras e oceanos ou de paisagismo planificado? Precisas de mais companheiros ou da companhia de mais hipsters? Precisas mais de diversidade biológica ou de transumanismo galopante? Precisas de mais geografias rebeldes ou de mais geolocalização dos párias? Precisas mais do conto a cada encontro ou do story-telling da netflix?

Precisas de mais do teu preciso tempo ou de mais tempo para money-making? Precisas mais de ler e andar nas nuvens ou de alimentar o éter da tua cloud? Precisas de mais companheiros de estrada ou de mais likes no facebook?
Precisas mais do saber-fazer do lavrador ou das performances do analista de big data? Precisas de mais instantes inimagináveis ou de mais fotografias no instagram? Precisas mais de ideias para mudar mundo ou dos softskills dum Scrum master? Precisas de mais professores talentosos ou de mais horas de e-learning? Precisas mais da fantasia duma horta louca ou de roupa trendy e acessórios tendance? Precisas de mais ver melhor o que te olha ou de mais selfies em toda a parte e hora? Precisas mais do café do teu bairro ou duma casa de chá rétro na baixa? Precisas de mais gente a bater à tua porta ou de mais aplicações no teu smartphone? Precisas mais da sombra das árvores ou dum bunker com todas as comodidades? Precisas de mais bancos de jardim ou de mais garantias de sigilo bancário? Precisas mais de paraísos fiscais ou de mais paraísos artificiais? Precisas de mais saltimbancos ou de câmaras de vídeo-vigilância? Precisas mais de cantinas comunitárias ou de templos da nouvelle cuisine? Precisas de mais contraditores ferozes ou de mais animais de estimação? Precisas de mais funambulismo na mioleira ou de mais arame farpado na fronteira? Precisas mais de ver crianças a brincar na rua ou de visitar dreamlands e parques temáticos? Precisas de mais razões para uma longa vida ou de mais lazer e escapismo organizado? Precisas mais de quem te ouça e console ou dos videojogos da consola? Precisas mais de brincar aos cozinhados ou de oscilar entre low-food e fast-food? Precisas de mais memória para pensar ou de mais ram para te esqueceres disso? 


\section{CADERNOS DAPANDEMIA $\underbrace{0}_{\text {UPORTO }}$ SOCIOLOOGIA}

\section{Notas biográficas}

\section{Amarílis Felizes}

Dirigente da Plateia - Associação de Profissionais das Artes Cénicas, coordenadora de produção da companhia de teatro Visões Úteis e aluna da edição pioneira do Doutoramento Interdisciplinar em Economia Política (ISCTE, FEUC e ISEG-UL), Amarílis é mestre em Economia e Políticas Públicas pelo ISEG-UL, com a dissertação "Política Cultural em Portugal - Determinantes da despesa pública em cultura". licenciada em Economia pela FEP e licenciada em Teatro pela ESMAE - IPP. Entre outros temas, tem investigado as políticas culturais, as políticas económicas, as desigualdades e as finanças públicas. Colaborou recentemente no relatório "O Estado da Nação e as Políticas Públicas 2020" - IPPS - ISCTE e assinou o prefácio de "O Governo das Desigualdades" de Maurizio Lazzarato, editado em 2020. Co-autora de um capítulo do "The Routledge Companion to Theatre of the Oppressed", tem formação consistente e experiência nas metodologias do Teatro do Oprimido, criado por Augusto Boal, bem como no Teatro Dialético de Bertolt Brecht. Entre 2015 e 2018 foi assessora política para as áreas da Cultura, Economia e Finanças no Grupo Parlamentar do Bloco de Esquerda.

\section{Capicua}

Capicua nasce no Porto nos anos 80, descobre a cultura Hip Hop nos anos 90 (primeiro pelo Grafitti e depois pela música), passando de mera ouvinte a aprendiz de Rapper nos anos 00. Socióloga de formação, considera-se uma rapper militante e é conhecida pela sua escrita exímia, emotiva e politicamente engajada. Com uma vasta discografia, conta já com um percurso sólido no panorama da música lusófona: duas mixtapes (Capicua Goes Preemo - 2008 e Capicua Goes West - 2013), dois álbuns em nome próprio e um disco de remisturas (Capicua - 2012, Sereia Louca - 2014 e Medusa - 2015), um disco-livro para crianças em parceria com Pedro Geraldes (Mão Verde - 2016) e um disco luso-brasileiro partilhado com Emicida, Rael e Valete (Língua Franca - 2017). Na última década, tem somado intensos e participados concertos, conquistando um público muito diverso e o reconhecimento da crítica, contribuindo sempre para a destruição dos estigmas associados ao Rap no nosso país. Apologista da espontaneidade e cultivando uma clara atitude feminista, tem acumulado colaborações com vários artistas da lusofonia, bem como diversas conferências, workshops e projetos sociais. De assinalar é também o seu aclamado percurso como letrista e a sua actividade como cronista na Revista Visão. O ano de 2020 começa com novo álbum (Madrepérola) e os olhos postos na estrada, onde espera poder consumar o disco muitas vezes.

\section{José Soeiro}

Sociólogo. Doutorado pela Faculdade de Economia da Universidade de Coimbra, na área da sociologia do trabalho e da ação coletiva. É deputado à Assembleia da República. É coautor, entre outros, dos livros: Cuidar de quem Cuida (Objectiva, 2020, com Mafalda Araújo e Sofia Figueiredo), The Routledge Companion to Theatre of the Oppressed (Routledge, 2019, com Kelly Howe e Julian Boal), A Falácia do Empreendedorismo (Bertrand, 2016, com Adriano Campos), Não Acredite em Tudo o que Pensa (Tinta-da-China, 2013, com Miguel Cardina e Nuno Serra).

\section{Lígia Fero}

Lígia Ferro é investigadora do Instituto de Sociologia da Universidade do Porto e professora auxiliar do Departamento de Sociologia da Faculdade de Letras da Universidade do Porto. Os seus últimos trabalhos de investigação têm focalizado práticas culturais, educação artística, migrações, integração socioprofissional e investigação-ação, especialmente em contextos urbanos. Atualmente faz parte da direção da Associação Portuguesa de Sociologia e é Vice-Presidente da Associação Europeia de Sociologia. 


\section{CADERNOS DAPANDEMIA $\underbrace{\text { SNSTITUTODE }}_{\text {OUPORTO }}$ SOCIOLOGIA}

\section{Pedro Quintela}

Sociólogo, investigador e consultor. Licenciado em Sociologia pelo ISCTE-IUL, mestre em Cidades e Culturas Urbanas pela Faculdade de Economia da Universidade de Coimbra (FEUC), onde actualmente realiza o seu projecto de doutoramento em Sociologia sobre trabalho criativo em design gráfico e de comunicação em Portugal, em fase de conclusão, tendo como Entidade Acolhedora o Centro de Estudos Social (CES) da Universidade de Coimbra. Tem integrado, como investigador, alguns projectos de pesquisa científica, centrados sobretudo no domínio da sociologia das artes e da cultura. Os seus interesses de investigação académica centram-se em diferentes domínios relacionados com as cidades, os projetos e políticas culturais, as culturas urbanas e a economia cultural e criativa (especialmente no domínio do trabalho). Participa ainda, com alguma regularidade, em encontros científicos, nacionais e internacionais, relacionados com estas temáticas de investigação, sobre as quais tem também publicado. Paralelamente, desenvolve trabalho de consultoria técnica, enquanto quadro permanente da Quaternaire Portugal, SA onde integra equipas que desenvolvem estudos e projectos nas áreas dos projectos e políticas culturais, do planeamento estratégico, dos projectos e políticas urbanas, entre outras.

\section{Regina Guimarães}

Regina Guimarães (Porto, 1957). A par da prática da Poesia tem trabalhado nas áreas do Teatro, da Tradução, da Canção, da Dramaturgia, da Educação pela Arte, da Crítica, do Vídeo, do Argumento, da Produção. Foi docente na FLUP, na ESMAE, na ESAD. Foi directora da revista A Grande Ilusão, presidente da Associação Os Filhos de Lumière, programadora do ciclo permanente O Sabor do Cinema no Museu de Serralves e integrou a equipa do Nove e Meia, cineclube nómada. É co-fundadora do Centro Mário Dionísio. Com Ana Deus, desenvolveu o projecto musical Três Tristes Tigres, entre outras aventuras. Realizou inúmeras experiências em torno da palavra. Organiza desde 2007 a Leitura Furiosa. Tem orientado oficinas de escrita e de iniciação ao cinema. Vive e trabalha com Saguenail desde 1975. Hélastre é o signo da sua obra comum.

\section{Tânia Leão}

Socióloga e investigadora. Mestre em Comunicação, Cultura e Tecnologias de Investigação pelo ISCTE-IUL e doutorada em Sociologia com especialização em Cidades e Culturas Urbanas pela Faculdade de Economia da Universidade de Coimbra (FEUC). Os projetos de mestrado e de doutoramento que desenvolveu centraram-se no estudo de festivais de cinema nacionais, com particular enfoque nos públicos. Iniciou a carreira de investigação no extinto Observatório das Atividades Culturais (OAC), e é, atualmente, investigadora integrada do Instituto de Sociologia da Universidade do Porto, onde inclui o subgrupo de investigação em "Criação Artística, Práticas e Políticas Culturais". É, ainda, investigadora principal no Observatório Social de Vila Nova de Gaia. Os seus interesses de investigação recaem nas áreas da cultura e artes, em especial o cinema e artes visuais, consumos e práticas culturais, políticas culturais, trabalho cultural, educação e metodologias qualitativas. É autora e coautora de várias publicações nestes domínios. Colabora frequentemente com festivais e mostras de cinema, sua área de investigação preferencial. É membro da Associação de Investigadores da Imagem em Movimento (AIM) e da European Network for Cinema and Media Studies (NECS). E-mail: tsilva@letras. up.pt.

\section{Teresa Martinho}

Teresa Duarte Martinho é investigadora no Instituto de Ciências Sociais da Universidade de Lisboa (ICS-ULisboa), especializada no estudo do sector cultural e das consequências do processo de digitalização na cultura. Foi investigadora no Observatório das Actividades Culturais (1996-2013) de 


\section{CADERNOS DAPANDEMIA SOCIOLOCI}

1996 a 2011, tendo estudado, entre outros temas, as políticas culturais e as condições das profissões artísticas e culturais em diversos domínios, do cinema e audiovisual aos museus e às bibliotecas, passando pela edição de livros e pelas artes visuais. É licenciada e doutorada em sociologia, pelo ISCTE-Instituto Universitário de Lisboa. Trabalhou como jornalista, principalmente nas áreas das artes e da cultura, entre 1990 e 1996. Ensina, desde 2016, Introdução às Ciências Sociais na Faculdade de Ciências Humanas da Universidade Católica Portuguesa. Foi co-organizadora do livro Cultura e Digital em Portugal (2016, Afrontamento). Publicou, entre outros textos, Apresentar a Arte. Estudo sobre monitores de visitas a exposições (2007, Observatório das Actividades Culturais), Mediadores culturais em Portugal: perfis e trajetórias de um novo grupo ocupacional (2013, Análise Social) e Researching culture through big data: computational engineering and the human and social sciences (2018, Social Sciences); como co-autora: As Politicas Culturais em Portugal (1998, Observatório das Actividades Culturais), O Mundo da Arte Jovem. Protagonistas, lugares e lógicas de acção (2003, Celta), Mapping cultural policy in Portugal: From incentives to crisis (2018, International Journal of Cultural Policy) e O Choque Tecno-liberal, os Media e o Jornalismo (2020, Almedina). Integra a equipa de investigação do Inquérito às Práticas Culturais dos Portugueses, promovido pela Fundação Calouste Gulbenkian em parceria com o ICS-ULisboa.

\section{Vânia Rodrigues}

Vânia Rodrigues (Porto, 1979). Gestora Cultural, investigadora e consultora nas áreas de planeamento estratégico, programação e gestão cultural, desenho de projectos e parcerias internacionais. Licenciada em Estudos Europeus (FLUP) e Mestre em Políticas Culturais e Gestão Cultural pela City University of London (2009). Prepara actualmente tese de doutoramento em Estudos Artísticos, na Universidade de Coimbra, sob o tema "MODUS OPERANDI - A nova ecologia de produção, gestão e criação nas artes performativas."
É Investigadora-Colaboradora do CEIS2O/UC. No passado, foi responsável pela estratégia, gestão e circulação internacional da companhia mala voadora, e pela co-programação do espaço próprio da companhia (2013-2018). Foi Assessora Estratégica da Artemrede (2014-2017), tendo conduzido os trabalhos de elaboração do seu "Plano Estratégico e Operacional 2015-2020" e co-coordenado a conferência internacional e a edição do livro 'Políticas Culturais para o Desenvolvimento'. Exerceu funções de coordenação na Setepés-projectos artístico-culturais, tendo sido consultora de projectos culturais para várias organizações portuguesas, entre elas a EGEAC e o TNDMII em Lisboa ou o CCVF, em Guimarães. Participa em diversas redes internacionais do sector cultural e criativo e é membro convidado do Conselho Municipal de Cultura do Porto (até Fev. 2020) e do Conselho Consultivo da Artemrede. Em 2020, publica "AS PRODUTORAS - Produção e Gestão Cultural em Portugal. Trajectos Profissionais (1990-2019)", ed. Caleidoscópio.

\section{Vera Borges}

Licenciada em Sociologia (FCSH), Mestre em Comunicação e Cultura e Tecnologias da Informação (ISCTE) e, desde 2005, doutorada em Sociologia, especialidade Cultura, pela EHESS (Paris) e pela FCSH-UNL, com uma tese sobre o mundo do teatro em Portugal, sob a direção de Pierre-Michel Menger. É investigadora integrada do CIES-Iscte. Colabora como docente convidada em Políticas Públicas para a Cultura e Gestão de Projetos Artísticos, no Mestrado em Estudos de Teatro, da Faculdade de Letras da Universidade de Lisboa. Desenvolve investigação na área das profissões, organizações e mercados de trabalho artísticos. Integra a equipa do Inquérito Nacional às Práticas Culturais dos Portugueses (FCG e ICS-UL). É autora e co-autora de livros e artigos sobre o teatro em Portugal, dos quais se destaca: Criatividade e Instituições (ICS, 2012), Mapping culture in Portugal (International Journal of Cultural Policy, 2016), Emerging patterns of artistic organizations in Portugal (Sociologie del Lavoro, 2020). E-mail: vera.borges@iscte-iul.pt. 
